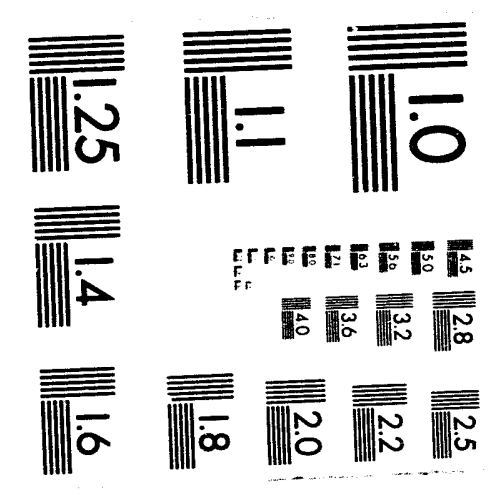



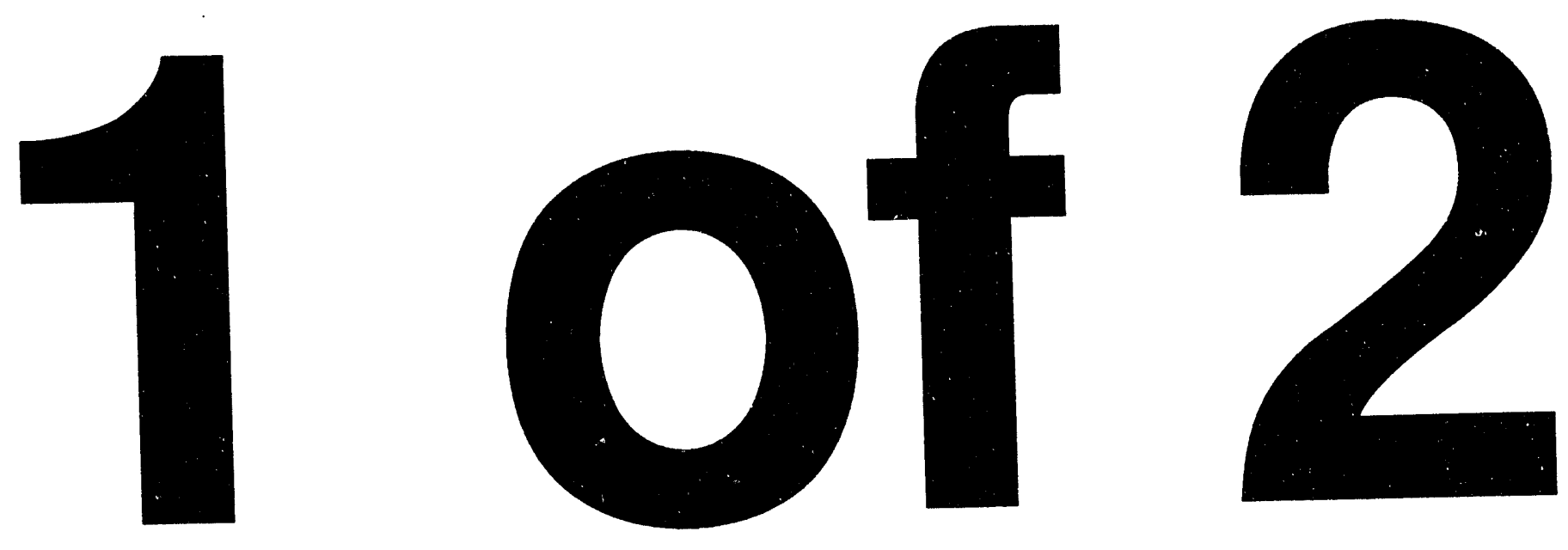


\title{
Approximation Functions for Airblast Environments From Buried Charges
}

\author{
H. Reichenbach \\ K. Behrens \\ Fraunhofer-Institut für Kurzzeitdynamik \\ Ernst-Mach-Institut \\ Freiburg, Germany
}

A. L. Kuhl

Lawrence Livermore National Laboratory

El Segundo, CA, USA

Contract No. DNA 001-91-C-0039

This work was sponsored by the Defense Nuclear Agency

under RDT \& E RMSS Code B 4662 D RA RG 003524400 A AC

Work performed under the auspices of the U.S. Department of Energy by the Lawrence Livermore National Laboratory under contract number W-7405-ENG-48 and DNA IACRO number 92-824 and Work Unit 00001.

Prepared for

Director Nuclear Agency

Washington, DC 20305-1000

This Document consists of 105 Pages 


\section{SUMMARY}

In EMI report E 1/93, "Airbiast Environments from Buried HE-Charges", fit functions were used for the compact description of blastwave parameters. The coefficients of these functions were approximated by means of second order polynomials versus DOB. In most cases, the agreement with the measured data was satisfactory; to reduce remaining noticeable deviations, an approximation by polygons (i.e., piecewise-linear approximation) was used instead of polynomials.

The present report describes the results of the polygon approximation and compares them to previous data. We conclude that the polygon representation leads to a better agreement with the measured data. 


\section{TABLE OF CONTENTS}

Section

Summary

i

Figures

iii

Tables

1 INTRODUCTION

2 AIR BLAST FUNCTION

2.1 Peak Overpressure

2.1.1 Fit Functions

3

2.1.2 Overpressure-Range Curves

2.1.3 Estimation of Energy Absorption by Cratering Processes

5

2.1.4 Isobaric DOB Curves

2.2 Overpressure Impulses

2.2.1 Fit Functions

2.2.2 Impulse-Range Curves

2.2.3 Iso-Impulse DOB Curves

2.3 Arrival Times

2.3.1 Fit Functions

2.3.2 Arrival-Time Range Curves

2.3.3 Constant Arrival DOB Curves

2.4 Positive Phase Durations

2.4.1 Fit Function

2.4.2 Duration-Range Curves 14

2.4.3 Constant Duration Curves 


\section{FIGURES}

Figure

Page

1 Coefficients of approximation functions for peak overpressure vs ground range at different DOB.

Aerated grout (dry YTONG)

polynomial and polygon approximation

2 Coefficients of approximation functions for peak overpressure vs ground range at different DOB.

Water-saturated grout (wet YTONG)

polynomial and polygon approximation

3 Coefficients of approximation functions for peak overpressure vs ground range at different DOB.

Wet clay/loam

polynomial and polygon approximation

4 Peak overpressure vs ground range curves for different DOB Aerated grout (dry YTONG)
(a) polygon approximation
(b) polynomial approximation

5 Peak overpressure vs ground range curves for different DOB Water-saturated grout (wet YTONG)
(a) polygon approximation
(b) polynomial approximation

6 Peak overpressure vs ground range curves for different DOB Wet clay/loarn
(a) polygon approximation
(b) polynomial approximation

7a Percentage of energy losses vs ground range

Soil material: dry aerated grout (dry YTONG)

Polygon approximation

$7 \mathrm{~b}$ Percentage of energy losses vs ground range

Soil material: $d r y$ aerated grout (dry YTONG)

Polynomial approximation

8a Percentage of energy losses vs ground range

Soil material: water-saturated grout (wet YTONG)

Polygon approximation

$8 \mathrm{~b}$ Percentage of energy losses vs ground range

Soil material: water-saturated grout (wet YTONG)

Polynomial approximation

9a Percentage of energy losses vs ground range

Soil material: clay/loam

Polygon approximation

9b Percentage of energy losses vs ground range

Soil material: clay/loam

Polynomial approximation 


\section{FIGURES (Continued)}

Figure

Page

10a Percentage of energy losses vs DOB at $G R=2\left[\mathrm{~m} / \mathrm{kg}^{1 / 3}\right]$

Polygon approximation

10b Percentage of energy losses vs DOB at $G R=2\left[\mathrm{~m} / \mathrm{kg}^{1 / 3}\right]$

Polynomial approximation

1 la Percentage of energy losses vs DOB at $G R=6\left[\mathrm{~m} / \mathrm{kg}^{1 / 3}\right]$

Polygon approximation

$11 \mathrm{~b}$ Percentage of energy losses vs DOB at $G R=6\left[\mathrm{~m} / \mathrm{kg}^{1 / 3}\right]$

Polynomial approximation

12a Percentage of energy losses vs DOB at $G R=10\left[\mathrm{~m} / \mathrm{kg}^{1 / 3}\right]$ Polygon approximation

12b Percentage of energy losses vs DOB at $G R=10\left[\mathrm{~m} / \mathrm{kg}^{1 / 3}\right] \mathrm{L}$.

Polynomial approximation

13a Isobaric DOB curves for dry aerated grout (dry YTONG) in the intermediate-pressure regime. Spline function approximation

13b Isobaric DOB curves for dry aerated grout (dry YTONG) in the intermediate-pressure regime. Polygon approximation

13c Isobaric DOB curves for dry aerated grout (dry YTONG) in the intermediate-pressure regime. Polynomial approximation

14a Isobaric DOB curves for water-saturated grout (wet YTONG) in the intermediate-pressure regime. Spline function approximation

14b Isobaric DOB curves for water-saturated grout (wet YTONG) in the intermediate-pressure regime. Polygon approximation

14c Isobaric DOB curves for water-saturated grout (wet YTONG) in the intermediate-pressure regime. Polynomial approximation.

15a Isobaric DOB curves for wet clay/loam in the intermediate-pressure regime. Spline function approximation

$15 \mathrm{~b}$ Isobaric DOB curves for wet clay/loam in the intermediate-pressure regime. Polygon approximation

15c Isobaric DOB curves for wet clay/loam in the intermediate-pressure regime. Polynomial approximation

16a Isobaric DOB curves for dry aerated grout (dry YTONG) in the low-pressure regime. Spline function approximation 


\section{FIGURES (continued)}

Figure

Page

$16 \mathrm{~b}$ Isobaric DOB curves for dry aerated grout (dry YTONG) in the low-pressure regime. Polygon approximation

16c Isobaric DOB curves for dry aerated grout (dry YTONG) in the low-pressure regime. Polynomial approximation

17a Isobaric DOB curves for water-saturated grout (wet YTONG) in the low-pressure regime. Spline function approximation

$17 \mathrm{~b}$ Isobaric DOB curves for water-saturated grout (wet YTONG) in the low-pressure regime. Polygon approximation

17c Isobaric DOB curves for water-saturated grout (wet YTONG) in the low-pressure regime. Polynomial approximation

18a Isobaric DOB curves for wet clay/loam in the low-pressure regime. Spline function approximation

$18 \mathrm{~b}$ Isobaric DOB curves for wet cluy/loam in the low-pressure regime. Polygon approximation

18c Isobaric DOB curves for wet clay/loam in the low-pressure regime. Polynomial approximation

19 Coefficients of approximation functions for overpressure impulse vs ground range at different DOB.

Aerated grout (dry YTONG); polynomial and polygon approximation

20 Coefficients of approximation functions for overpressure impulse vs ground range at different DOB.

Water-saturated grout (wet YTONG)

polynomial and polygon approximation

21 Coefficients of approximation functions for overpressure impulse vs ground range at different DOB.

Wet clay/loam; polynomial and polygon approximation

22 Overpressure-impulse vs ground-range curves for different DOB.

Aerated grout (dry YTONG)
(a) polygon approximation
(b) polynomial approximation

23 Overpressure-impulse vs ground-range curves for different DOB.

Water-saturated grout (wet YTONG)
(a) polygon approximation
(b) polynomial approximation

24 Overpressure-impulse vs ground-range curves for different DOB.

Wet clay/loam
(a) polygon approximation
(b) polynomial approximation 


\section{FIGURES (Continued)}

Figure

Page

25a Iso-impulse DOB curves for dry aerated grout (dry YTONG).

Spline function approximation

25b Iso-impulse DOB curves for dry aerated grout (dry YTONG).

Polygon approximation

25c Iso-impulse DOB curves for dry aerated grout (dry YTONG).

60

Polynomial approximation

26a Iso-impulse DOB curves for water-saturated grout (wet YTONG)

61

Spline function approximation

26b Iso-impulse DOB curves for water-saturated grout (wet YTONG)

62

Polygon approximation

26c Iso-impulse DOB curves for water-saturated grout (wet YTONG)

63

Polynomial approximation

27a Iso-impulse DOB curves for wet clay/loam.

Spline function approximation

27b Iso-impulse DOB curves for wet clay/loam.

65

Polygon approximation

27c Iso-impulse DOB curves for wet clay/loam.

Polynomial approximation

28 Coefficients of approximation functions for arrival time vs ground range at different DOB.

Aerated grout (dry YTONG); polynomial and polygon approximation

29 Coefficients of approximation functions for arrival time vs ground range at different $\mathrm{DOB}$.

Water-saturated grout (wet YTONG);

polynomial and polygon approximation

30 Coefficients of approximation functions for arrival time vs ground range at different $\mathrm{DOB}$.

Wet clay/loam; polynomial and polygon approximation

31 Arrival-time vs ground-range curves for different DOB.

Aerated grout (dry YTONG)
(a) polygon approximation
(b) polynomial approximation

32 Arrival-time vs ground-range curves for different DOB. Water-saturated grout (wet YTONG)
(a) polygon approximation
(b) polynomial approximation

33 Arrival-time vs ground-range curves for different DOB. Wet clay/loam
(a) polygon approximation
(b) polynomial approximation 


\section{FIGURES (Continued)}

Figure

Page

34a Constant arrival time DOB curves for dry aerated grout (dry YTONG)

Spline function approximation

34b Constant arrival time DOB curves for dry aerated grout (dry YTONG) Polygon approximation

34c Constant arrival time DOB curves for dry aerated grout (dry YTONG) Polynomial approximation

35a Constant arrival time DOB curves for water-saturated grout

(wet YTONG)

Spline function approximation

35b Constant arrival time DOB curves for water-saturated grout (wet YTONG)

Polygon approximation

$35 \mathrm{c}$ Constant arrival time DOB curves for water-saturated grout (wet YTONG)

Polynomial approximation

36a Constant arrival time DOB curves for wet clay/loam Spline function approximation

36b Constant arrival time DOB curves for wet clay/loam

Polygon approximation

36c Constant arrival time DOB curves for wet clay/loam

Polynomial approximation

37 Coefficients of approximation functions for positive phase duration vs

ground range at different $\mathrm{DOB}$.

Aerated grout (dry YTONG); polynomial and polygon approximation

38 Coefficients of approximation functions for positive phase duration vs

ground range at different DOB.

Water-saturated grout (wet YTONG);

polynomial and polygon approximation

39 Coefficients of approximation functions for positive phase duration vs ground range at different $\mathrm{DOB}$.

Wet clay/loam; polynomial and polygon approximation

40 Positive phase duration vs ground range curves for different DOB.

Aerated grout (dry YTONG)
(a) polygon approximation
(b) polynomial approximation

41 Positive phase duration vs ground range curves for different DOB. Watci-saturated grout (wet YTONG)
(a) polygon approximation
(b) polynomial approximation 


\section{FIGURES (Continued)}

Figure

Page

42 Positive phase duration vs ground range curves for different DOB.

Wet clay/loam;
(a) polygon approximation
(b) polynomial approximation

43a Constant duration DOB curves for dry aerated grout (dry iTONG) Spline function approximation Polynomial approximation

43c Constant duration DOB curves for dry aerated grout (dry YTONG) Polygon approximation

44a Constant duration DOB curves for water-saturated grout (wet YTONG) Spline function approximation

44b Constant duration DOB curves for water-saturated grout (wet YTONG) Polygon approximation

44c Constant duration DOB curves for water-saturated grout (wet YTONG) Polynomial approximation

45a Constant duration DOB curves for clay/loam Spline function approximation

Polygon approximation

45c Constant duration DOB curves for clay/loam

Polynomial approximation 


\section{SECTION 1}

\section{INTRODUCTION}

In the Ernst-Mach-Institut report E $1 / 93$ entitled "Airblast Environments from Buried HE Charges", fit functions in dependence of the ground range (GR) and the depth of burst (DOB) were given for the following airblast parameters: peak overpressure, overpressure impulse, arrival time, positive phase duration. For the measured data, $y$, approximations of the form

$(\mathrm{Eq} \cdot 1)$

$$
\log y=\sum_{i=0}^{3} K_{i}(\log G R)^{i}
$$

were used while polynomials of the form

$$
K_{i}=\sum_{j=0}^{3} k_{j i} D O B^{j}
$$

were chosen for the coefficients $K_{i}$. Scaled values were used for $G R$ as well as for $D O B$, i.e., $[\mathrm{GR}]=\mathrm{m} / \mathrm{kg}^{1 / 3}$ and $[D O B]=\mathrm{m} / \mathrm{kg}^{1 / 3}$.

As an improvement, the following function has been chosen as approximation for the airblast parameter "arrival time" instead of equation (Eq 1):

(Eq. 3)

$$
t_{a}=c_{1} \cdot \log G R+c_{2} / G R+G R / c_{0}+c_{3},
$$

where $\mathrm{c}_{0}=$ sound velocity $[\mathrm{m} / \mathrm{s}]$.

The approximation of the coefficients $c_{i}(i=1,2,3)$ was made by means of the polynomials defined in (Eq 2).

In general, this choice of fit functions leads to a satisfactory agreement with the measured data. Digressions, however, have been noticed that can have various causes, some of which are: 
(a) material-dependent dispersion of the characteristics of the soil material,

(b) variations in the charge weight and of $\mathrm{DOB}$,

(c) limited accuracy of the measured values,

(d) the degree of the approximation function is not sufficient,

(e) the approximation of the coefficients in the form of polynoms is not sufficient.

The causes given in (a) - (c) are of experimental nature and cannot be changed later, whereas consequences on the propagation functions and $D O B$ curves can be noticed when there is a change in the approximation.

To do this, another description of the coefficients according to (Eq 2) was made and the propagation functions and the DOB curves were re-evaluated. The aim was to evaluate whether the deviations were caused by the choice of approximations.

Details of the DOB experiments with $0.5-\mathrm{g}$ Nitropenta charges in three different simulated soils and the kind of data may be found in the before-mentioned EMI report E 1/93. 


\section{SECTION 2}

\section{AIRBLAST FUNCTION}

No changes were made to the form of the approximation function $\mathrm{Eq} 1$, as a very exact approximation of the blast wave data could be observed at least in the blast wave region. Noticeable deviations, however, were found for the description of the coefficients $\mathrm{K}_{\mathrm{i}}(\mathrm{Eq} 2)$ as function of DOB by polynomials. Efforts were made to obtain a better approach by means of polygons, i.e., piecewise linear approximations.

\subsection{PEAK OVERPRESSURE}

\subsubsection{Fit Functions}

As fit functions for measured peak overpressure, expressions of the form

$$
\begin{aligned}
\log p & =a_{0}+a_{1} \log (G R)+a_{2}(\log (G R))^{2} \\
1 & \leq G R\left[\mathrm{~m} / \mathrm{kg}^{1 / 3}\right] \leq 10
\end{aligned}
$$

were used.

The values of the coefficients $a_{i}(i=0,1,2)$ as function of DOB [cm] are shown in Figures 1 in 3 . The coefficients obtained from the individual experiments are indicated (dots). For a comparison with the polygon approximation (solid lines), the corresponding polynomial curves (dotted lines) are also given.

The deviations of the experimental values from the polygon curves are lower than in the case of the polynomial approximation. The analytical description of the polygons for each coefficient is given in Table 1 . The range of validity applies to the interval:

$$
\begin{aligned}
-0.25 & \leq \mathrm{DOB}\left[\mathrm{m} / \mathrm{kg}^{1 / 3}\right] \leq 0.63 \\
-2 & \leq \mathrm{DOB}[\mathrm{cm}] \leq 5.0
\end{aligned}
$$

The corresponding data for the polynomial presentation are to be found in report E 1/93, page 17 . 


\begin{tabular}{|c|c|c|c|c|c|c|c|c|c|}
\hline AO & $\begin{array}{l}= \\
= \\
=\end{array}$ & $\begin{array}{l}1.3469 \\
1.0423 \\
0.4697\end{array}$ & $\begin{array}{l}+0.1016 \\
-6.8060 \\
-\quad 3.0184\end{array}$ & $\begin{array}{l}\text { * DOB } \\
\text { * DOB } \\
\text { * DOB }\end{array}$ & $\begin{array}{l}-0.25 \\
-0.04 \\
+0.15\end{array}$ & $\begin{array}{l}<= \\
<= \\
<=\end{array}$ & $\begin{array}{l}\text { DOB } \\
\text { DOB } \\
\text { DOB }\end{array}$ & $\begin{array}{l}< \\
< \\
<\end{array}$ & $\begin{array}{l}-0.04 \\
+0.15 \\
+0.63\end{array}$ \\
\hline AI & $\begin{array}{l}= \\
= \\
=\end{array}$ & $\begin{array}{l}-3.3272 \\
-2.6681 \\
-0.7358\end{array}$ & $\begin{array}{r}-2.1747 \\
+2.7706 \\
-0.0102\end{array}$ & $\begin{array}{l}\text { * DOB } \\
\text { * DOB } \\
\text { * DOB }\end{array}$ & $\begin{array}{l}-0.25 \\
-0.04 \\
+0.15\end{array}$ & $\begin{array}{l}<= \\
<= \\
<=\end{array}$ & $\begin{array}{l}\text { DOB } \\
\text { DOB } \\
\text { DOB }\end{array}$ & $\begin{array}{l}< \\
< \\
<\end{array}$ & $\begin{array}{l}-0.0 \\
+0.1 \\
+0.6\end{array}$ \\
\hline A2 & $\begin{array}{l}= \\
=\end{array}$ & $\begin{array}{r}1.1827 \\
0.7881 \\
-0.3182\end{array}$ & $\begin{array}{l}+1.9152 \\
-7.0330 \\
+0.2841\end{array}$ & $\begin{array}{l}\text { * DOB } \\
\text { * DOB } \\
\text { * DOB }\end{array}$ & $\begin{array}{l}-0.25 \\
-0.04 \\
+0.15\end{array}$ & $\begin{array}{l}<= \\
<= \\
<=\end{array}$ & $\begin{array}{l}\text { DOB } \\
\text { DOB } \\
\text { DOB }\end{array}$ & $\begin{array}{l}< \\
<\end{array}$ & $\begin{array}{l}-0.0 \\
+0.1 \\
+0.6\end{array}$ \\
\hline
\end{tabular}

Water Saturated Grout ( wet YTONG )

\begin{tabular}{|c|c|c|c|c|c|c|c|c|c|}
\hline AO & $\begin{array}{l}= \\
= \\
=\end{array}$ & $\begin{array}{l}1.4473 \\
0.8340 \\
0.0338\end{array}$ & $\begin{array}{r}0.4429 \\
-7.6695 \\
-2.7843\end{array}$ & $\begin{array}{l}\text { * DOB } \\
\text { * DOB } \\
\text { * DOB }\end{array}$ & $\begin{array}{l}-0.25 \\
-0.08 \\
+0.16\end{array}$ & $\begin{array}{l}<= \\
<= \\
<=\end{array}$ & $\begin{array}{l}\text { DOB } \\
\text { DOB } \\
\text { DOB }\end{array}$ & $\begin{array}{l}< \\
< \\
<\end{array}$ & $\begin{array}{l}-0.08 \\
+0.16 \\
+0.63\end{array}$ \\
\hline 1 & $\begin{array}{l}= \\
= \\
=\end{array}$ & $\begin{array}{l}-3.3473 \\
-2.3183 \\
-0.4856\end{array}$ & $\begin{array}{r}-2.2962 \\
+1.3158 \\
+0.1262\end{array}$ & $\begin{array}{l}\text { * DOB } \\
\text { * DOB } \\
\text { * DOB }\end{array}$ & $\begin{array}{l}-0.25 \\
-0.08 \\
+0.16\end{array}$ & $\begin{array}{l}<= \\
<= \\
<=\end{array}$ & $\begin{array}{l}\text { DOB } \\
\text { DOB } \\
\text { DOB }\end{array}$ & $\begin{array}{l}< \\
< \\
<\end{array}$ & $\begin{array}{l}-0.08 \\
+0.16 \\
+0.63\end{array}$ \\
\hline A2 & $\begin{array}{l}= \\
= \\
=\end{array}$ & $\begin{array}{r}1.1350 \\
0.5712 \\
-0.3366\end{array}$ & $\begin{array}{l}+1.8731 \\
-5.5845 \\
-0.0421\end{array}$ & $\begin{array}{l}\text { * DOB } \\
\text { * DOB } \\
\text { * DOB }\end{array}$ & $\begin{array}{l}-0.25 \\
-0.08 \\
+0.16\end{array}$ & $\begin{array}{l}<= \\
<= \\
<=\end{array}$ & $\begin{array}{l}\text { DOB } \\
\text { DOB } \\
\text { DOB }\end{array}$ & $\begin{array}{l}< \\
< \\
<\end{array}$ & $\begin{array}{l}-0.08 \\
+0.16 \\
+0.63\end{array}$ \\
\hline
\end{tabular}

\section{Clay/Loan}

\begin{tabular}{|c|c|c|c|c|c|c|c|c|c|}
\hline AO & $\begin{array}{l}= \\
= \\
=\end{array}$ & $\begin{array}{r}1.3050 \\
0.6046 \\
-0.1763\end{array}$ & $\begin{array}{r}-0.3969 \\
-8.3307 \\
-2.1279\end{array}$ & $\begin{array}{l}\text { * DOB } \\
\text { * DOB } \\
\text { * DOB }\end{array}$ & $\begin{array}{l}-0.25 \\
-0.09 \\
+0.13\end{array}$ & $\begin{array}{l}<= \\
<= \\
<=\end{array}$ & $\begin{array}{l}\text { DOB } \\
\text { DOB } \\
\text { DOB }\end{array}$ & $\begin{array}{l}< \\
<\end{array}$ & $\begin{array}{l}-0.09 \\
+0.13 \\
+0.63\end{array}$ \\
\hline Al & $\begin{array}{l}= \\
= \\
=\end{array}$ & $\begin{array}{l}-2.9136 \\
-1.8388 \\
-0.0442\end{array}$ & $\begin{array}{r}+0.1484 \\
+2.3357 \\
-1.9081\end{array}$ & $\begin{array}{l}\text { * DOB } \\
\text { * DOB } \\
\text { * DOB }\end{array}$ & $\begin{array}{l}-0.25 \\
-0.09 \\
+0.13\end{array}$ & $\begin{array}{l}<= \\
<= \\
<=\end{array}$ & $\begin{array}{l}\text { DOB } \\
\text { DOB } \\
\text { DOB }\end{array}$ & $\begin{array}{l}< \\
<\end{array}$ & $\begin{array}{l}-0.09 \\
+0.13 \\
+0.63\end{array}$ \\
\hline$\lambda ?$ & $\begin{array}{l}= \\
= \\
=\end{array}$ & $\begin{array}{r}0.8448 \\
0.3162 \\
-\quad 0.5459\end{array}$ & $\begin{array}{l}+0.2254 \\
-5.7686 \\
+1.0739\end{array}$ & $\begin{array}{l}\text { * DOB } \\
\text { * DOB } \\
\text { * DOB }\end{array}$ & $\begin{array}{l}-0.25 \\
-0.09 \\
+0.13\end{array}$ & $\begin{array}{l}<= \\
<= \\
<=\end{array}$ & $\begin{array}{l}\text { DOB } \\
\text { DOB } \\
\text { DOB }\end{array}$ & $\begin{array}{l}< \\
<\end{array}$ & $\begin{array}{l}-0.0 \\
+0.1 \\
+0.6\end{array}$ \\
\hline
\end{tabular}

Table 1. Coefficients of approximation functions for peak overpressure vs ground range. DOB dependency described by polygon curves.

$[D O B]=\mathrm{m} / \mathrm{kg}^{1 / 3}$ 


\subsubsection{Overpressure-Range Curves}

The functions presented in Chapter 2.1.1 (Eq. 4 and Table 1) allow to calculate the overpressure-range curves for any DOB in the given interval (Eq. 5). In Figures 4 to 6, some curves for different DOBs are presented not only for polygon but also for polynomial approximation. The curves valid for HOB experiments are shown in color.

It can be noticed that the deviations of the peak overpressures vs ground range curves that are obtained in the described way are within acceptable limits.

\subsubsection{Estimation of Energy Absorption by Cratering Processes}

The estimation of the energy absorption was made according to the schematic in Table 2 . The following result can be found:

(Eq. 6)

$$
\begin{aligned}
& \Delta W / W=1-0.5(G R / R)^{3} \\
& \text { where } p(G R)=p(R)
\end{aligned}
$$

$$
\begin{array}{ll}
G R=\text { ground range (DOB test) } & p(G R)=\text { peak overpressure at GR } \\
R=\text { free air distance } & p(R)=\text { peak overpressure at } R
\end{array}
$$

The function of the free-air overpressure curve is given by

$$
\begin{aligned}
& \log \mathrm{p}=1.047-2.289 * \log \mathrm{R} \\
& \text { for } 0.9<R \leq 2.45 \\
& =0.954-2.253 * \log R+0.427 *\left(\log R^{2}\right) \quad \text { for } 2.45<R \leq 9.8 \\
& \text { where }[R]=\mathrm{m} / \mathrm{kg}^{1 / 3}
\end{aligned}
$$

The fit functions for peak overpressure at DOB tests are defined by Eq. 4 and Table 1.

The percentage of energy losses vs ground range are presented in Figures 7 to 9 for the different soil materials. The results based on polygon approximation are shown in Figures $7 \mathrm{a}$, $8 a, 9 a$, whereas Figures $7 b, 8 b, 9 b$ give the evaluations based on polynomial approximation. 


\section{Table 2}

\section{Evaluation of Energy Absorption}

by Cratering Processes

I Free Air Pressure-Range Function

$$
\begin{array}{ll}
p_{f}=f\left(R / w^{1 / 3}\right) \quad & p_{f}=\text { peak overpressure } \\
& R=\text { distance from charge center } \\
& w=\text { charge weight }
\end{array}
$$

II DOB Pressure-Range Function

$$
\begin{array}{ll}
p_{S}=g_{i}\left(G R / w^{1 / 3} ; D O B / w^{1 / 3}\right) & G R=\text { ground range } \\
& D O B=\text { depth of burst }
\end{array}
$$

III 2W-Assumption for Ideal Surface Bursts

$p_{\text {SO }}=g_{0}\left(G R_{0} / w^{1 / 3} ; 0\right)=f\left(R_{2} /(2 w)^{1 / 3}\right)$ where $G R_{0}=R_{2}$

Conclusion: from $\mathrm{l}: \mathrm{p}_{\mathrm{f}}=$ const if $\mathrm{R} / \mathrm{W}_{1 / 3}=$ const, or

$$
R_{2} /(2 w)^{1 / 3}=R / w^{1 / 3} \quad \underline{\underline{R}=R_{2} / 2^{1 / 3}=G R_{0} / 2^{1 / 3}}
$$

IV Equivalent Surface Burst Assumption

$p_{s}=g_{i}\left(G R / w^{1 / 3} ; D O B / w^{1 / 3}\right)=g_{0}\left(G R_{0} /(w-\Delta w)^{1 / 3} ; 0\right)$ where $G R=G R_{0}$

$\checkmark$ Evaluation of Energy Absorption

(Cranz-Hopkinson Similarity Law)

$R: w^{1 / 3}=G R_{0} / 2^{1 / 3}:\left(w-\Delta w^{1 / 3} \quad\right.$ where $p_{f}=p_{s}$

Conclusion: $\quad G R^{3} / 2 R^{3}=1-\Delta w / w$

$$
\Delta w / w=1-0.5 \cdot(G R / R)^{3} \text { where } p(G R)=p(R)
$$

Table 2. Evaluation of energy absorption by cratering processes. 
The general statements made in report E 1/93 are confirmed. The energy loss based on the peak blast wave pressure is not constant, it varies with ground range. This indicates that, in the DOB tests, the peak pressure at a constant distance from ground zero is not uniformly distributed in space.

It is obvious as demonstrated by Figures 7 to 9 that the estimated energy losses due to cratering processes depends very sensitively on small errors of the approximatively calculated peak overpressures, $p(G R)$, especially in the $H O B$ region. To estimate $\Delta w / w$, the third power of the corresponding distances, $R$, are to insert in equation, Eq. 6 . Therefore, small variations in $\mathrm{R}$ give rise to big changes of the energy losses.

Because the polygon approximation is more accurate than the polynomial one - as we know the diagrams for polygon approximation are more trustworthy. Some negative $\Delta w / w$-values, found for polynomial approximation in the HOB region, are criticized for that reason as questionable.

For different ground range positions, the percentage of energy losses is given as function of $\mathrm{DOB}$ in Figures 10 to 12. For each soil material, two diagrams are shown, based on polygon and polynomial approximations of the overpressure-range curves.

For reasons discussed before, negative $\Delta w / w$-values at polynomial approximation, Figures $10 \mathrm{~b}$ to $12 \mathrm{~b}$, are believed to be questionable.

\subsubsection{Isobaric DOB Curves}

In Figures 13 - 15, isobaric curves for the different soil materials are given in the intermediate-pressure regime. For comparison reasons, the isobaric curves in Figure 13a are shown as spline functions of the values derived from the measured overpressure-ground range curves. In Figure 13b, the isobaric DOB curves are presented as a result of the polygonal approximation whereas Figure $13 \mathrm{c}$ gives the result of the polynomial approximation. The same sequence is used also for the following isobaric curves. The diagrams in the low-pressure regime are presented in Figures 16 to 18.

In comparison to the diagrams with spline functions, the DOB curves were smoothed by the applied coefficient approximations, as expected. The polygonal approximation causes also the appearance of kinks in the DOB curves. Nevertheless, this approximation leads to a result 
that seems more trustworthy than the polynowial approximation. The restriction has to be made here as well (compare E 1/93, page 20) that the isobaric DOB curves are, strictly speaking, only valid in the blast wave regime.

\subsection{OVERPRESSURE IMPULSES}

\subsubsection{Fit Functions}

As fit functions for the recorded overpressure impulses, relations of the form

(Eq. 8)

$$
\begin{aligned}
\log I+=b_{0} & +b_{1} * \log G R+b_{2} *(\log G R)^{2} \\
1 & \leq G R\left[\mathrm{~m} / \mathrm{kg}^{1 / 3}\right] \leq 10
\end{aligned}
$$

were used.

The values of the coefficients $b_{i}(i=0,1,2)$ as function of DOB [cm] are shown in Figures 19 to 21. In addition to the data derived from each experiment (dots), the polygon (solid lines) and the polynomial (dotted lines) approximations are given. The analytical description for polygon curves can be found in Table 3. The range of validity applies to the interval:

(Eq. 9)

$$
\begin{gathered}
-0.25 \leq \mathrm{DOB}\left[\mathrm{m} / \mathrm{kg}^{1 / 3} \leq 0.63\right. \\
-2.0 \leq \mathrm{DOB}[\mathrm{cm}] \leq 5.0
\end{gathered}
$$

The corresponding data for the polynomial presentation are given in report E 1/93, page 21 .

\subsubsection{Impulse-Range Curves}

The functions presented in Chapter 2.2.1 (Eq. 8 and Table 3) allow to calculate the overpressure-impulse vs ground-range curves for any DOB in the given interval (Eq. 9). In Figures 22 to 24 , some curves for different DOBs are plotted not only for polygon but also for polynomial approximations.

The deviation of the two sets of diagrams for the different soil materials remains in an acceptable range and exceeds $25 \%$ only in a few cases. 


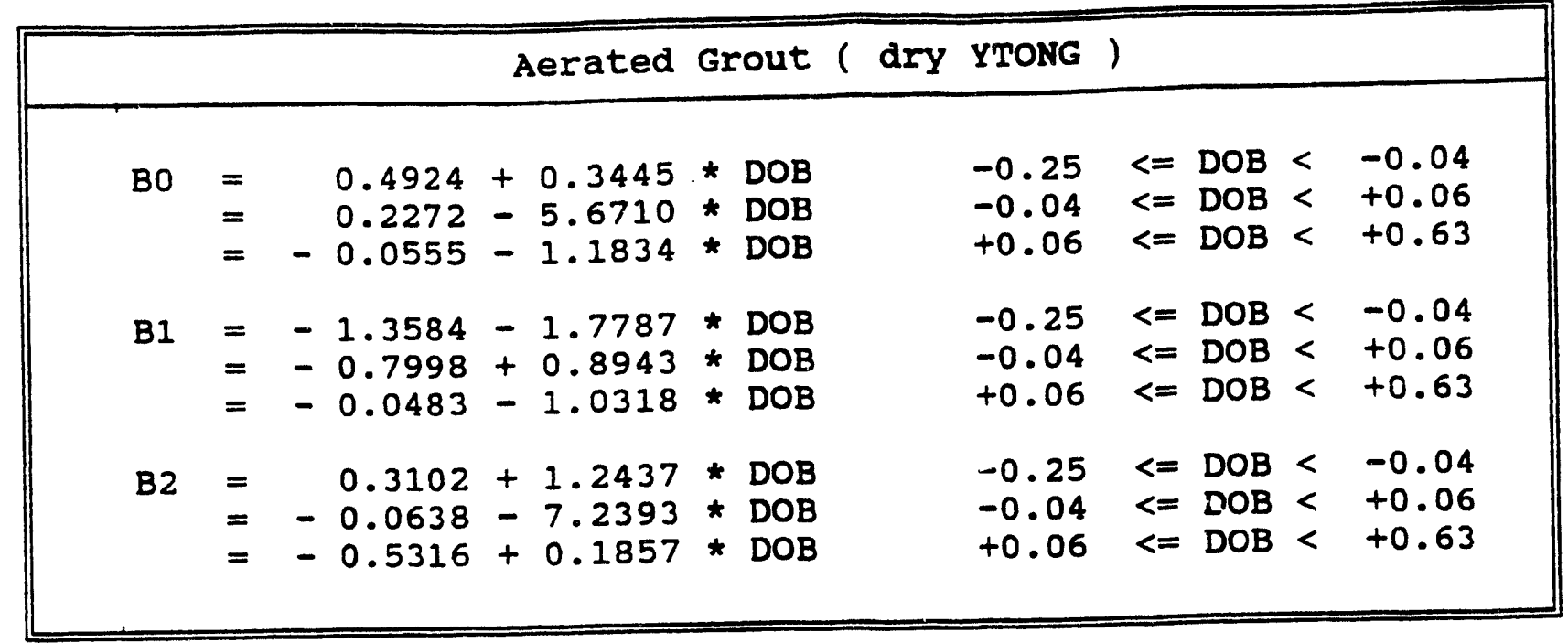

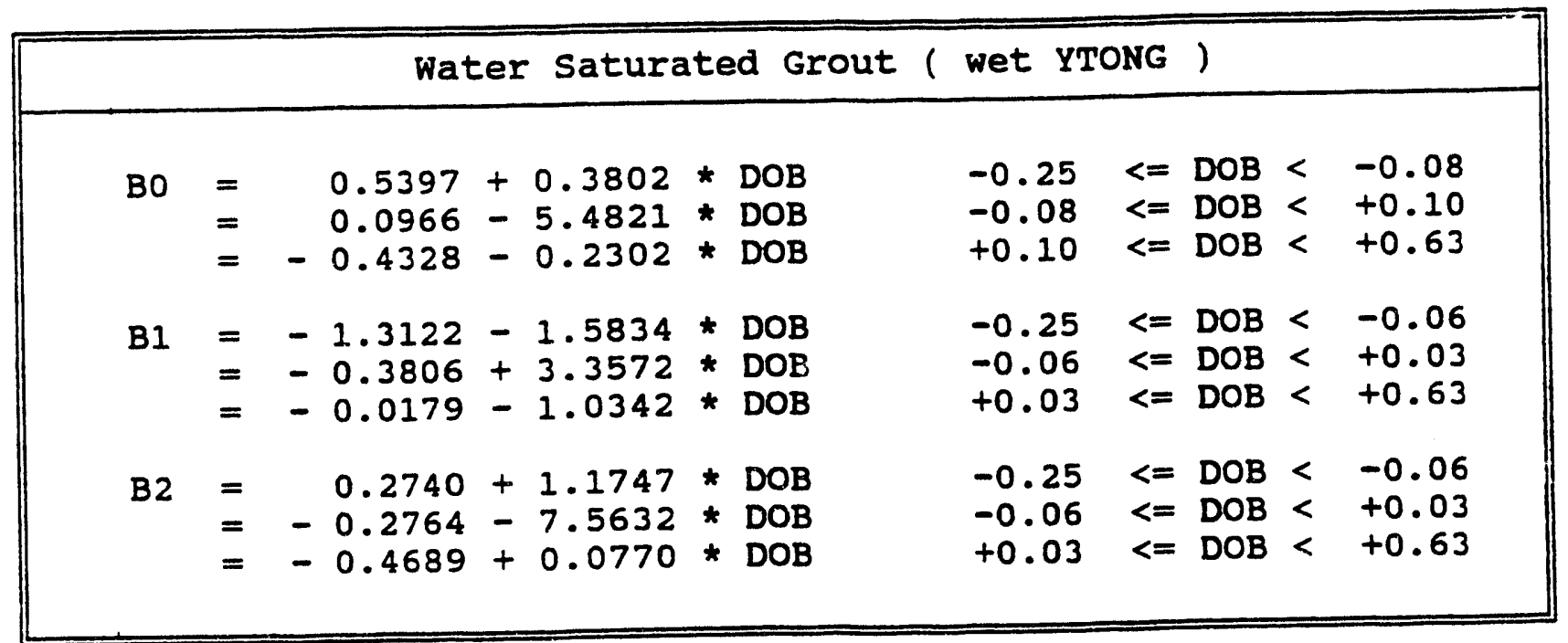

\begin{tabular}{|c|c|c|c|c|c|c|c|c|c|}
\hline \multicolumn{10}{|c|}{ Clay/Loam } \\
\hline BO & $\begin{array}{l}= \\
= \\
=\end{array}$ & $\begin{array}{r}0.5333 \\
-0.0446 \\
-0.3535\end{array}$ & $\begin{array}{l}+0.3548 \\
-8.8204 \\
-0.6492\end{array}$ & $\begin{array}{l}\text { * DOB } \\
\text { * DOB } \\
\text { * DOB }\end{array}$ & $\begin{array}{l}-0.25 \\
-0.06 \\
+0.04\end{array}$ & $\begin{array}{l}<= \\
<= \\
<=\end{array}$ & $\begin{array}{l}\text { DOB } \\
\text { DOB } \\
D O B\end{array}$ & $\begin{array}{l}< \\
< \\
<\end{array}$ & $\begin{array}{l}-0.06 \\
+0.04 \\
+0.63\end{array}$ \\
\hline B1 & $\begin{array}{l}= \\
= \\
=\end{array}$ & $\begin{array}{r}-1.1777 \\
0.0440 \\
0.0440\end{array}$ & $\begin{array}{l}-1.0580 \\
+8.3345 \\
-0.5294\end{array}$ & $\begin{array}{l}\text { * DOB } \\
\text { * DOB } \\
\text { * DOB }\end{array}$ & $\begin{array}{r}-0.25 \\
-0.06 \\
0.00\end{array}$ & $\begin{array}{l}<= \\
<= \\
<=\end{array}$ & $\begin{array}{l}\text { DOB } \\
\text { DOB } \\
\text { DOB }\end{array}$ & $\begin{array}{l}< \\
< \\
<\end{array}$ & $\begin{array}{r}-0.06 \\
0.00 \\
+0.63\end{array}$ \\
\hline B2 & $\begin{array}{l}= \\
= \\
=\end{array}$ & $\begin{array}{r}0.1773 \\
-0.6000 \\
-0.6000\end{array}$ & $\begin{array}{r}+0.7040 \\
-1.6356 \\
+0.1468\end{array}$ & $\begin{array}{l}\text { * DOB } \\
\text { * DOB } \\
\text { * DOB }\end{array}$ & $\begin{array}{r}-0.25 \\
-0.06 \\
0.00\end{array}$ & $\begin{array}{l}<= \\
<= \\
<=\end{array}$ & $\begin{array}{l}\text { DOB } \\
\text { DOB } \\
\text { DOB }\end{array}$ & $\begin{array}{l}< \\
< \\
<\end{array}$ & $\begin{array}{r}-0.06 \\
0.00 \\
+0.63\end{array}$ \\
\hline
\end{tabular}

Table 3. Coefficients of approximation functions for positive impulse vs ground range. DOB dependency described by polygon curves. $[D O B]=\mathrm{m} / \mathrm{kg}^{1 / 3}$ 


\subsubsection{Iso-Impulse DOB Curves}

In Figures 25 to 27, iso-impulse curves are given for the different soil materials. For comparison reasons, three sets of diagrams are shown, that is (a) spline function approximation, (b) polygon approximation and (c) polynomial approximation.

\subsection{ARRIVAL TIMES}

\subsubsection{Fit Functions}

For each set of arrival-timie data, fit functions of the form

(Eq. 10)

$$
\begin{gathered}
t_{a}=c_{1} \cdot \log G R+c_{2} / G R+G R / c_{0}+c_{3} \\
1 \leq G R\left[\mathrm{~m} / \mathrm{kg}^{1 / 3}\right] \leq 10
\end{gathered}
$$

have been determined, where $c_{0}$ means sound speed in air and $t_{a}$ and $G R$ are given in cube-root scaled values.

The values of the coefficients $c_{i}(i=1,2,3)$ are shown in Figures 28 to 30 . Besides the directly evaluated data from the experiments (dots), also the functions of the polygon (solid lines) and of the polynomial (dotted lines) approximations are plotted. The analytical description of the polygon curves can be found in Table 4. The range of validity applies to the interval:

(Eq. 11)

$$
\begin{aligned}
-0.25 & \leq \mathrm{DOB}\left[\mathrm{m} / \mathrm{kg}^{1 / 3}\right] \leq 0.63 \\
-2.0 & \leq \mathrm{DOB}[\mathrm{cm}] \leq 5.0
\end{aligned}
$$

The corresponding data for the polynomial presentation can be found in report $E 1 / 93$, pages 23 and 24.

\subsubsection{Arrival-Time Range Curves}

The function defined in Eq. 10 and Table 4 are used to calculate arrival-time vs ground-range curves. The results for polygon and polynomial approximations are presented in Figures 31 to 33. 


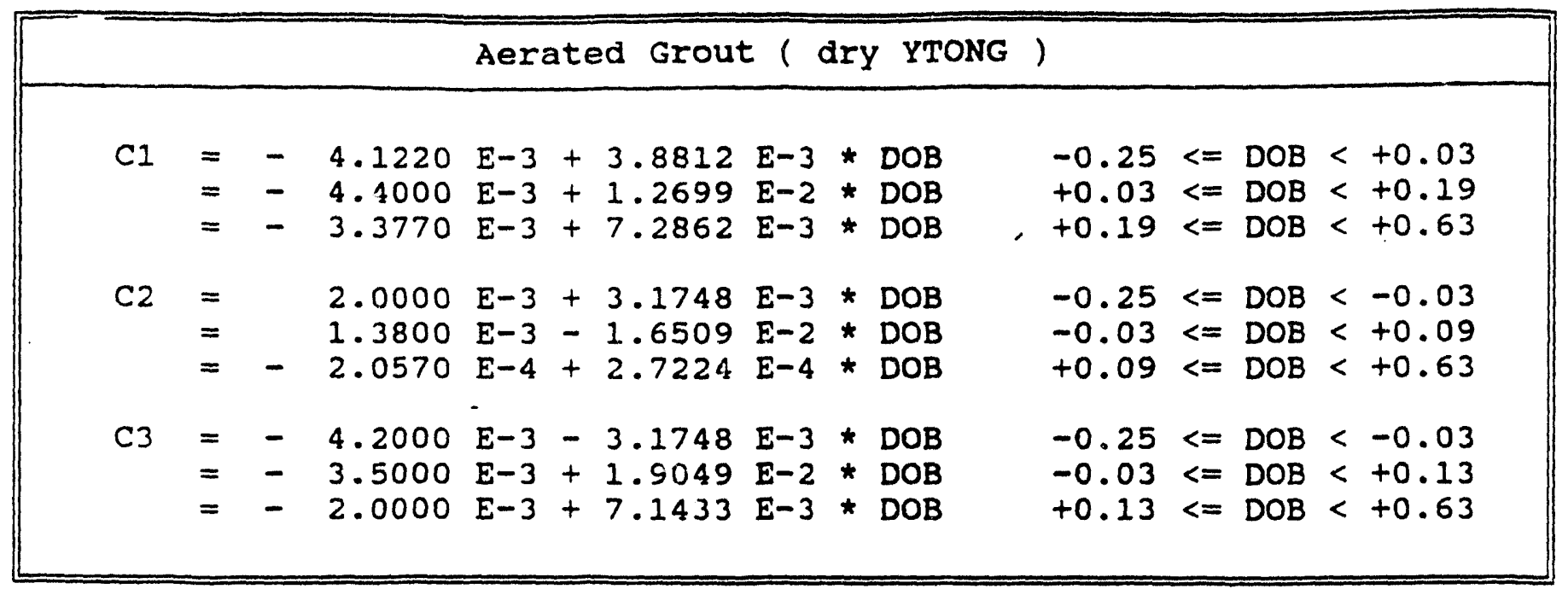

\begin{tabular}{|c|c|c|c|c|c|c|c|c|c|c|c|}
\hline & & & Wate & er $\mathrm{s}$ & Saturated & Grout & $t$ ( wet & YTONG ) & & & \\
\hline $\mathrm{Cl}$ & $\begin{array}{l}= \\
= \\
=\end{array}$ & $\begin{array}{l}- \\
-\end{array}$ & $\begin{array}{l}4.5572 \\
4.1457 \\
2.6436\end{array}$ & $\begin{array}{l}E-3 \\
E-3 \\
E-3\end{array}$ & $\begin{array}{r}+1.3604 \\
+1.4422 \\
+6.4734\end{array}$ & $\begin{array}{l}E-3 \\
E-2 \\
E-3\end{array}$ & $\begin{array}{l}\text { * DOB } \\
\text { * DOB } \\
\text { * DOB }\end{array}$ & $\begin{array}{l}-0.25 \\
-0.03 \\
+0.19\end{array}$ & $\begin{array}{l}<= \\
<= \\
<=\end{array}$ & $\begin{array}{l}\text { DOB }< \\
\text { DOB }< \\
D O B<\end{array}$ & $\begin{array}{l}-0.03 \\
<+0.19 \\
+0.63\end{array}$ \\
\hline $\mathrm{C} 2$ & $\begin{array}{l}= \\
= \\
=\end{array}$ & - & $\begin{array}{l}1.9546 \\
9.8350 \\
3.0270\end{array}$ & $\begin{array}{l}E-3 \\
E-4 \\
E-4\end{array}$ & $\begin{array}{r}+2.5978 \\
-1.9423 \\
+9.9609\end{array}$ & $\begin{array}{l}E-3 \\
E-2 \\
E-4\end{array}$ & $\begin{array}{l}\text { * DOB } \\
\text { * DOB } \\
\text { * DOB }\end{array}$ & $\begin{array}{l}-0.25 \\
-0.04 \\
+0.06\end{array}$ & $\begin{array}{l}<= \\
<= \\
<=\end{array}$ & $\begin{array}{l}\text { DOB }< \\
\text { DOB }< \\
D O B<\end{array}$ & $\begin{array}{l}-0.04 \\
+0.06 \\
+0.63\end{array}$ \\
\hline $\mathrm{C3}$ & $\begin{array}{l}= \\
= \\
=\end{array}$ & $\begin{array}{l}- \\
-\end{array}$ & $\begin{array}{l}4.2561 \\
3.0741 \\
1.8000\end{array}$ & $\begin{array}{l}E-3 \\
E-3 \\
E-4\end{array}$ & $\begin{array}{r}-2.4049 \\
+2.4399 \\
+\quad 1.4287\end{array}$ & $\begin{array}{l}E-3 \\
E-2 \\
E-3\end{array}$ & $\begin{array}{l}\text { * DOB } \\
\text { * DOB } \\
\text { * DOB }\end{array}$ & $\begin{array}{l}-0.25 \\
-0.04 \\
+0.13\end{array}$ & $\begin{array}{l}<= \\
<= \\
<=\end{array}$ & $\begin{array}{l}\text { DOB }< \\
\text { DOB }< \\
\text { DOB }<\end{array}$ & $\begin{array}{l}-0.04 \\
+0.13 \\
+0.63\end{array}$ \\
\hline
\end{tabular}

\begin{tabular}{|c|c|c|c|c|c|c|c|c|c|c|}
\hline \multicolumn{11}{|c|}{ Clay/Loam } \\
\hline Cl & $\begin{array}{l}= \\
= \\
=\end{array}$ & $\begin{array}{l}-\quad 4.5200 \\
-\quad 5.5834 \\
-\quad 7.7500\end{array}$ & $\begin{array}{l}E-3 \\
E-3 \\
E-4\end{array}$ & $\begin{array}{l}+3.4923 \\
+\quad 2.0372 \\
+\quad 1.2898\end{array}$ & $\begin{array}{l}E-3 \\
E-2 \\
E-3\end{array}$ & $\begin{array}{l}\text { * DOB } \\
\text { * DOB } \\
\text { * DOB }\end{array}$ & $\begin{array}{l}-0.25 \\
+0.06 \\
+0.25\end{array}$ & $\begin{array}{l}<= \\
<= \\
<=\end{array}$ & $\begin{array}{l}\text { DOB }< \\
D O B< \\
D O B<\end{array}$ & $\begin{array}{l}+0.06 \\
+0.25 \\
+0.63\end{array}$ \\
\hline $\mathrm{C} 2$ & $\begin{array}{l}= \\
= \\
=\end{array}$ & $\begin{array}{r}1.7767 \\
5.5000 \\
-\quad 5.6180\end{array}$ & $\begin{array}{l}E-3 \\
E-4 \\
E-4\end{array}$ & $\begin{array}{l}+2.8041 \\
-1.6668 \\
+9.8101\end{array}$ & $\begin{array}{l}E-3 \\
E-2 \\
E-4\end{array}$ & $\begin{array}{l}\text { * DOB } \\
\text { * DOB } \\
\text { * DOB }\end{array}$ & $\begin{array}{l}-0.25 \\
-0.06 \\
+0.06\end{array}$ & $\begin{array}{l}<= \\
<= \\
<=\end{array}$ & $\begin{array}{l}\text { DOB }< \\
\text { DOB }< \\
\text { DOB }<\end{array}$ & $\begin{array}{l}-0.06 \\
<+0.06 \\
+0.63\end{array}$ \\
\hline C3 & $\begin{array}{l}= \\
= \\
=\end{array}$ & $\begin{array}{l}-\quad 4.2000 \\
-\quad 2.8000 \\
-\quad 3.4000\end{array}$ & $\begin{array}{l}E-3 \\
E-3 \\
E-4\end{array}$ & $\begin{array}{r}-3.1748 \\
+\quad 1.9049 \\
-\quad 4.7622\end{array}$ & $\begin{array}{l}E-3 \\
E-2 \\
E-4\end{array}$ & $\begin{array}{l}\text { * DOB } \\
\text { * DOB } \\
\text { * DOB }\end{array}$ & $\begin{array}{l}-0.25 \\
-0.06 \\
+0.13\end{array}$ & $\begin{array}{l}<= \\
<= \\
<=\end{array}$ & $\begin{array}{l}\text { DOB }< \\
\text { DOB }< \\
D O B<\end{array}$ & $\begin{array}{l}-0.06 \\
<+0.13 \\
<+0.63\end{array}$ \\
\hline
\end{tabular}

Table 4. Coefficients of approximation functions for arrival time vs ground range. DOB dependency described by polygon curves.

$[D O B]=\mathrm{m} / \mathrm{kg}^{1 / 3}$ 
As could already be assumed from the deviations of the approximation values of the coefficients for the soil material clay/loam (Figure 30), considerable differences occur for this kind of soil in the arrival-time range curves (Figure 33). The polygonal approximation, however, corresponds more closely to reality.

\subsubsection{Constant Arrival Time DOB Curves}

In Figures 34 to 36, the iso-arrival time DOB curves are given for the different soil materials. For comparison reasons, three sets of diagrams are shown, i.e., (a) spline function approximation, (b) polygon approximation, (c) polynomial approximation, respectively.

\subsection{POSITIVE PHASE DURATIONS}

\subsubsection{Fit Functions}

For each set of positive phase duration data, fit functions of the form:

(Eq. 12)

$$
\begin{gathered}
\log t+=e_{0}+e_{1} \log G R+e_{2}(\log G R)^{2} \\
1 \leq G R\left[m / k^{1 / 3}\right] \geq 10
\end{gathered}
$$

have been determined. The values of the coefficients $e_{i}(i=0,1,2)$ are shown in Figures 37 to 39. Besides the directly evaluated data from the experiments (dots), also the functions of the polygonial (solid lines) and of the polynomial approximation (dotted lines) are plotted. The analytical description of the polygonal curves can be found in Table 5. The range of validity applies to the interval:

$$
\begin{aligned}
-0.25 & \leq \mathrm{DOB}\left[\mathrm{m} / \mathrm{kg}^{1 / 3}\right] \leq 0.63 \\
-2.0 & \leq \mathrm{DOB}[\mathrm{cm}] \leq 5.0
\end{aligned}
$$




\begin{tabular}{|c|c|c|c|c|c|c|c|c|c|}
\hline & & & Aerated & Grout ( dry & YTONG & ) & & & \\
\hline EO & $\begin{array}{l}= \\
= \\
=\end{array}$ & $\begin{array}{l}-2.8800 \\
-2.8800 \\
-3.1639\end{array}$ & $\begin{array}{l}+1.1112 \\
-7.3020 \\
+1.7120\end{array}$ & $\begin{array}{l}\star D O B \\
\star D O B \\
\star D O B\end{array}$ & $\begin{array}{r}-0.25 \\
0.00 \\
+0.03\end{array}$ & $\begin{array}{l}<= \\
<= \\
<=\end{array}$ & $\begin{array}{l}\text { DOB } \\
\text { DOB } \\
\text { DOB }\end{array}$ & $\begin{array}{l}< \\
< \\
<\end{array}$ & $\begin{array}{r}0.00 \\
+0.03 \\
+0.63\end{array}$ \\
\hline E1 & $\begin{array}{l}= \\
= \\
= \\
=\end{array}$ & $\begin{array}{r}0.6200 \\
0.6200 \\
1.4822 \\
-0.2257\end{array}$ & $\begin{array}{l}-2.0636 \\
+3.1761 \\
-4.1979 \\
+1.2247\end{array}$ & $\begin{array}{l}\text { * DOB } \\
\text { * DOB } \\
\text { * DOB } \\
\text { * DOB }\end{array}$ & $\begin{array}{r}-0.25 \\
0.00 \\
+0.03 \\
+0.31\end{array}$ & $\begin{array}{l}<= \\
<= \\
<= \\
<=\end{array}$ & $\begin{array}{l}\text { DOB } \\
\text { DOB } \\
\text { DOB } \\
\text { DOB }\end{array}$ & $\begin{array}{l}< \\
< \\
< \\
<\end{array}$ & $\begin{array}{r}0.00 \\
+0.03 \\
+0.31 \\
+0.63\end{array}$ \\
\hline E2 & $\begin{array}{l}= \\
= \\
= \\
=\end{array}$ & $\begin{array}{r}0.0000 \\
0.0000 \\
-\quad 0.6833 \\
0.5429\end{array}$ & $\begin{array}{l}+1.3493 \\
-9.6838 \\
+2.0104 \\
-1.8819\end{array}$ & $\begin{array}{l}\text { * DOB } \\
\text { * DOB } \\
\text { * DOB } \\
\text { * DOB }\end{array}$ & $\begin{array}{r}-0.25 \\
0.00 \\
+0.03 \\
+0.31\end{array}$ & $\begin{array}{l}<= \\
<= \\
<= \\
<=\end{array}$ & $\begin{array}{l}D O B \\
D O B \\
D O B \\
D O B\end{array}$ & $\begin{array}{l}< \\
< \\
< \\
<\end{array}$ & $\begin{array}{r}0.00 \\
+0.03 \\
+0.31 \\
+0.63\end{array}$ \\
\hline
\end{tabular}

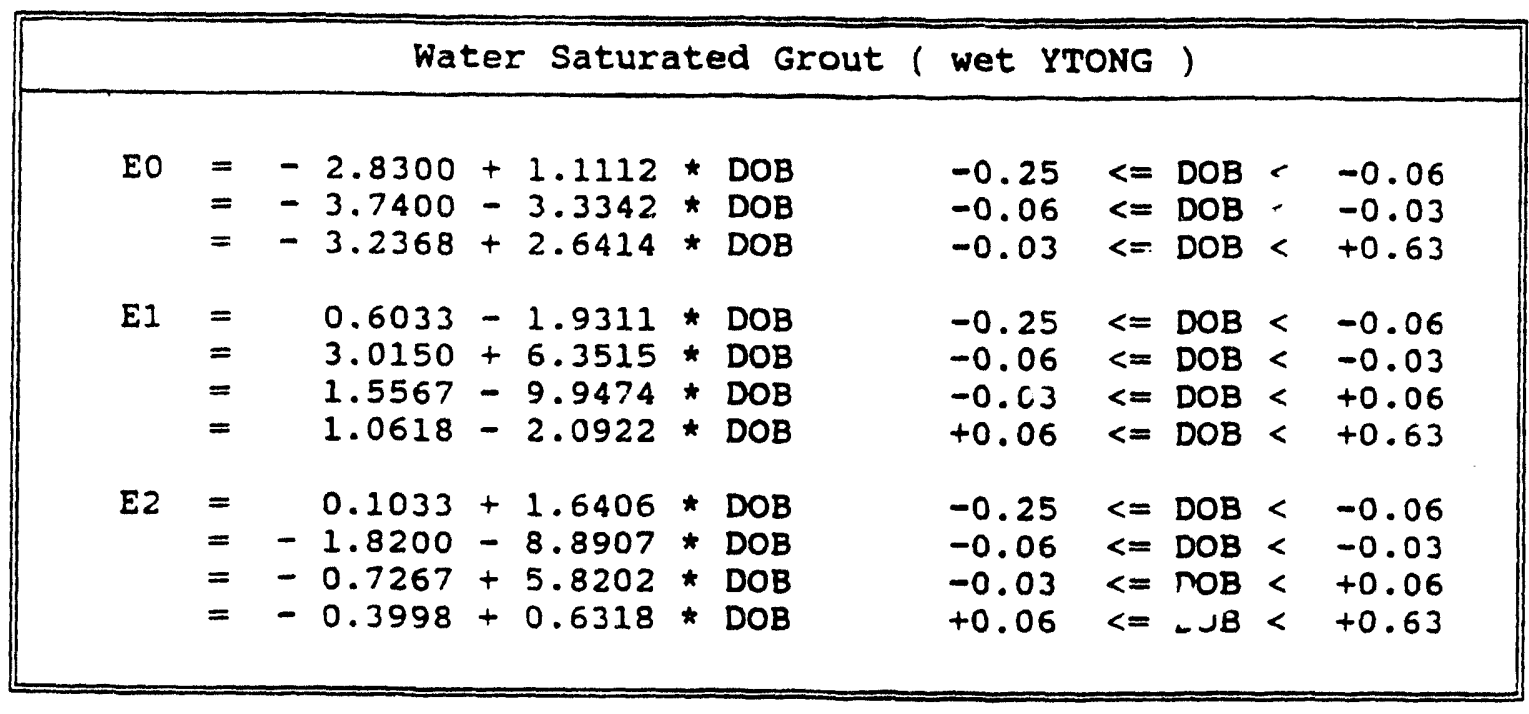

\begin{tabular}{|c|c|c|c|c|c|c|c|c|c|c|}
\hline \multicolumn{11}{|c|}{ Clay/Loam } \\
\hline EO & $\begin{array}{l}= \\
= \\
= \\
=\end{array}$ & $\begin{array}{l}-2.7633 \\
-3.2400 \\
-3.2400 \\
-2.4850\end{array}$ & $\begin{array}{l}+1.3755 \\
-6.1909 \\
+3.6113 \\
+0.6151\end{array}$ & $\begin{array}{l}* \\
\star \\
\star \\
*\end{array}$ & $\begin{array}{l}\text { DOB } \\
\text { DOB } \\
\text { DOB } \\
\text { DOB }\end{array}$ & $\begin{array}{r}-0.25 \\
-0.06 \\
0.00 \\
+0.25\end{array}$ & $\begin{array}{l}<= \\
<= \\
<= \\
<=\end{array}$ & $\begin{array}{l}\text { DOB } \\
\text { DOB } \\
\text { DOB } \\
\text { DOB }\end{array}$ & $\begin{array}{l}< \\
< \\
< \\
<\end{array}$ & $\begin{array}{r}-0.06 \\
0.00 \\
+0.25 \\
+0.63\end{array}$ \\
\hline E1 & $\begin{array}{l}= \\
= \\
= \\
=\end{array}$ & $\begin{array}{r}0.2633 \\
1.3200 \\
1.3200 \\
-0.3245\end{array}$ & $\begin{array}{l}-3.2804 \\
+\quad 3.4929 \\
-4.4169 \\
+\quad 2.1097\end{array}$ & $\begin{array}{l}\star \\
\star \\
\star \\
\star\end{array}$ & $\begin{array}{l}\text { DOB } \\
\text { DOB } \\
\text { DOB } \\
\text { DOB }\end{array}$ & $\begin{array}{r}-0.25 \\
-0.06 \\
0.00 \\
+0.25\end{array}$ & $\begin{array}{l}<= \\
<= \\
<= \\
<=\end{array}$ & $\begin{array}{l}\text { DOB } \\
\text { DOB } \\
\text { DOB } \\
\text { DOB }\end{array}$ & $\begin{array}{l}< \\
< \\
< \\
<\end{array}$ & $\begin{array}{r}-0.06 \\
0.00 \\
+0.25 \\
+0.63\end{array}$ \\
\hline E2 & $\begin{array}{l}= \\
= \\
= \\
=\end{array}$ & $\begin{array}{r}0.0933 \\
-\quad 0.4660 \\
-\quad 0.4171 \\
-0.1160\end{array}$ & $\begin{array}{l}+1.4818 \\
-7.3973 \\
+0.8334 \\
-0.3611\end{array}$ & $\begin{array}{l}* \\
\star \\
\star \\
*\end{array}$ & $\begin{array}{l}D O B \\
D O B \\
D O B \\
D O B\end{array}$ & $\begin{array}{r}-0.25 \\
-0.06 \\
0.00 \\
+0.25\end{array}$ & $\begin{array}{l}<= \\
<= \\
<= \\
<=\end{array}$ & $\begin{array}{l}\text { DOB } \\
\text { DOB } \\
\text { DOB } \\
\text { DOB }\end{array}$ & $\begin{array}{l}< \\
< \\
< \\
<\end{array}$ & $\begin{array}{r}-0.06 \\
0.00 \\
+0.25 \\
+0.63\end{array}$ \\
\hline
\end{tabular}

Table 5 . Coefficients of approximation functions for positive pecik duration is grolund range. DOB dependency described by polygon curves.
$[D O B]=\mathrm{m} / \mathrm{kg}^{1 / 3}$ 
The corresponding data for the polynomial presentation can be found in report E 1/93, pages 25 and 26.

\subsubsection{Duration Range Curves}

The functions defined in Eq. 12 and Table 5 are used to calculate positive-phase duration vs ground-range curves. The results for polygon and polynomial approximations are presented in Figures 40 to 42 . The deviations remain in the ordinary course. It should be pointed out that it is difficult to measure the positive phase duration and also that open points exist as to what is the correct value in porched shock fronts or compressions waves situations.

\subsubsection{Constant Duration DOB Curves}

In Figures 43 to 45 , the DOB curves for constant positive phase duration are given. As for the other blastwave parameters, three sets of diagrams are shown, i.e., (a) spline functions approximation, (b) polygon approximation, (c) polynomial approximation, respectively. 


\section{SECTION 3}

\section{CONCLUSIONS}

The second-order approximation for the coefficients of the propagation functions of the different blastwave parameters did not lead to a satisfactory description of the processes in all cases. An improvement was achieved by means of polygon approximation, although the DOB curves sometimes showed kinks at the interval boundaries. However, the achievement was made that in the experimentally investigated interval

$$
-0.25 \leq \mathrm{DOB}\left[\mathrm{m} / \mathrm{kg}^{1 / 3}\right] \leq 0.63
$$

a very simple analytical description of the blastwave parameters for any depth of burst is now available.

At the same time, the approximations used also show distinctly that the DOB curves depend strongly on small deviations in the used sets of data.

On the whole, however, it can be stated that the range of deviations is still tolerable, since -in contrast to the usual $\mathrm{DOB} / \mathrm{HOB}$ curves -- the results were presented in a very distorted scale. Apart from that, an experimentally verified transition from HOB to DOB for different blastwave parameters has been made available by the help of the consistent data material described here. 


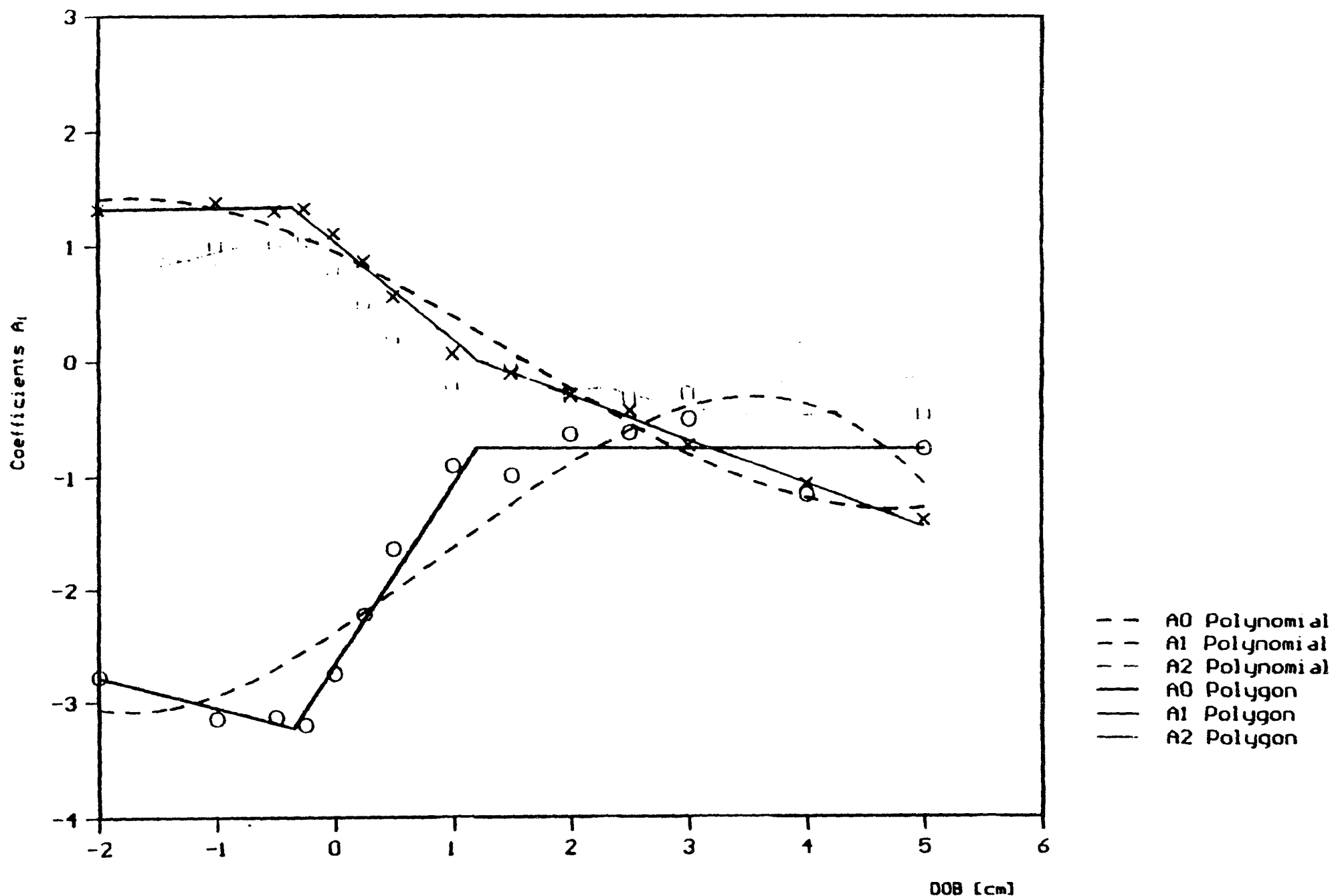

Figure 1. Coefficients of approximation functions for peak overpressure vs ground range at different DOB.

Aeraced grout (dry YTONG)

polynomial and polygon approximation 


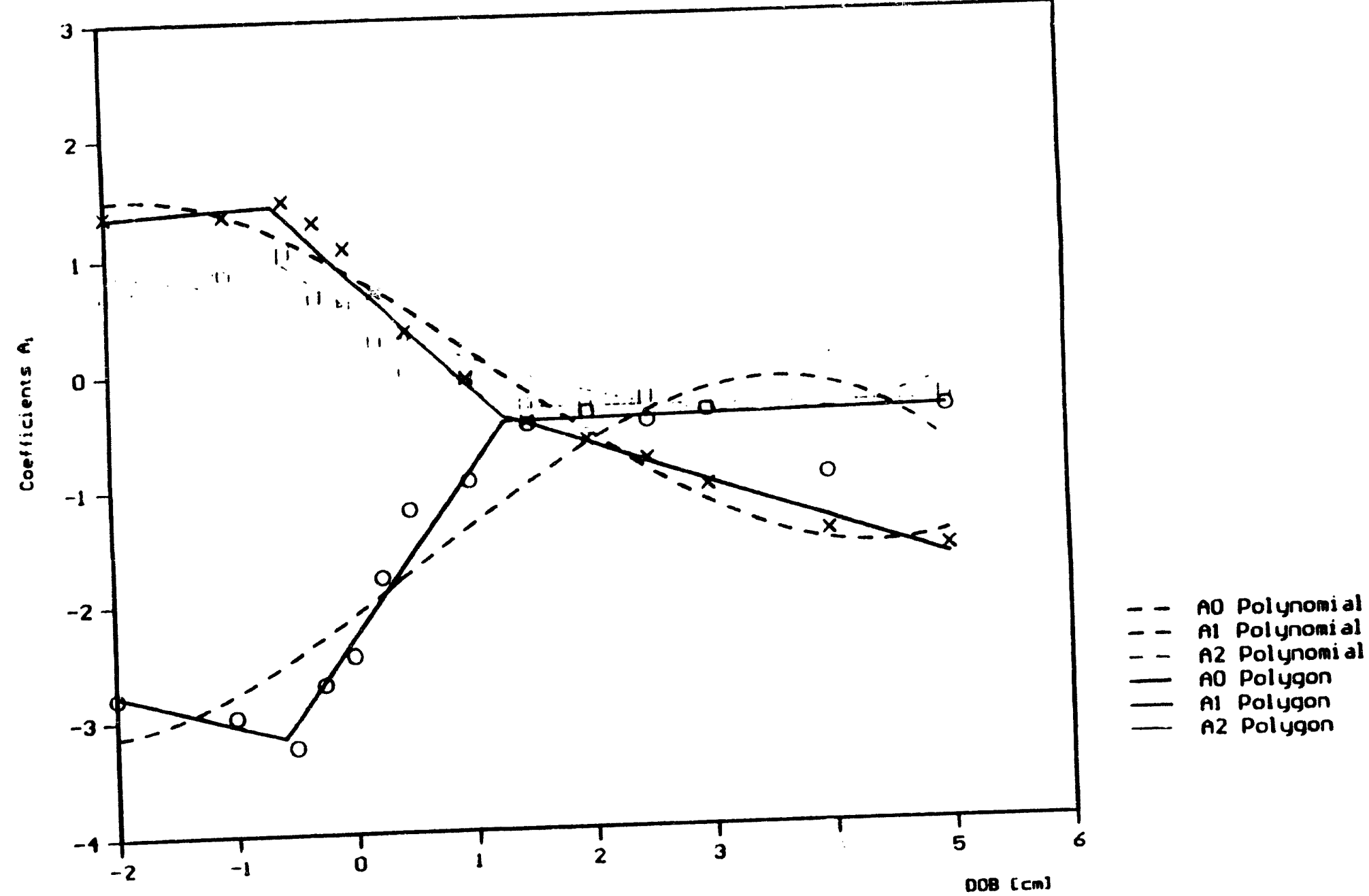

Figure 2. Coefficients of approximation functions for peak overpressure vs ground range at different $D O B$.

Water-saturated grout (wet YTONG)

polynomial and polygon approximation 


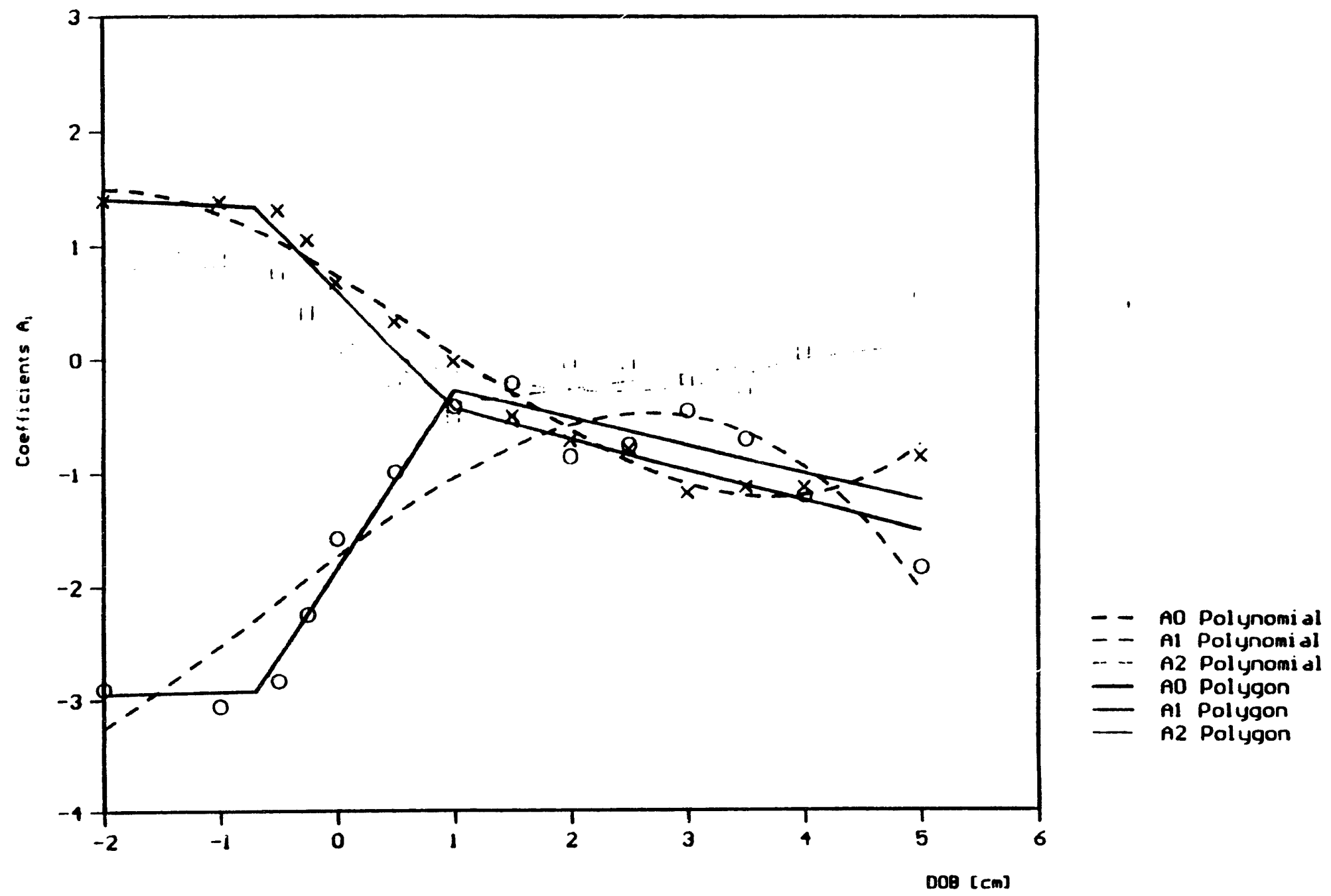

Figure 3. Coefficients of approximation functions for peak overpressure vs ground range at different $\mathrm{DOB}$.

Wet clay/loam

polynomial and polygon approximation 

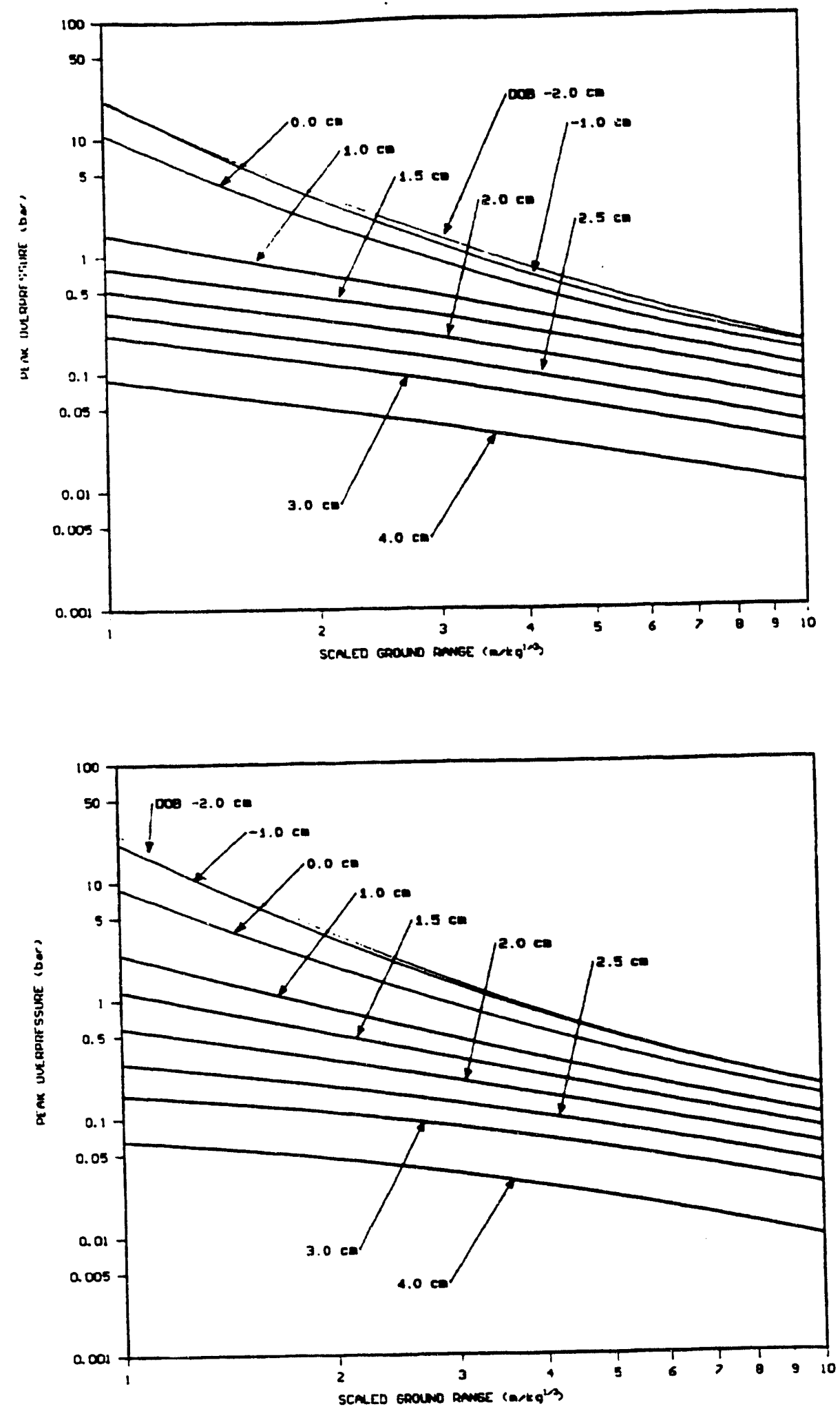

Figure 4. Peak overpressure vs ground range curves for different DOB Aerated grout (dry YTONG)
(a) polygon approximation
(b) polynomial approximation 

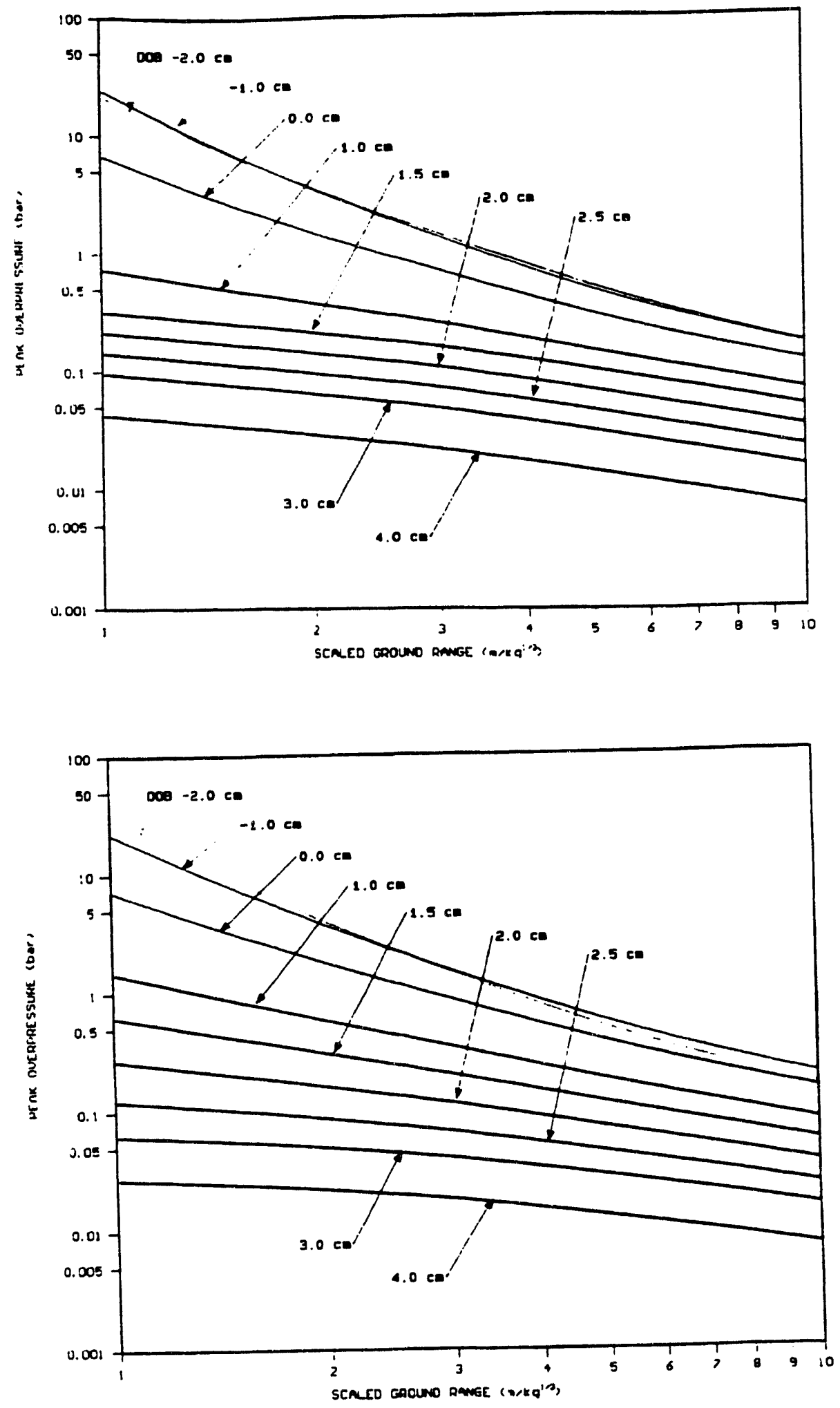

Figure 5. Peak overpressure vs ground range curves for different DOB Water-saturated groul (wet YTONG)
(a) polygon approximation
(b) polynomial approximation 

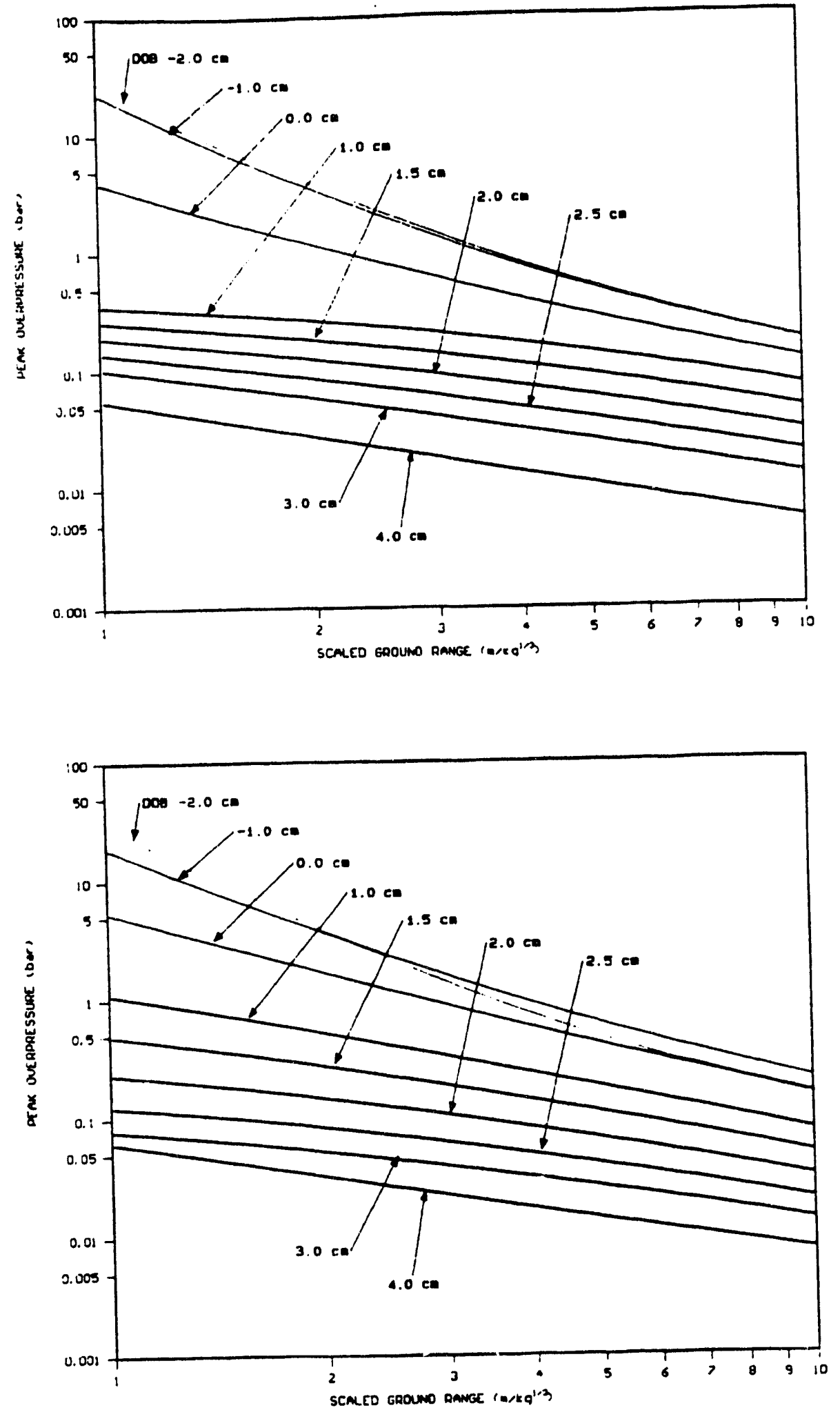

Figure 6. Peak overpressure vs ground range curves for different DOB Wet clay/loam
(a) polygon approximation
(b) polynomial approximation 


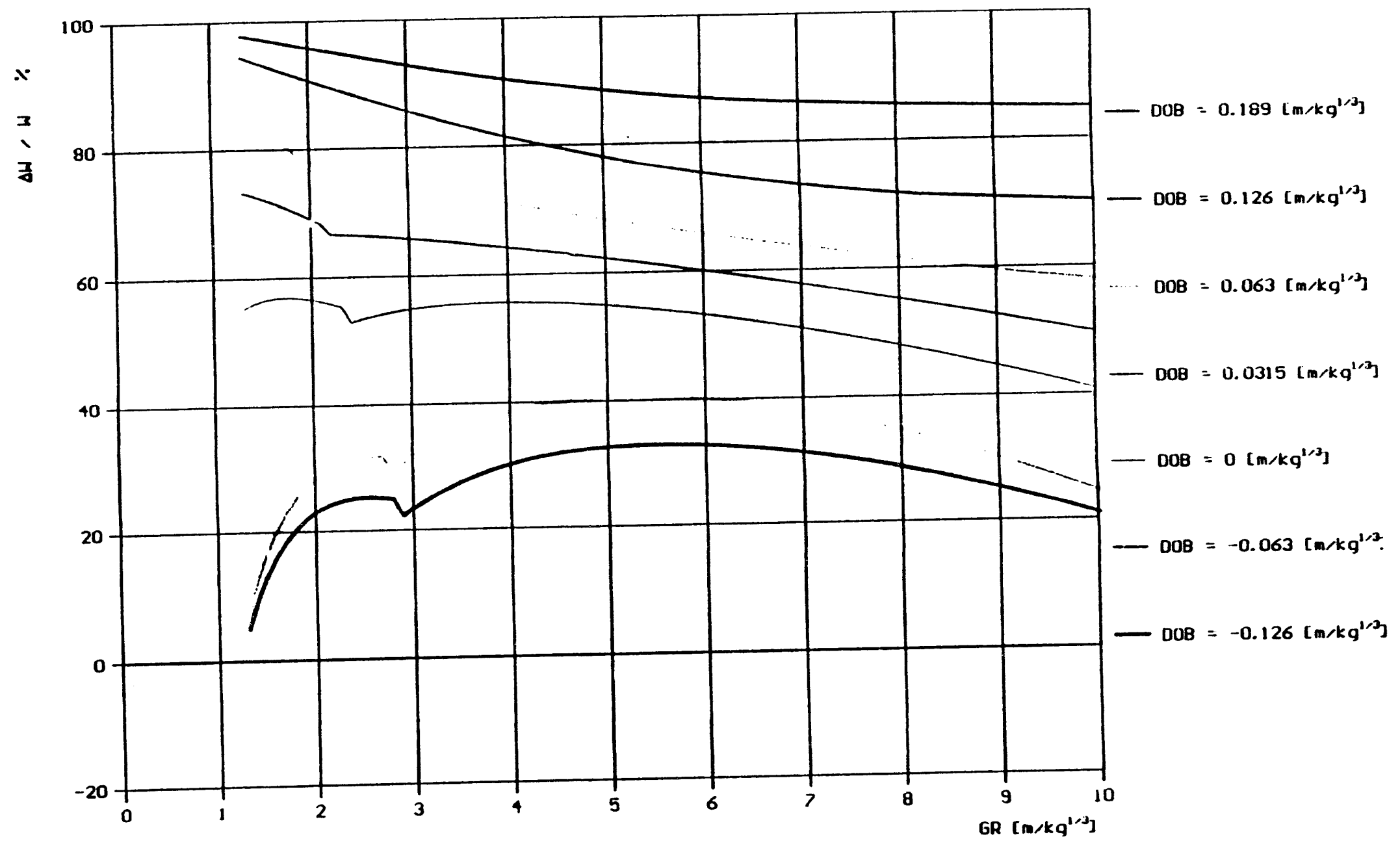

Figure 7a. Percentage of energy losses vs ground range Soil material: dry aerated grout (dry YTONG)

Polygon approximarion 


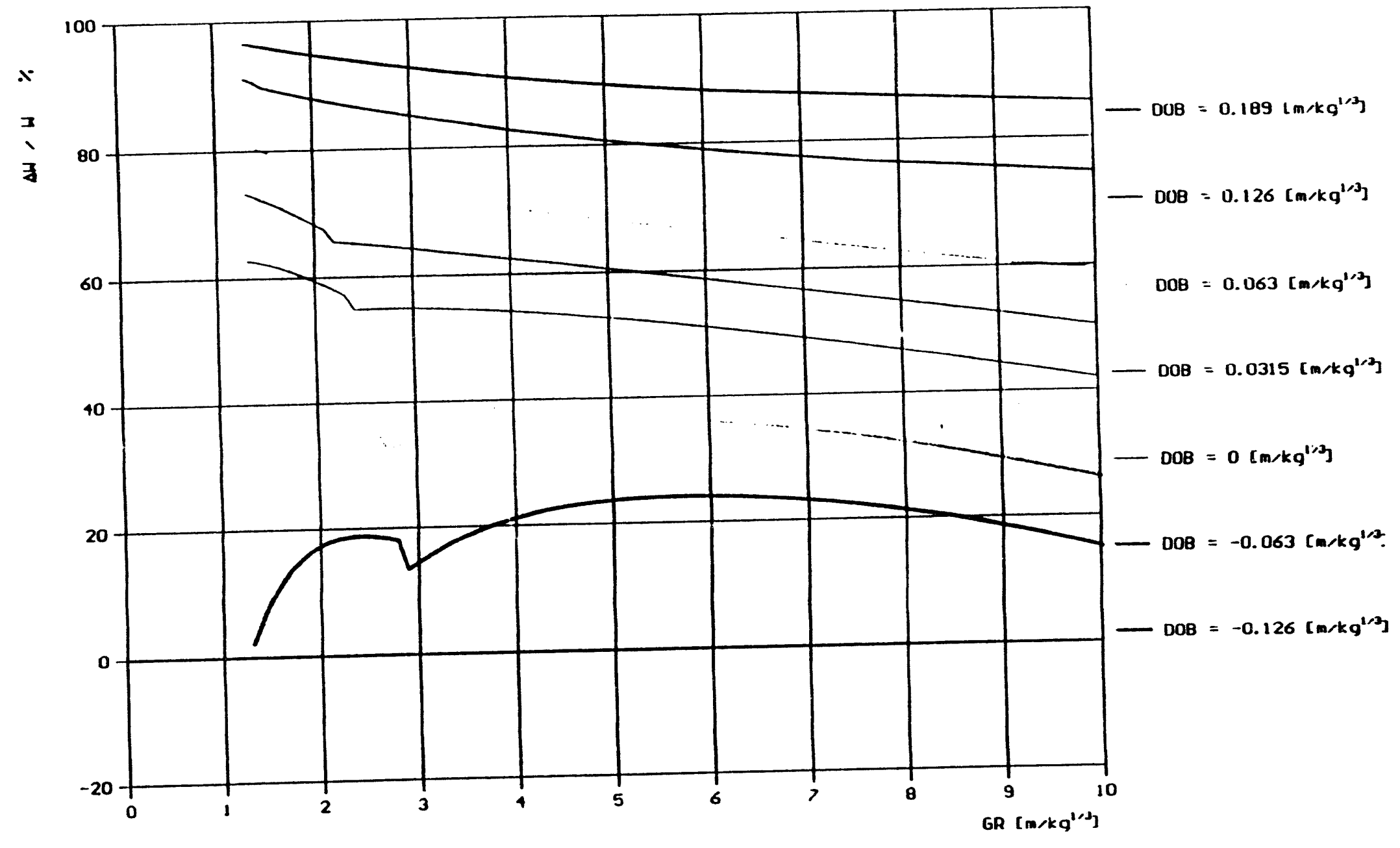

Figure 7b. Percentage of energy losses vs ground range

Soil material: dry aerated g
Polynomial approximation 


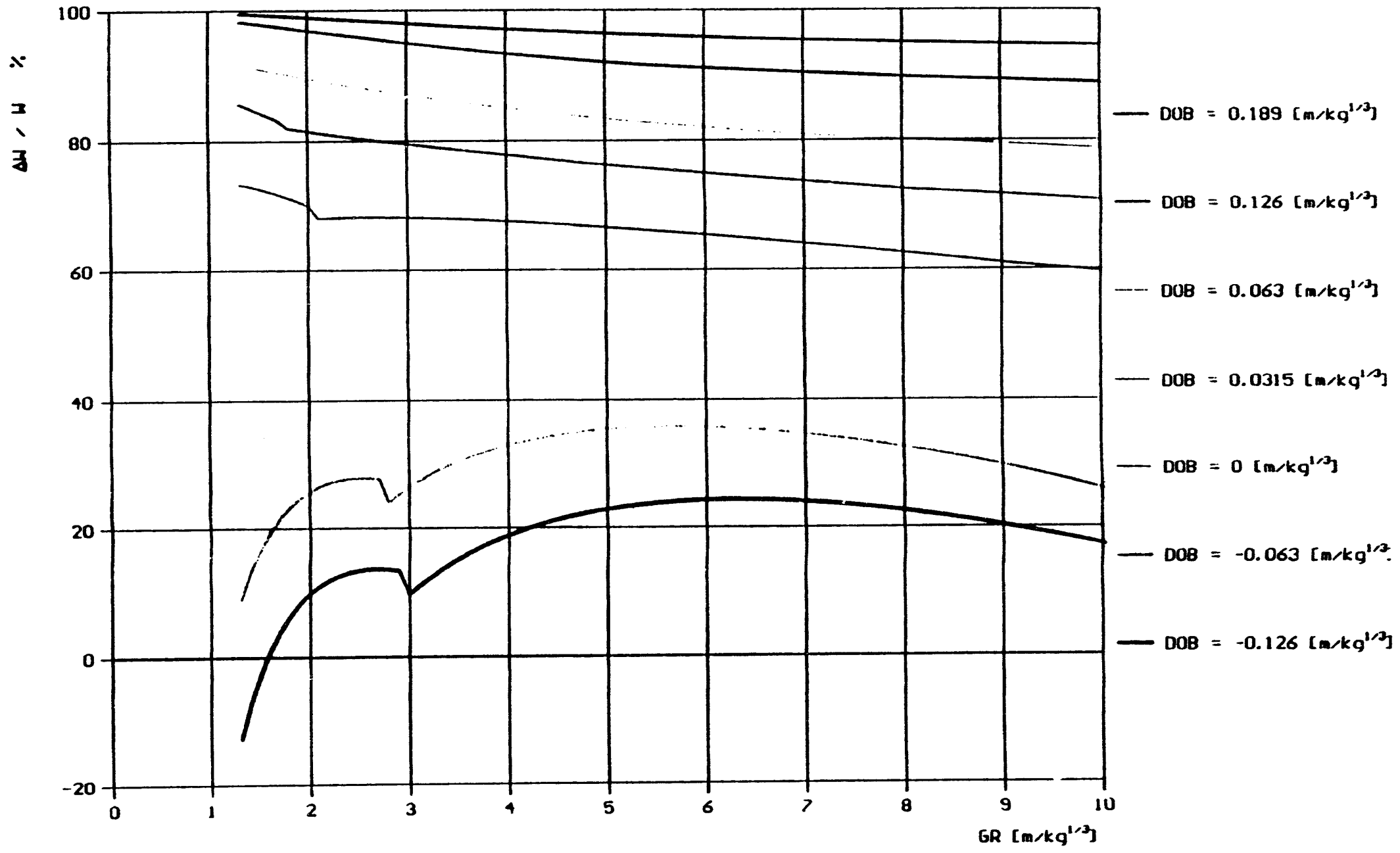

Figure 8a. Percentage of energy losses vs ground range Soil material: water-saturated grout (wet YTONG) Polygon approximation 


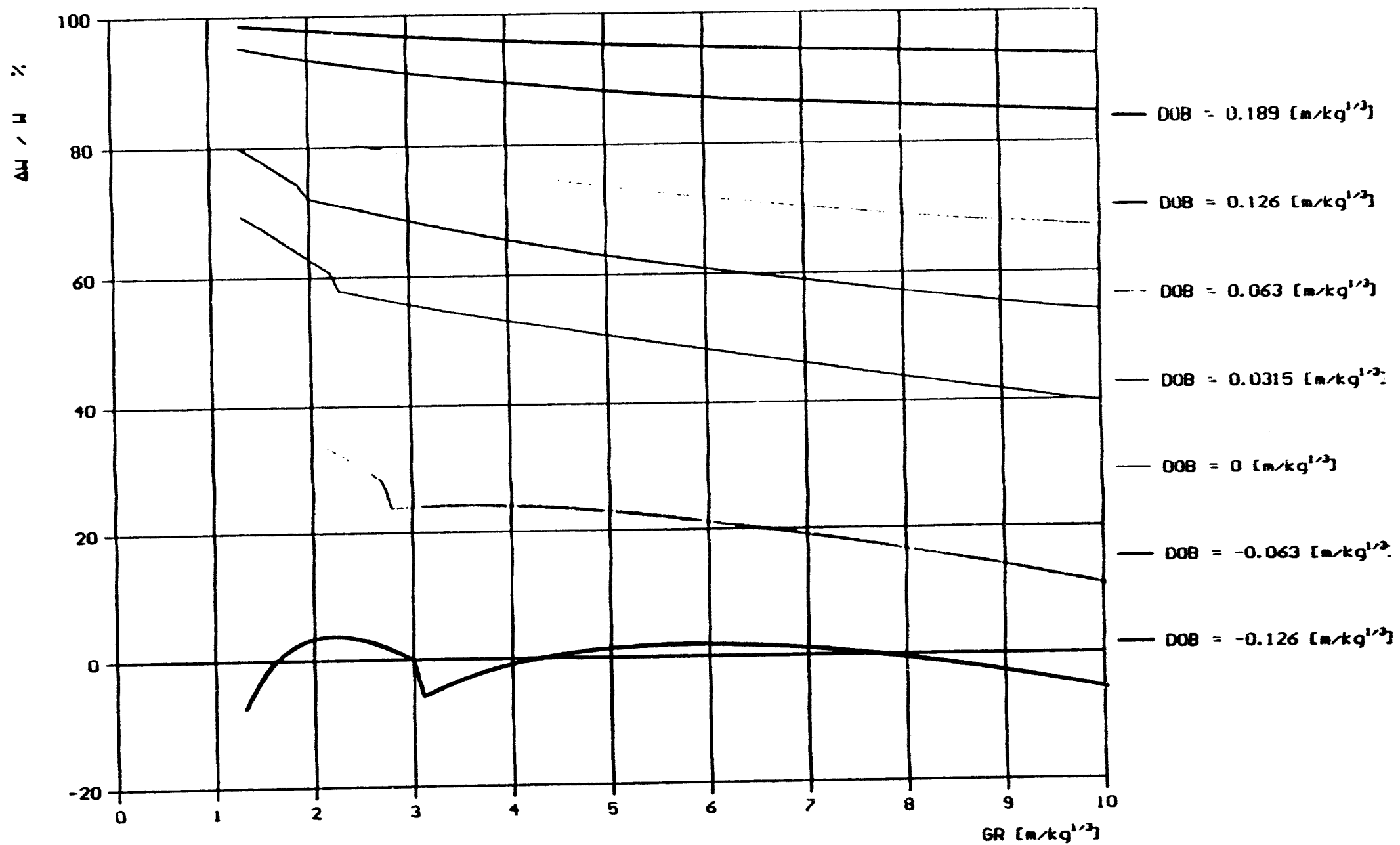

Figure 8b. Percentage of energy losses vs ground range Soil material: water-saturated grout (wet YTONG) Polynomial approximation 


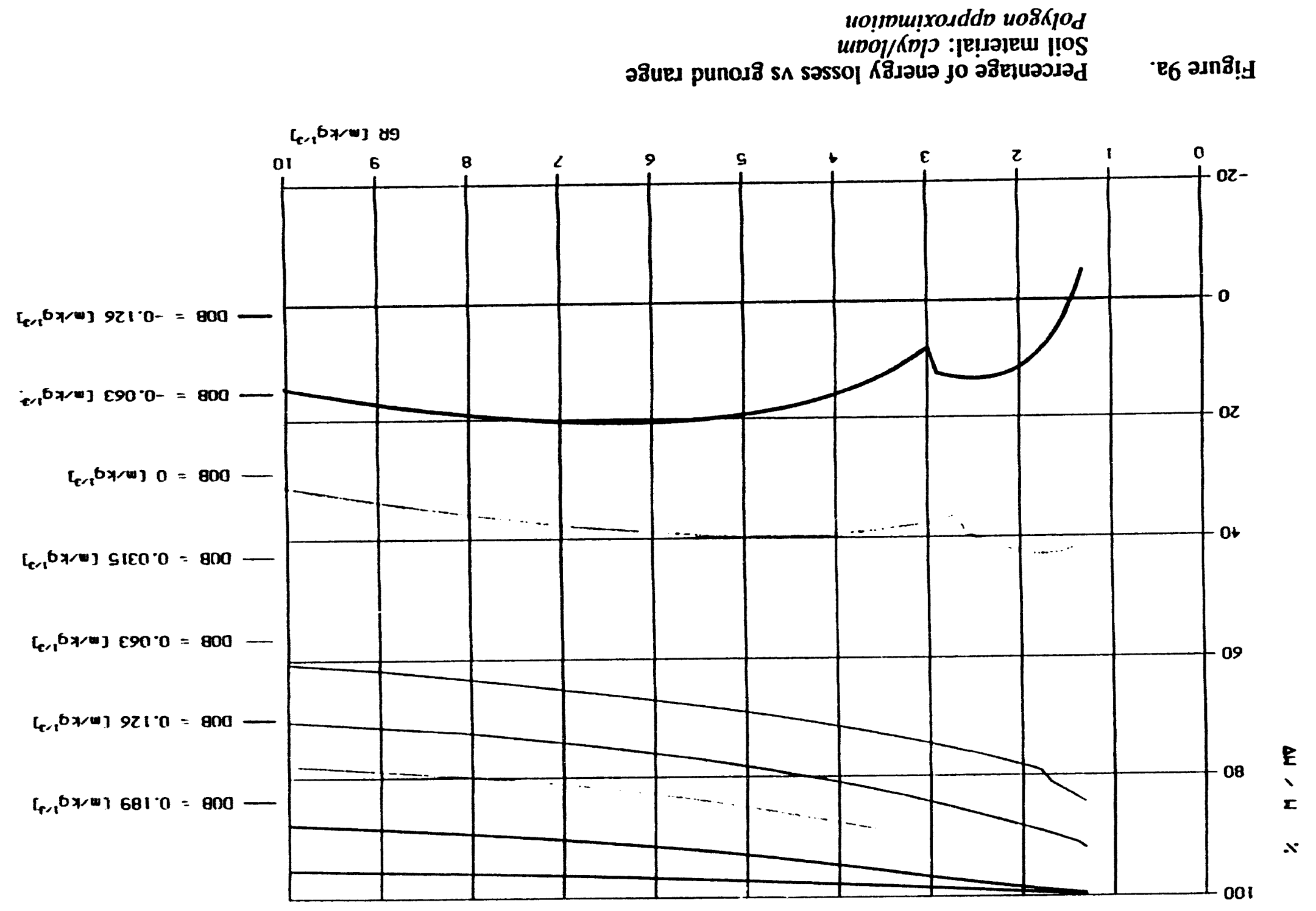




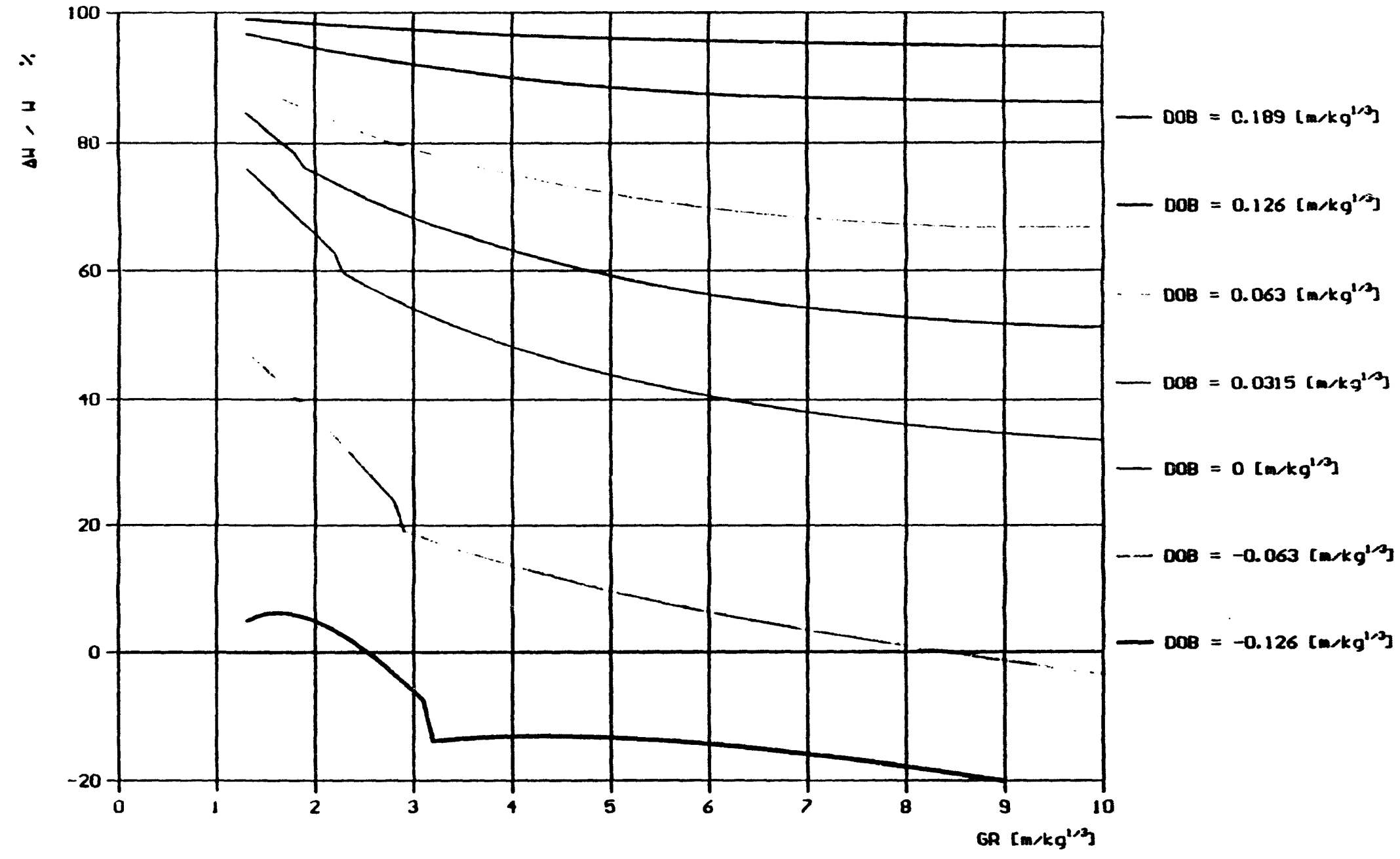

Figure 9b. Percentage of energy losses vs ground range Soil material: clay/loam

Polynomial approximation 


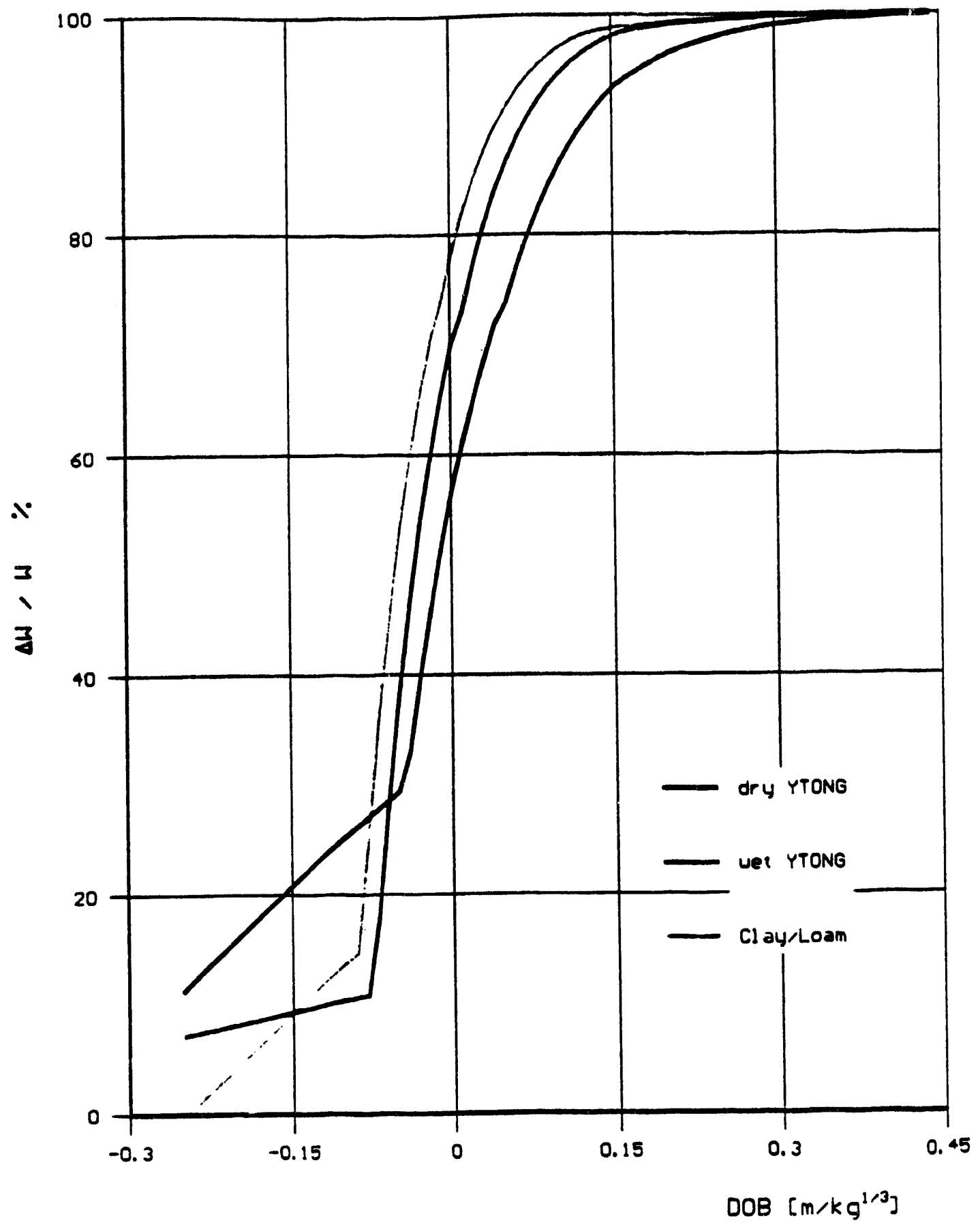

Figure 10a. Percentage of energy losses vs DOB at $G R=2\left[\mathrm{~m} / \mathrm{kg}^{1 / 3}\right]$ Polygon approximation 


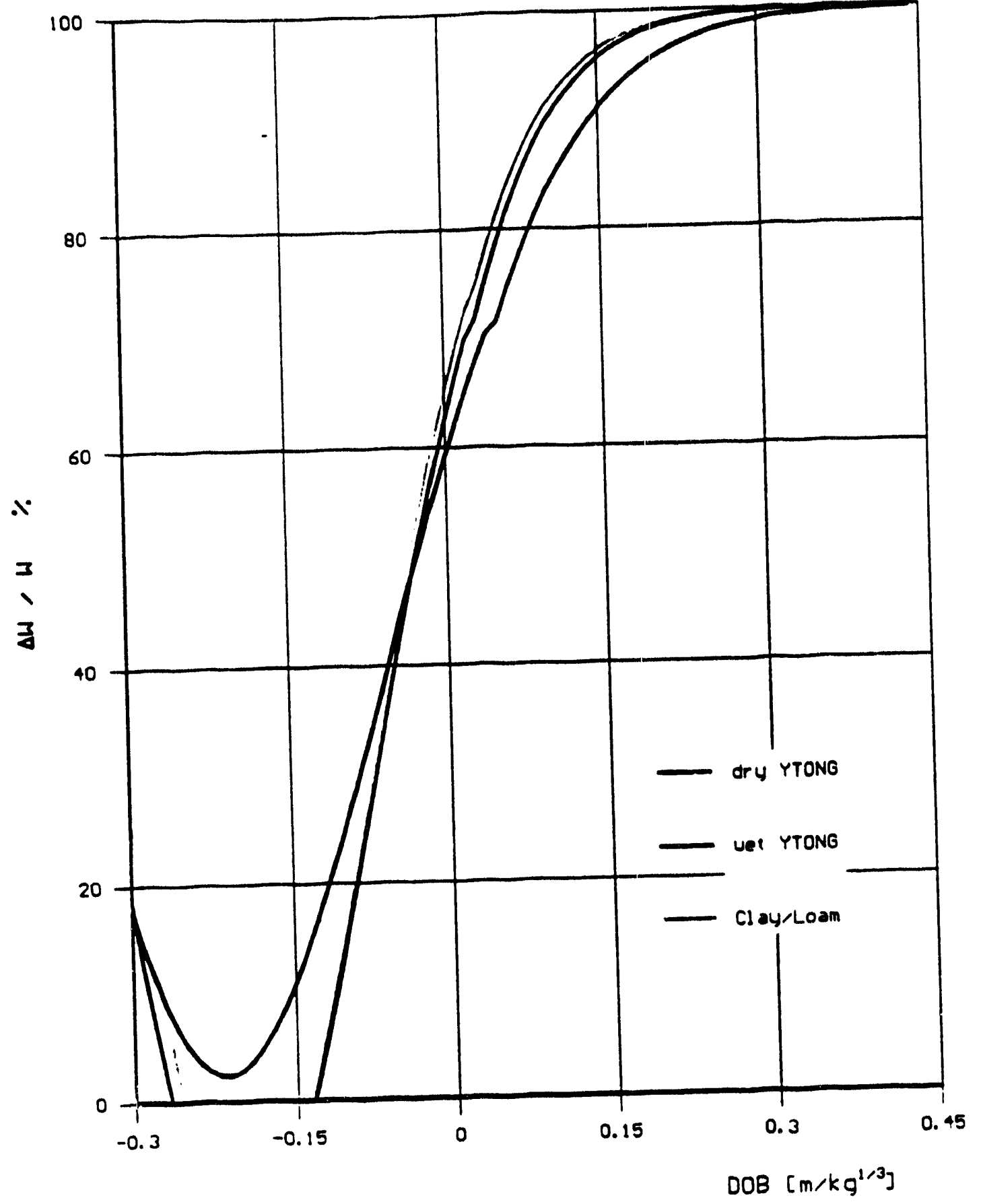

Figure 10b. Percentage of energy losses vs DOB at $G R=2\left[\mathrm{~m} / \mathrm{kg}^{1 / 3}\right]$ Polynomial approximation 


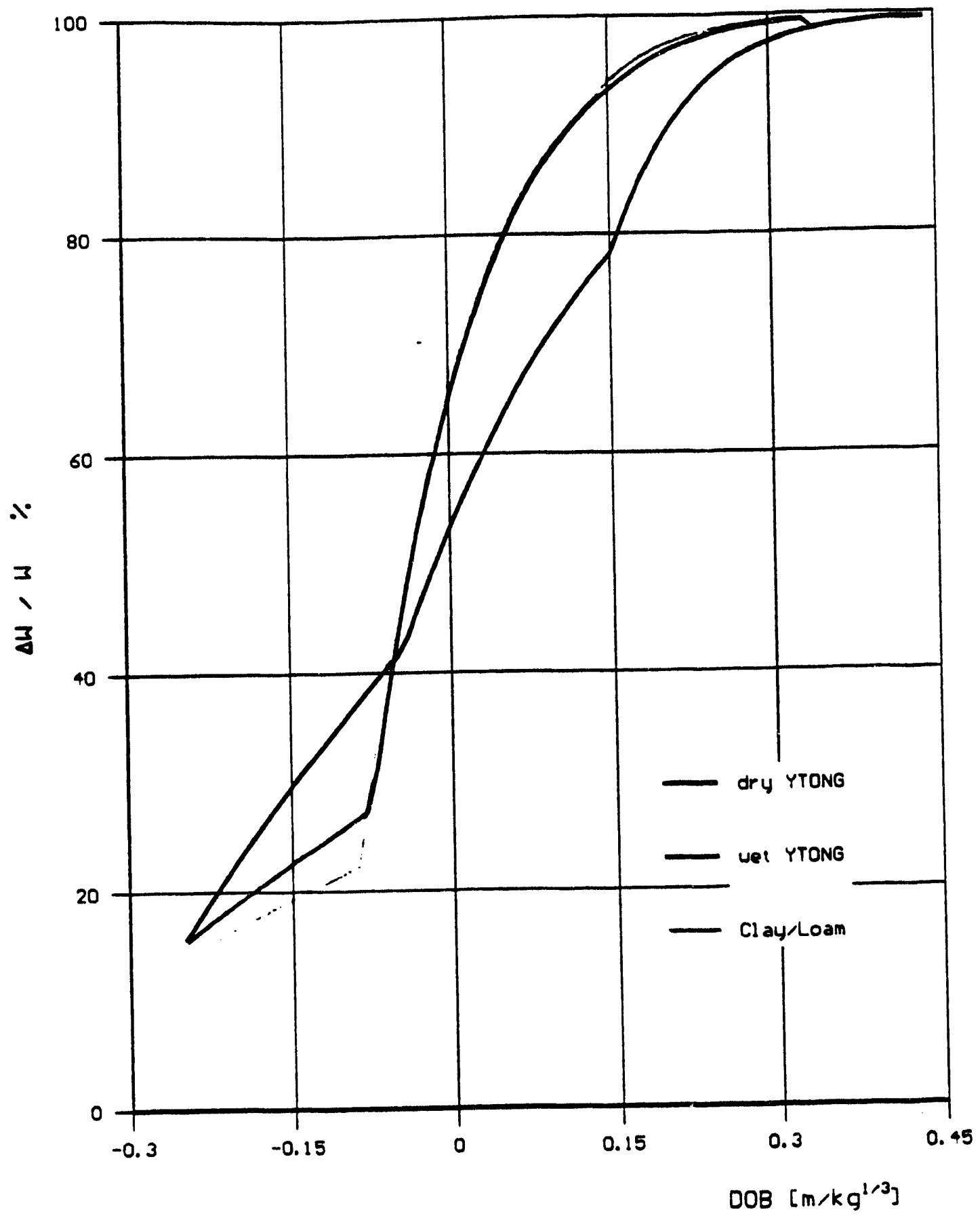

Figure 11a. Percentage of energy losses vs DOB at $G R=6\left[\mathrm{~m} / \mathrm{kg}^{1 / 3}\right]$ Polygon approximation 


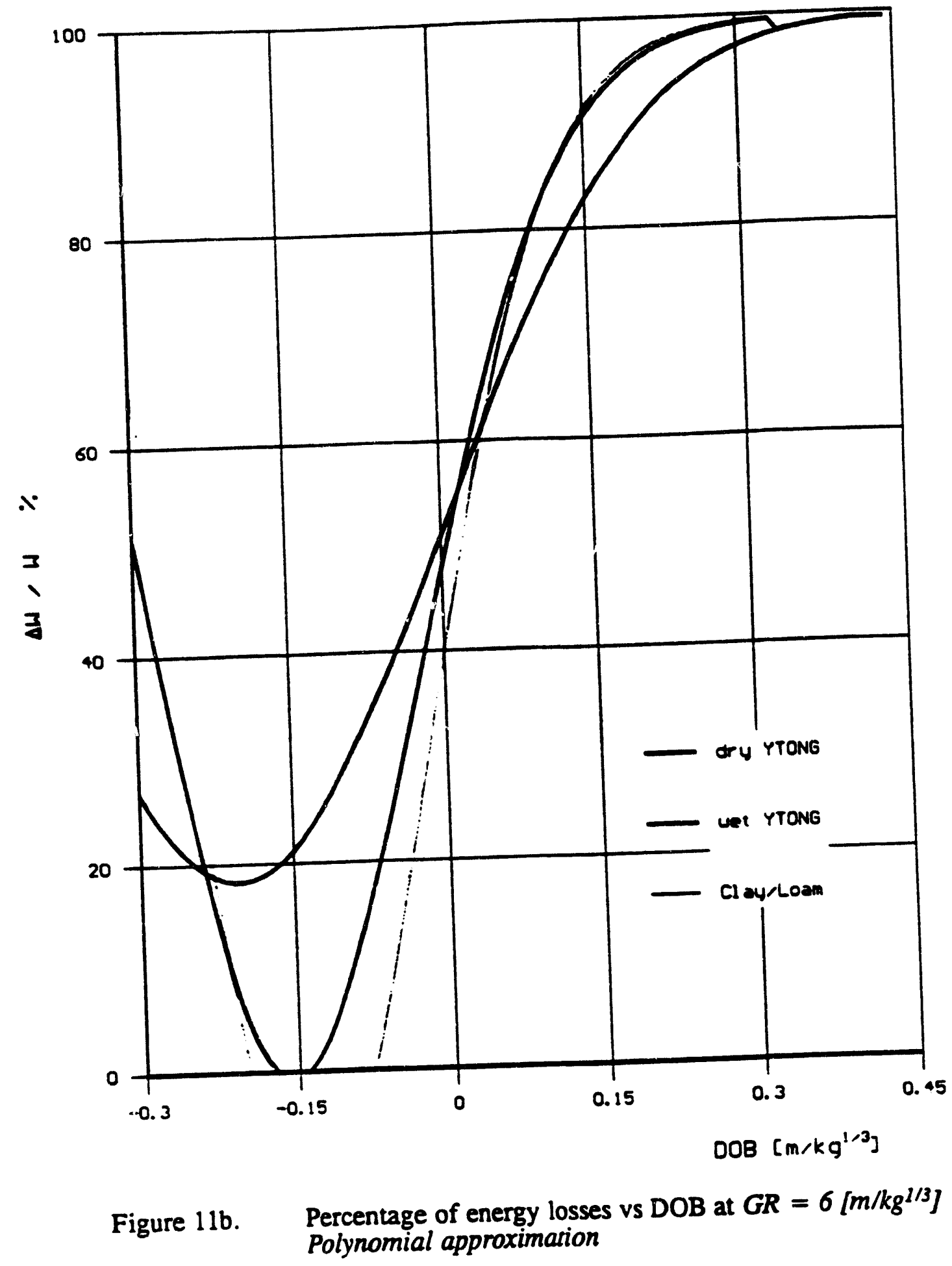




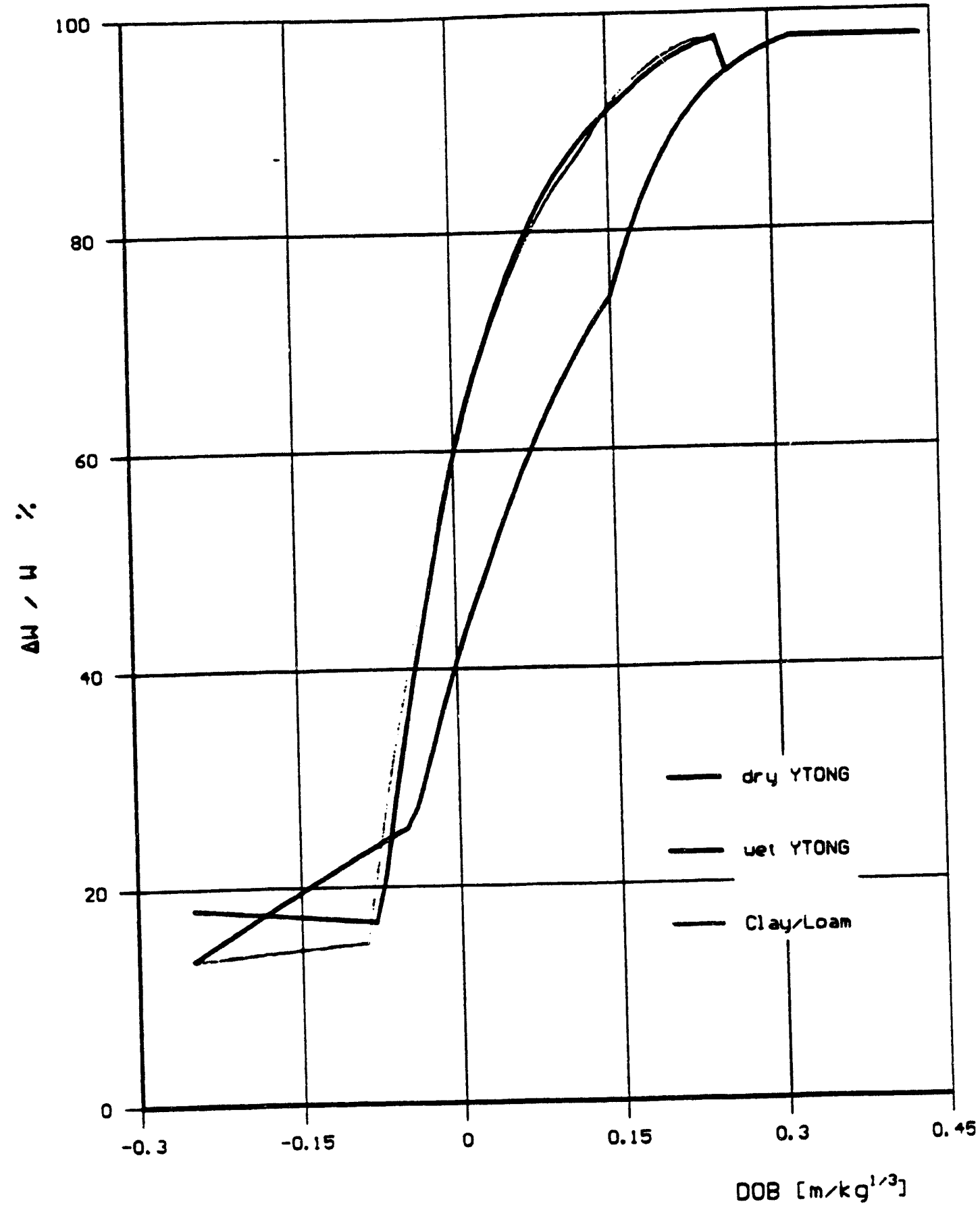

Figure 12a. Percentage of energy losses vs DOB at $G R=10\left[\mathrm{~m} / \mathrm{kg}^{1 / 3}\right]$ Polygon approximation 


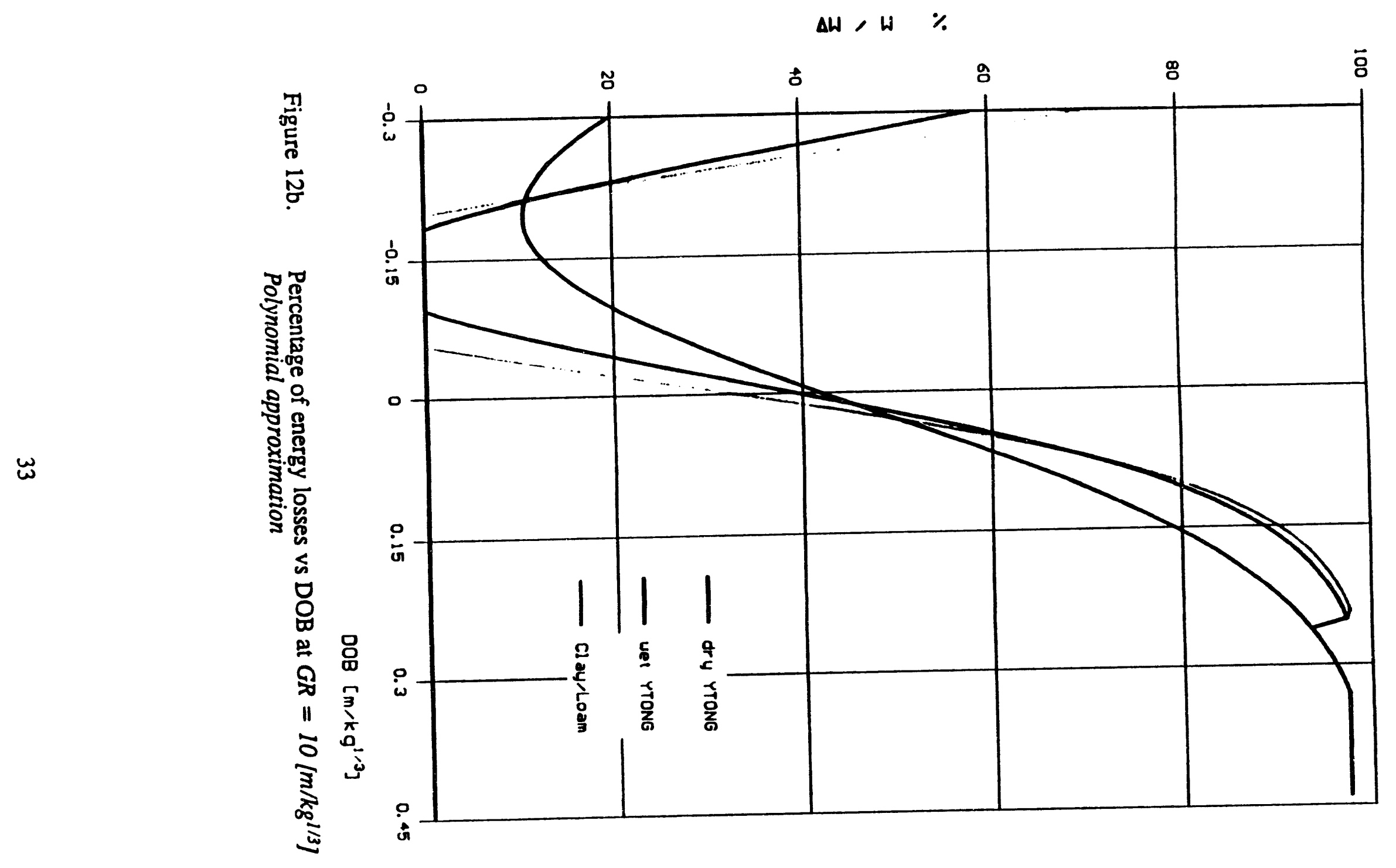



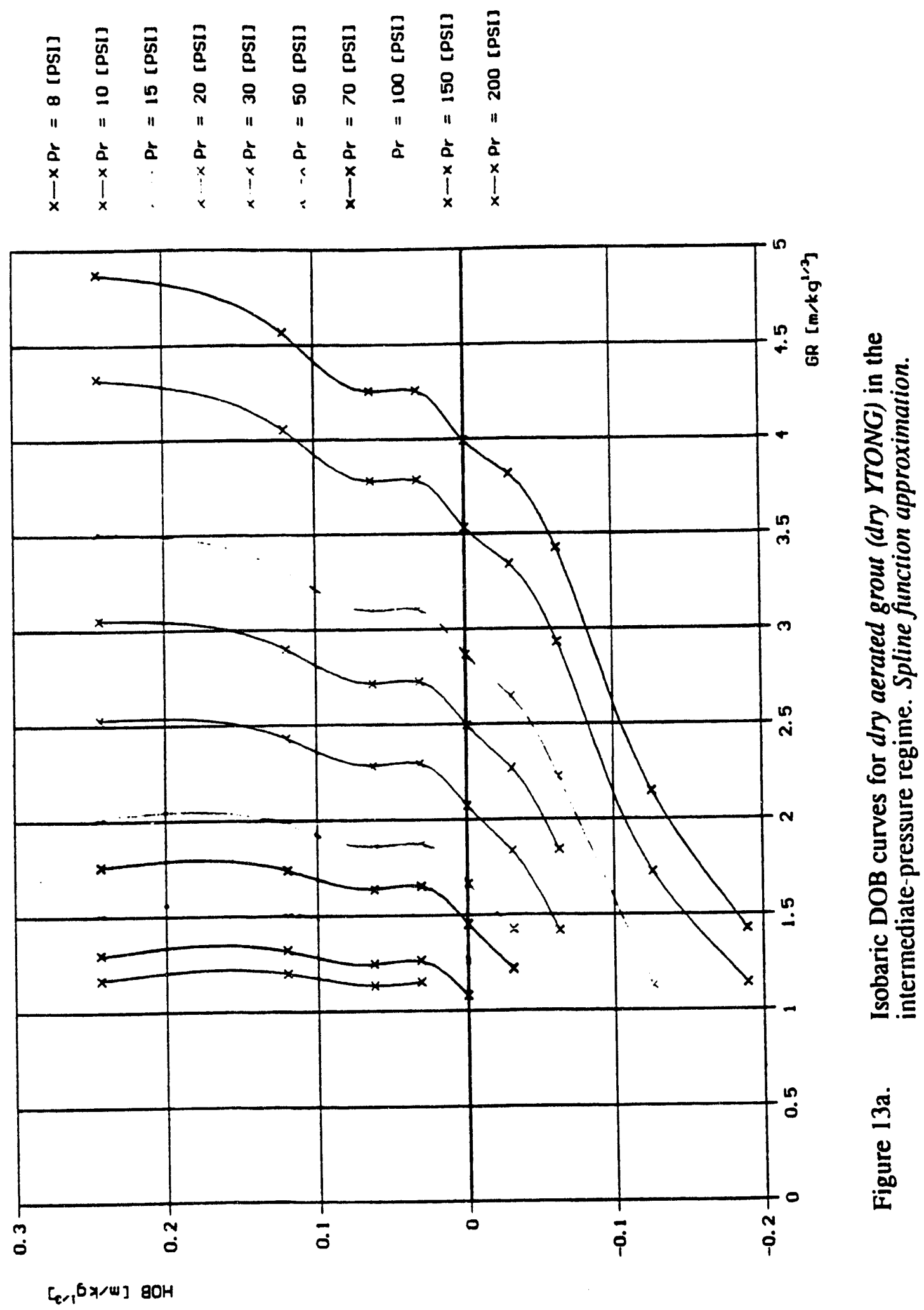

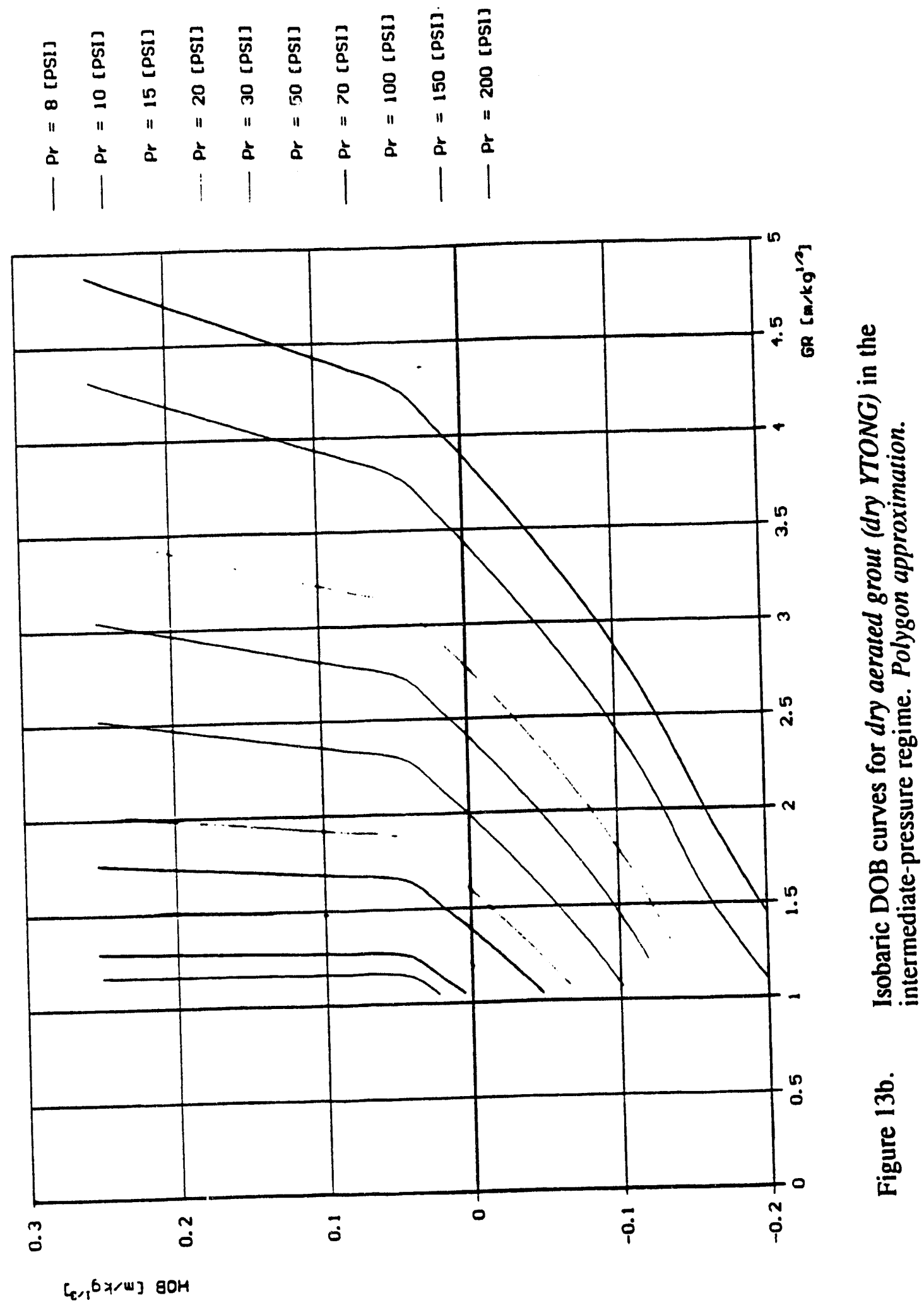


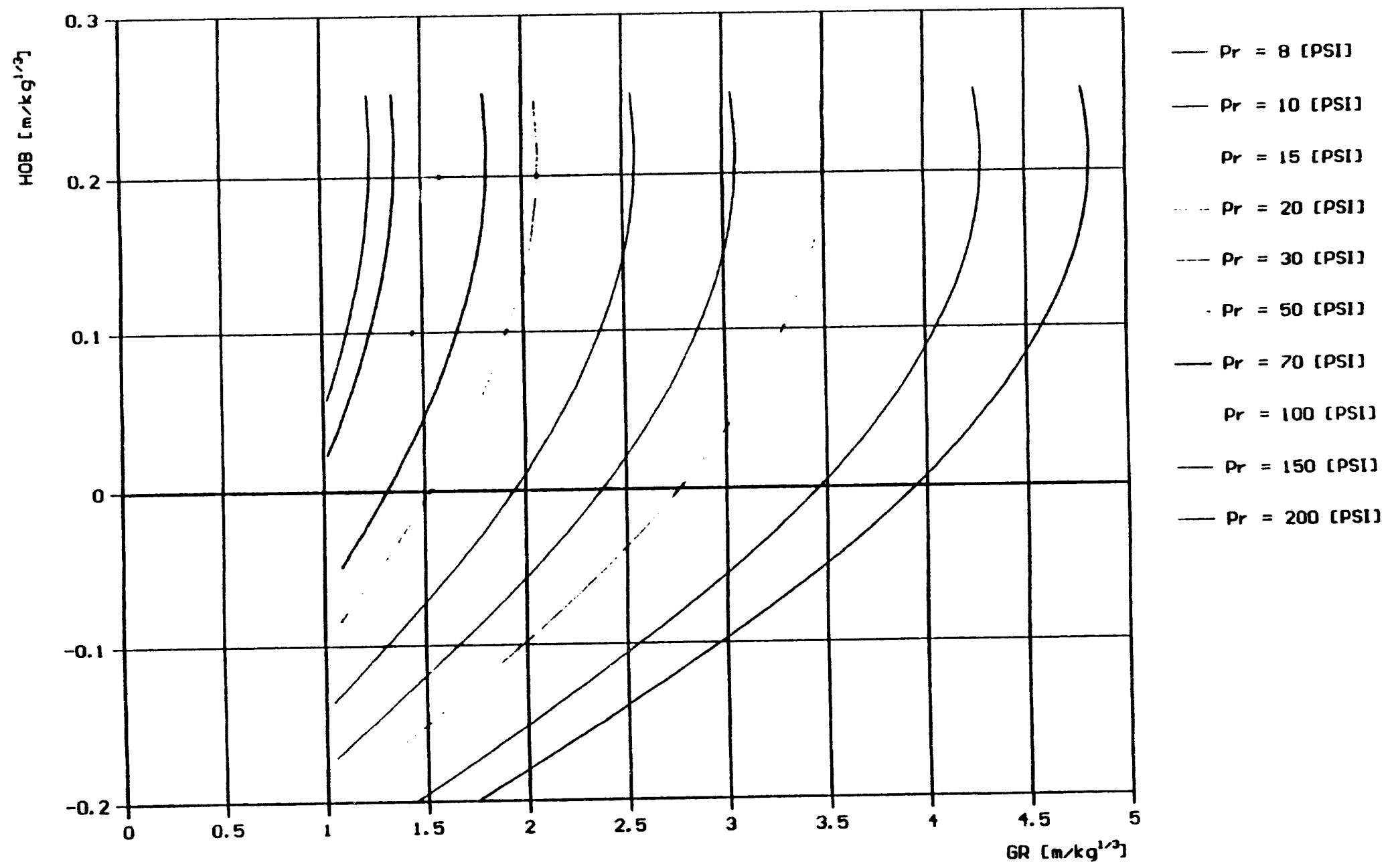

Figure 13c. Isobaric DOB curves for dry aerated grout (dry YTONG) in the intermediate-pressure regime. Polynomial approximation. 


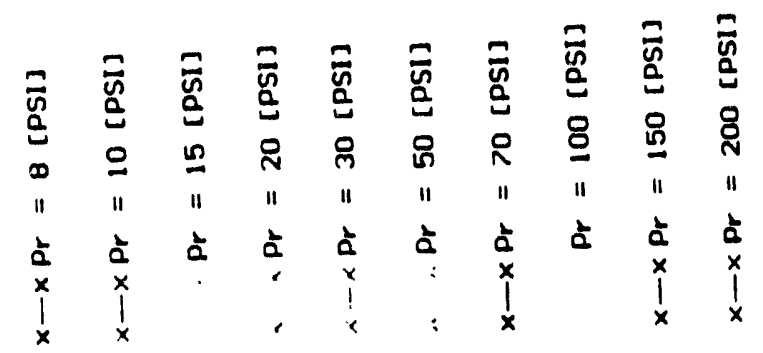

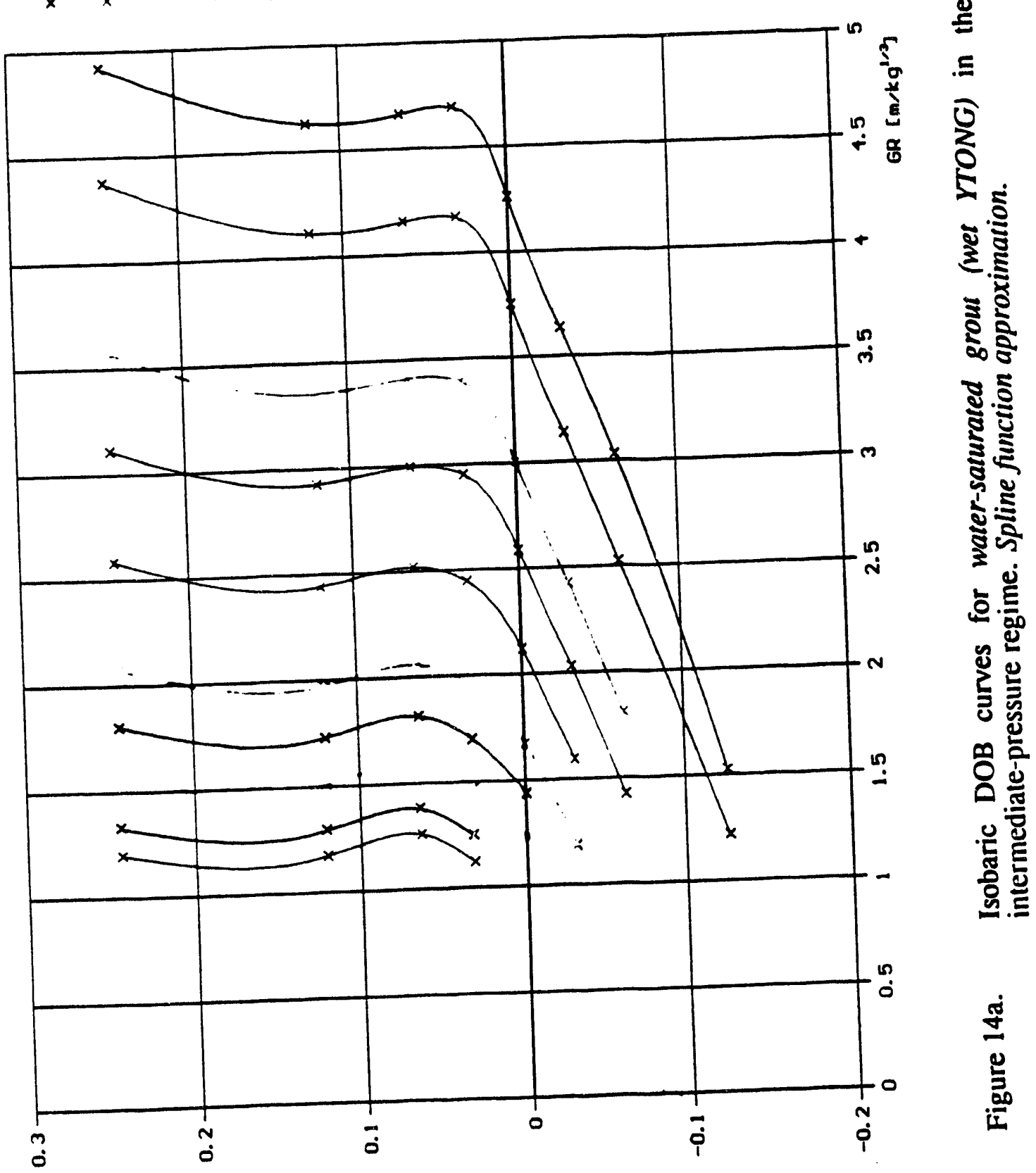

$[e, 16 x / w] 80 H$ 


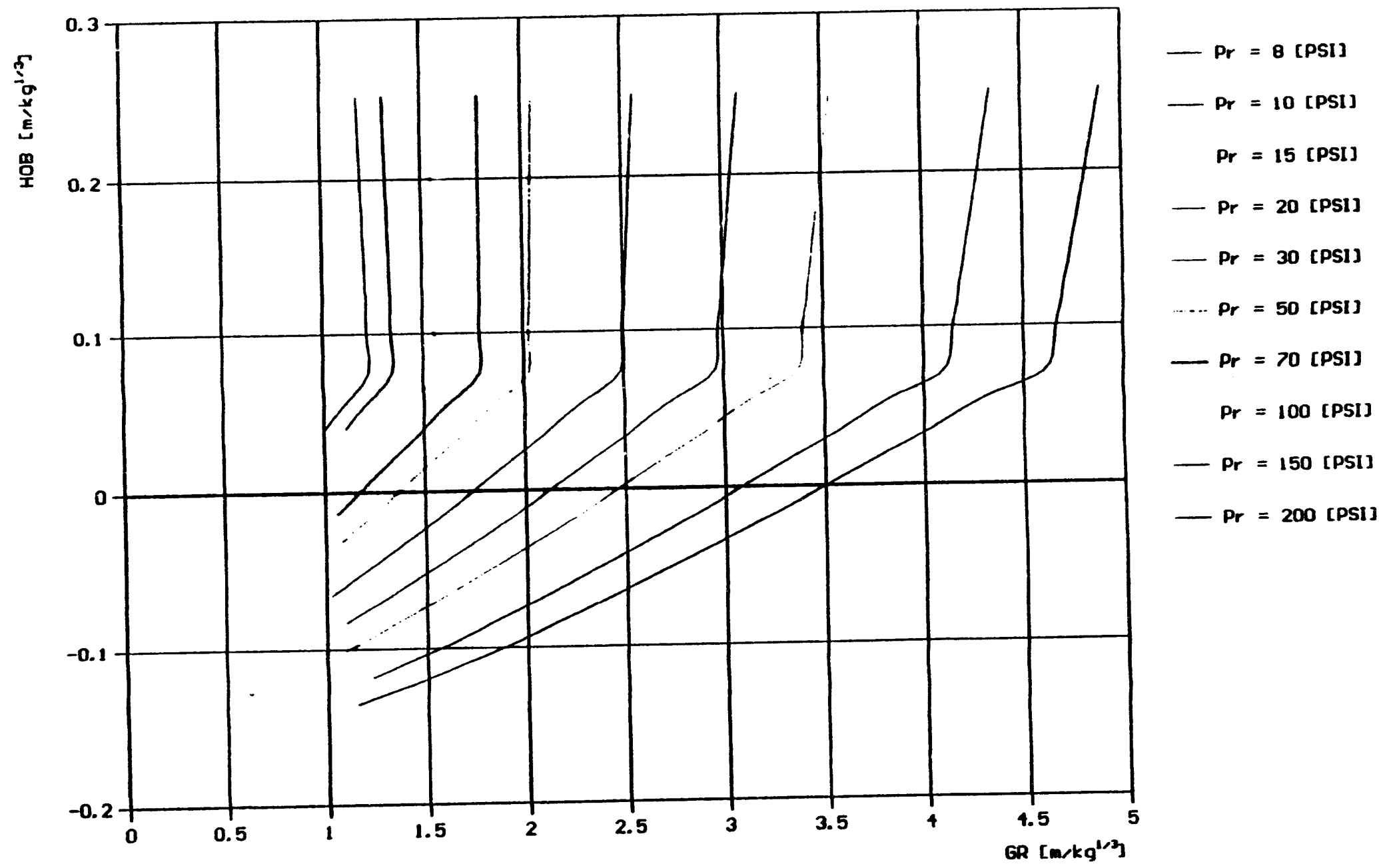

Figure 14b. Isobaric DOB curves for water-saturated grout (wet YTONG) in the intermediate-pressure regime. Polygon approximation. 


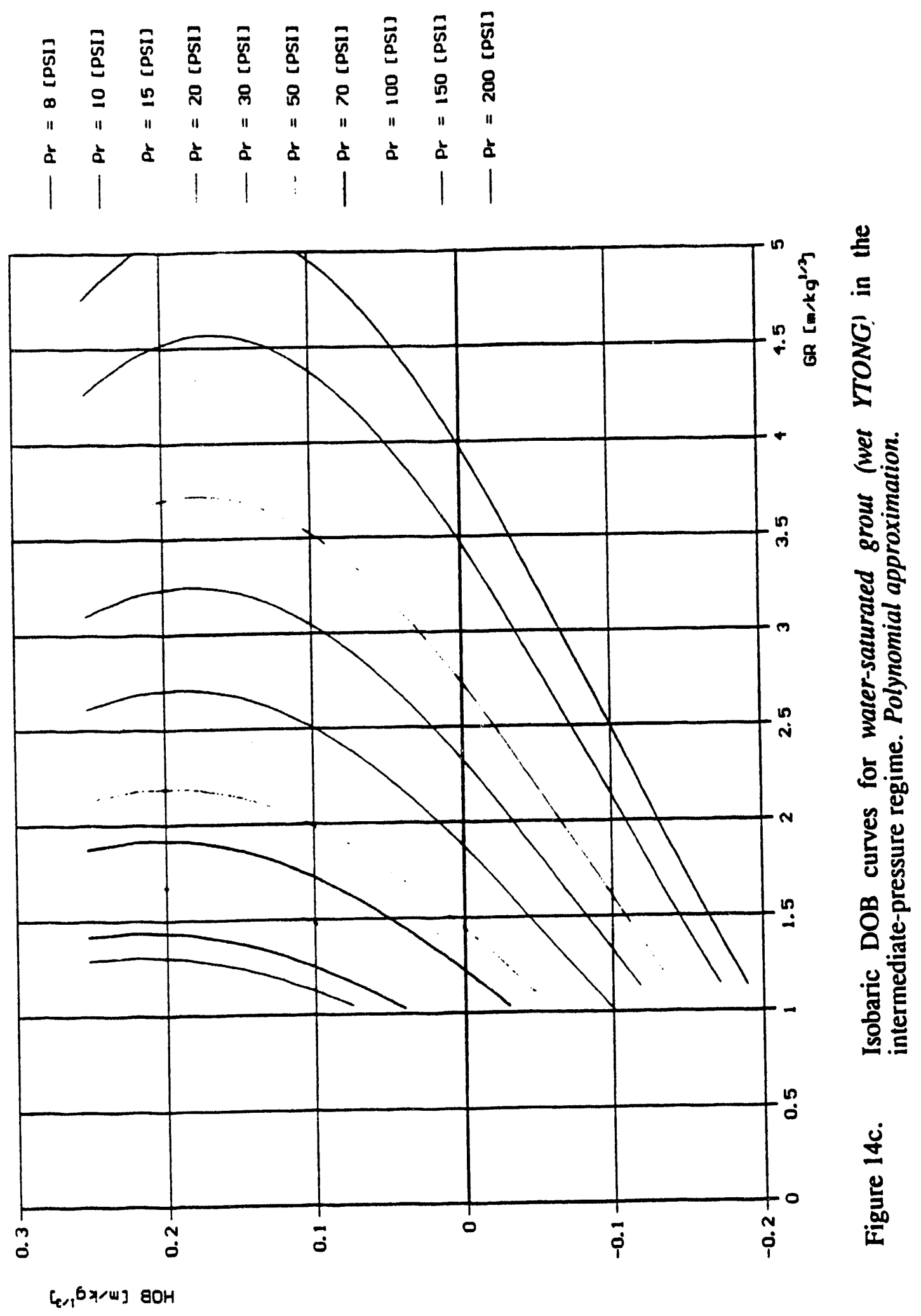




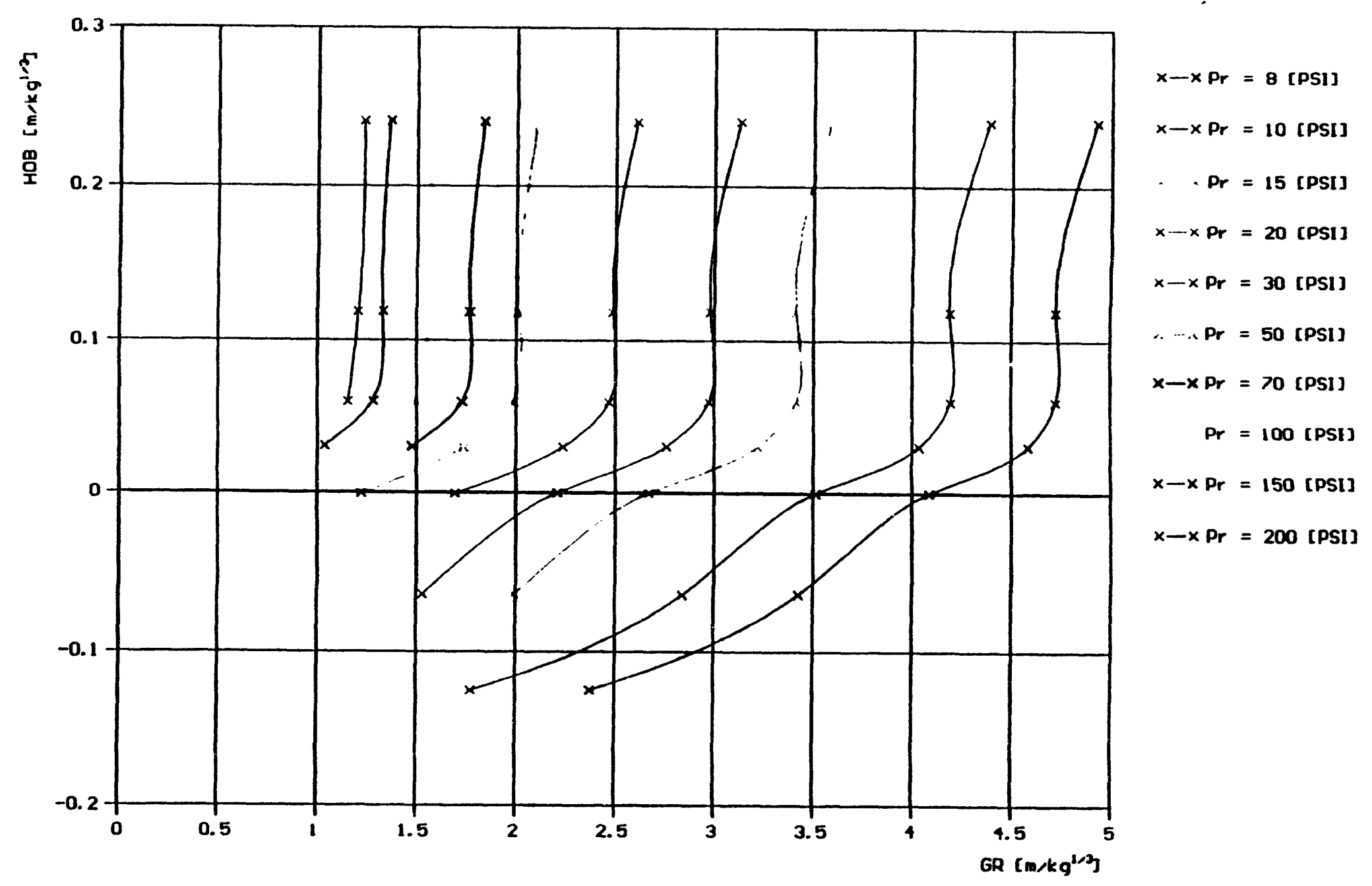

Figure 15a. Isobaric DOB curves for wet clay/loam in the intermediate-pressure regime.
Spline function approximation. 


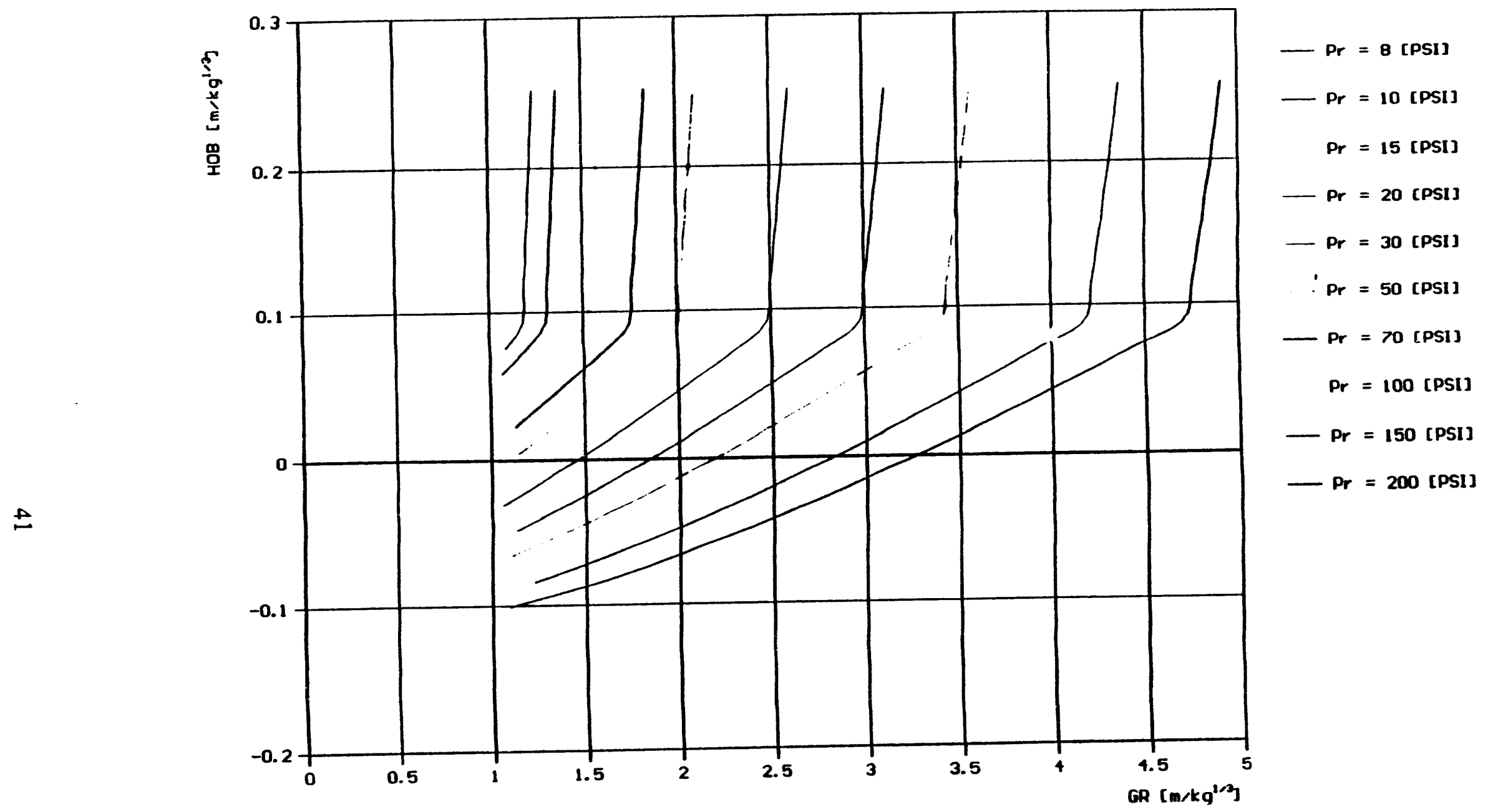

Figure 15b. Isobaric DOB curves for wet clay/loam in the intermediate-pressure regime. Polygon approximation. 


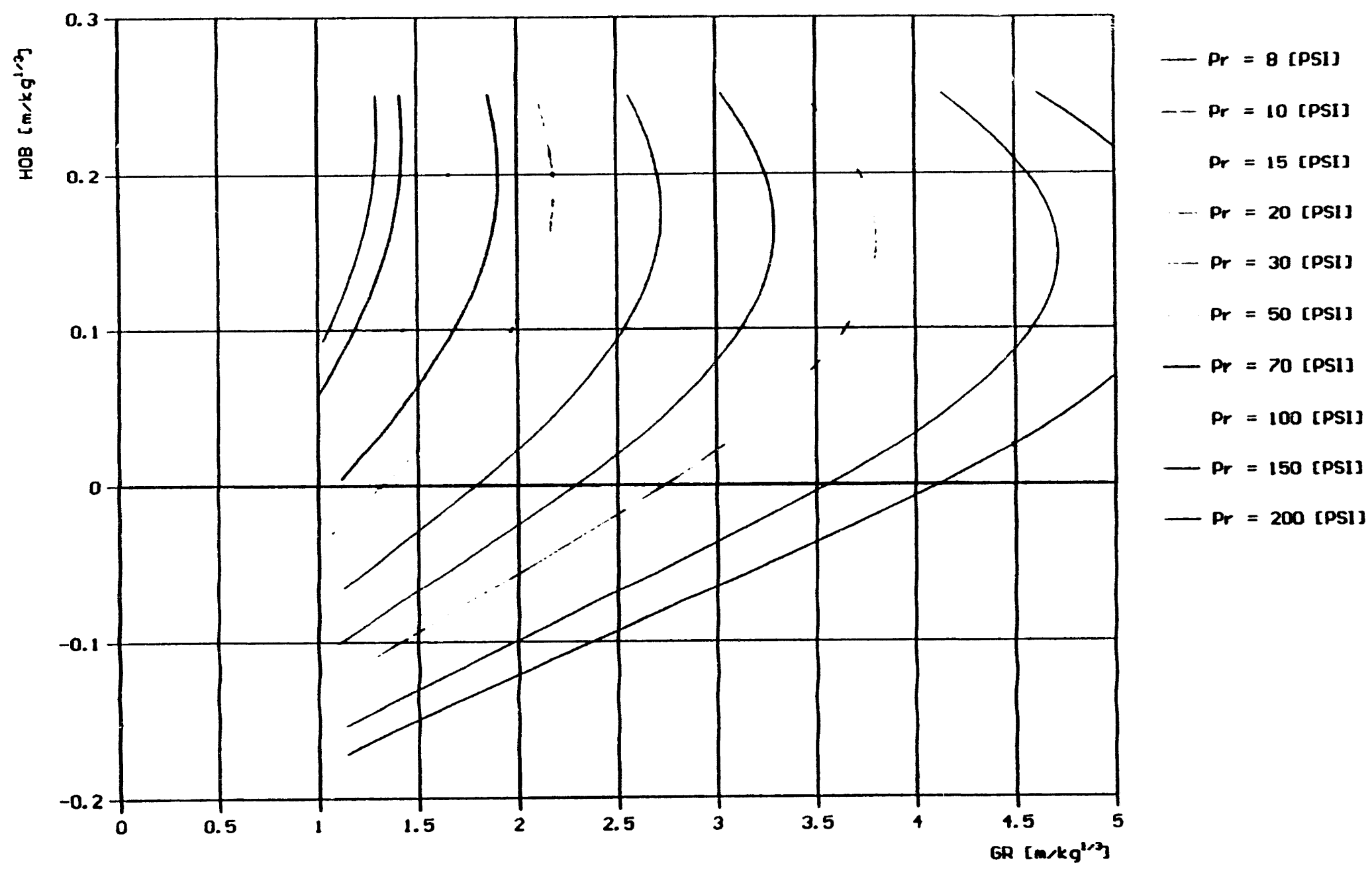

Figure 15c. Isobaric DOB curves for wet clay/loam in the intermediate-pressure regime. Polynomial approximation. 


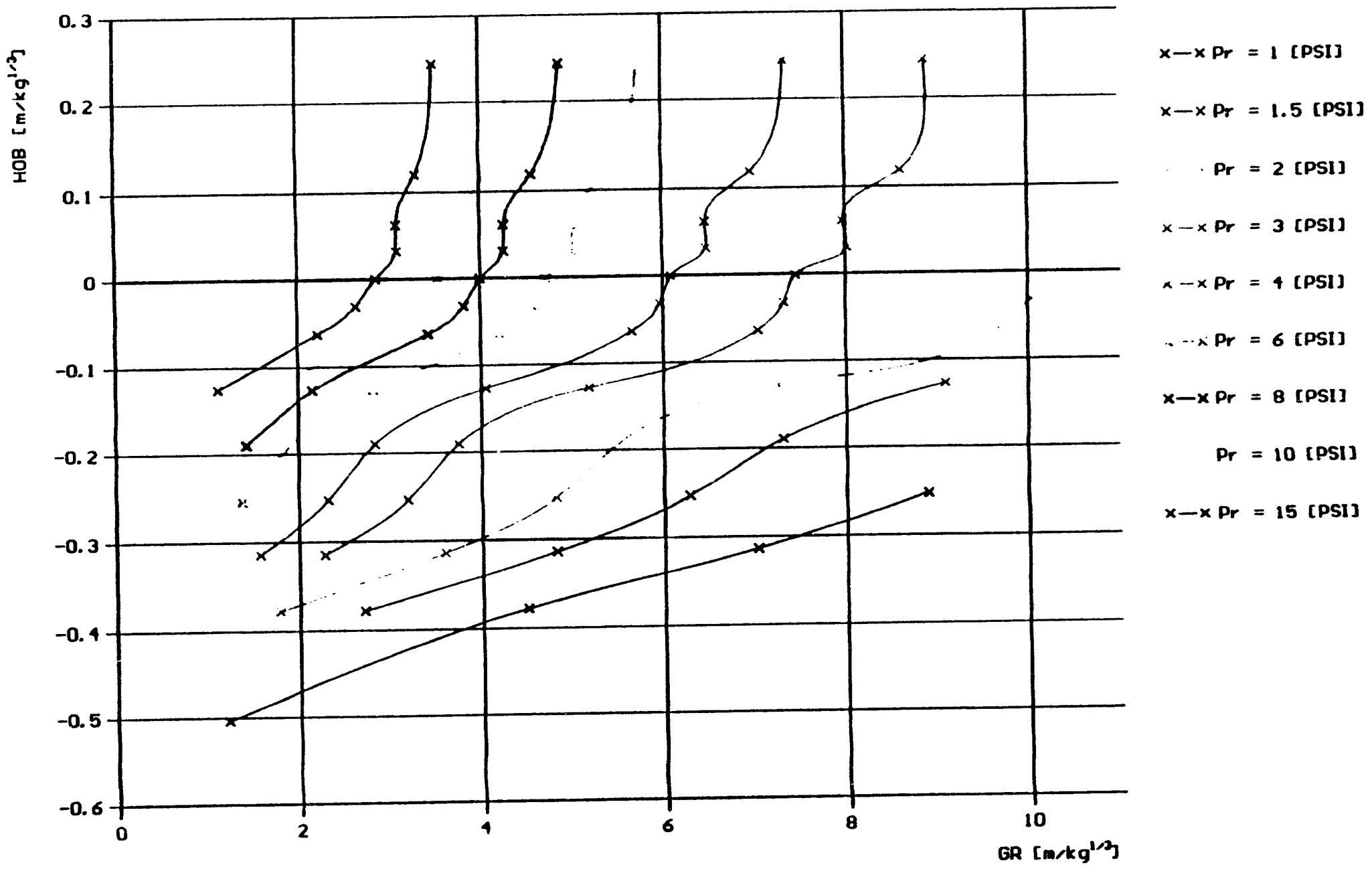

Figure 16a. Isobaric DOB curves for dry aerated grout (dry YTONG) in the low-pressure regime. Spline function approximation. 


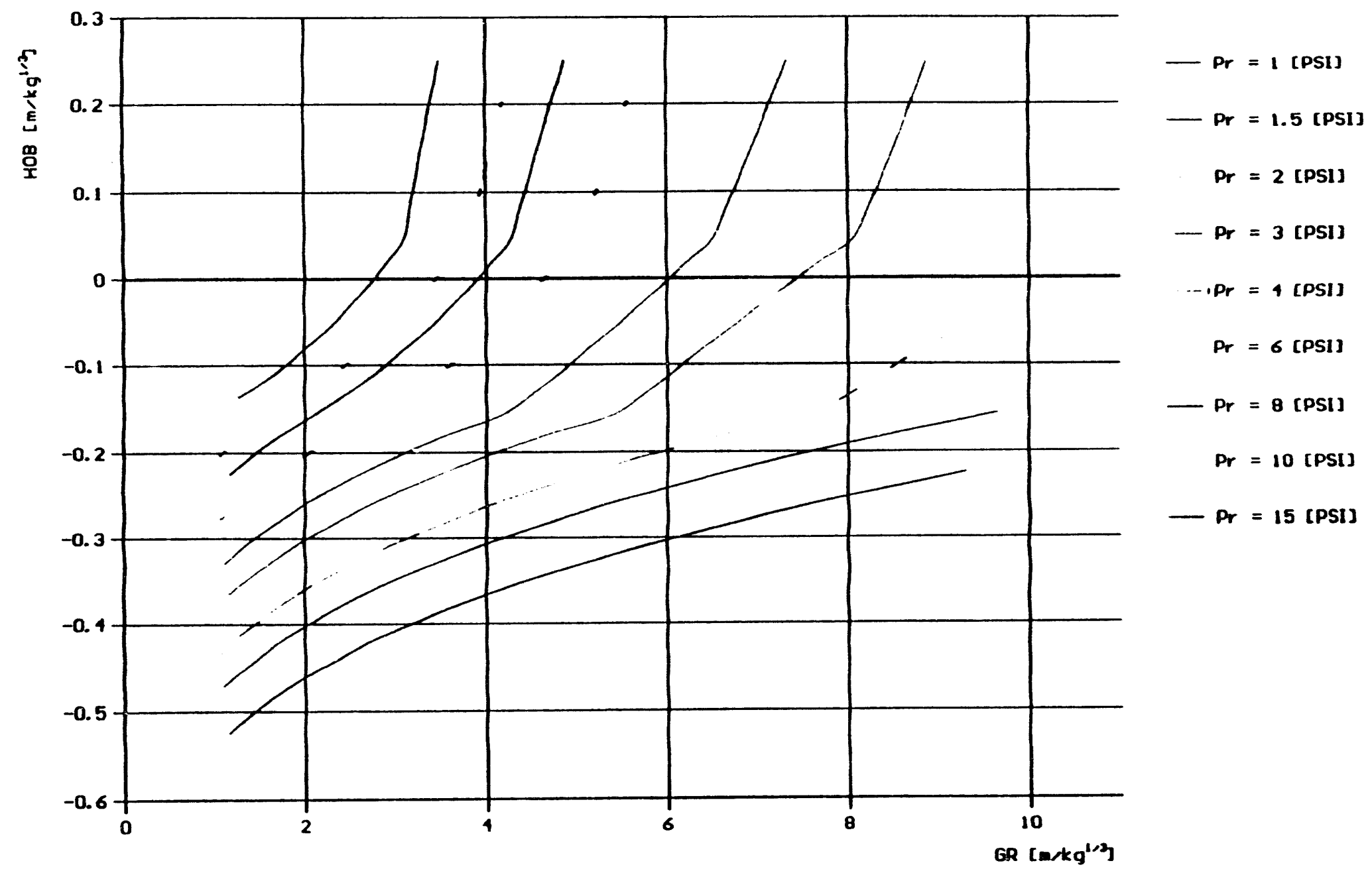

Figure 16b. Isobaric DOB curves for dry aerated grout (dry YTONG) in the low-pressure regime. Polygon approximation. 


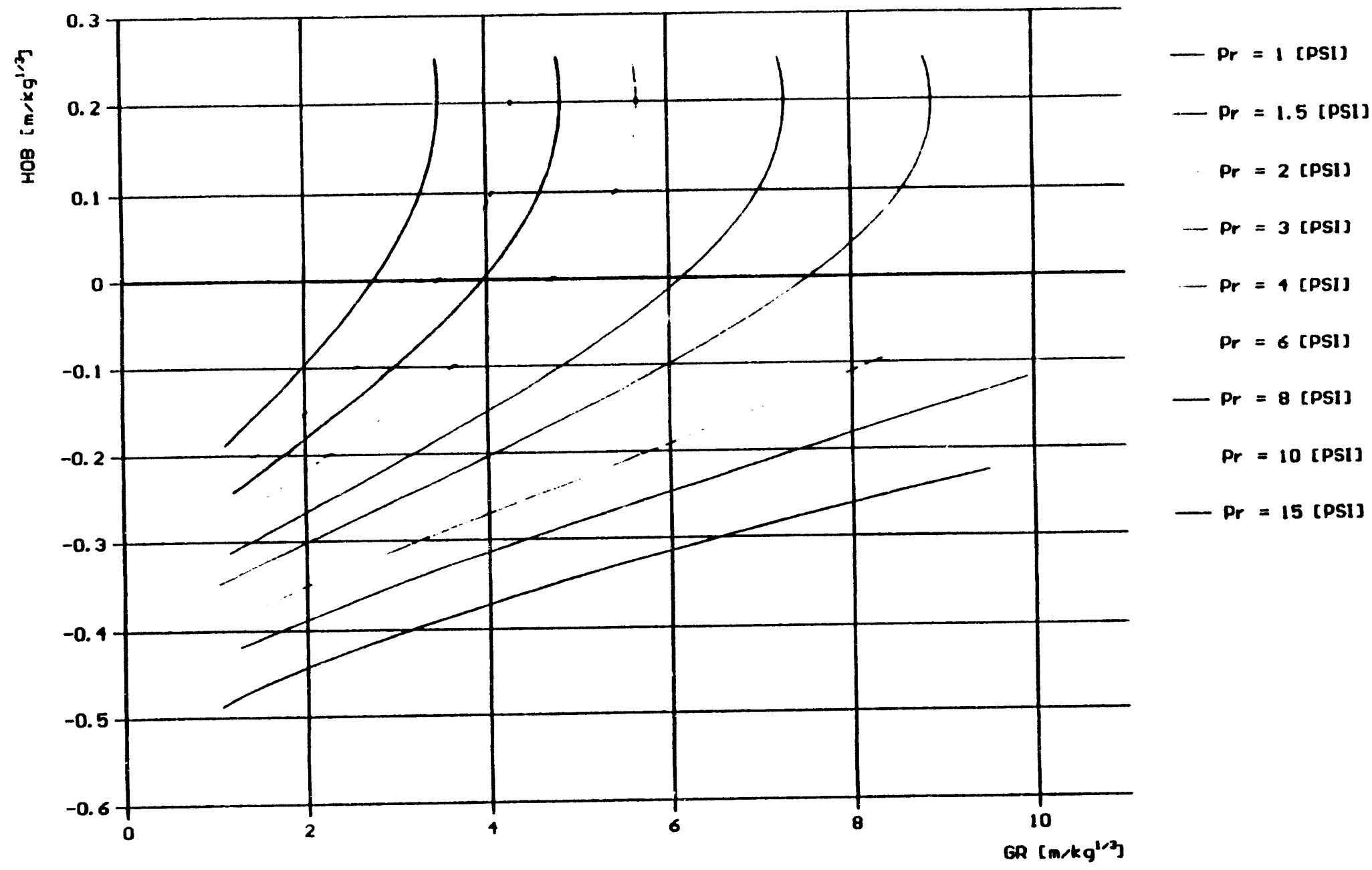

Figure 16c. Isobaric DOB curves for dry aerated grout (dry YTONG) in the low-pressure regime. Polynomial approximation. 

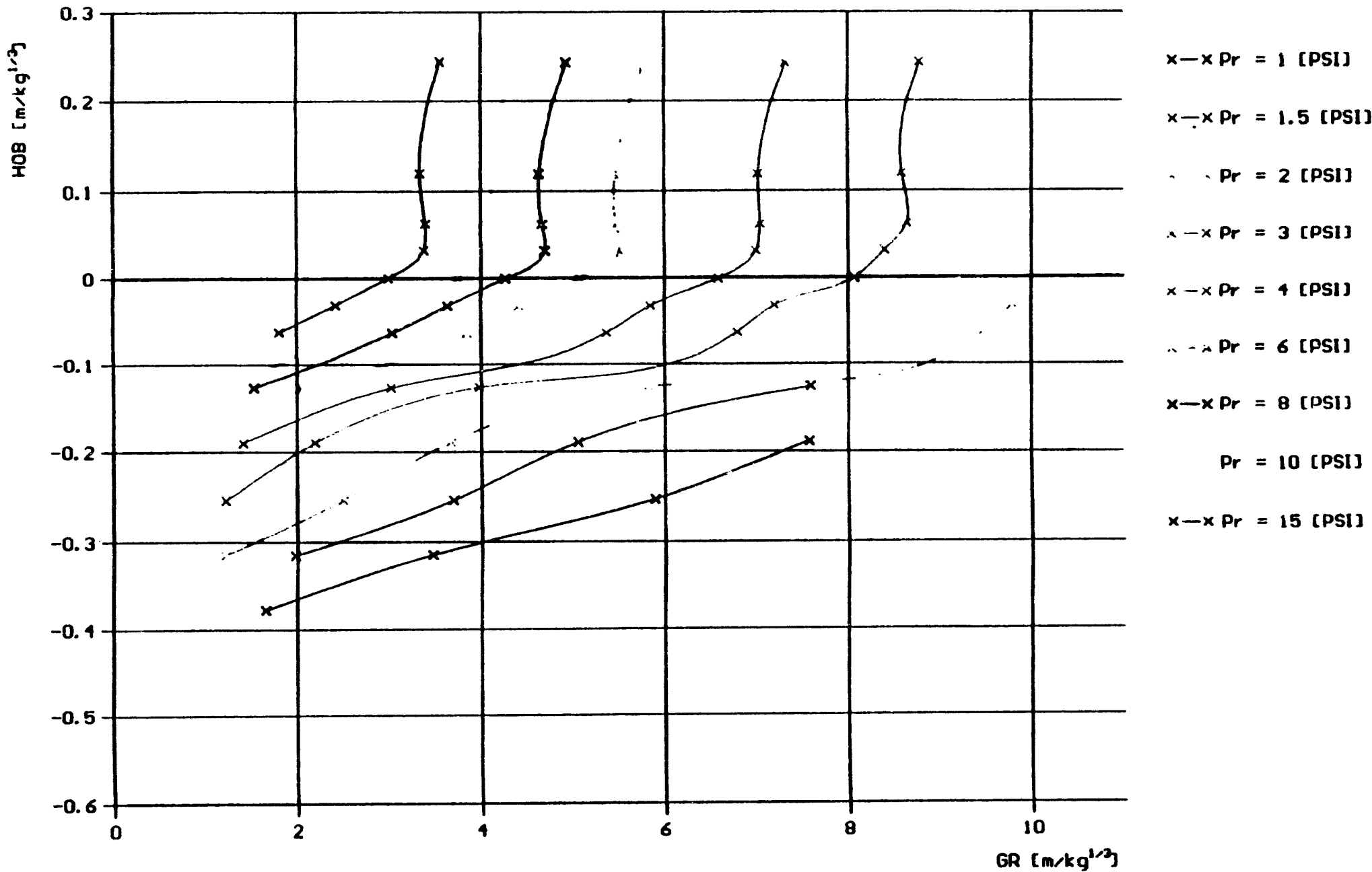

Figure 17a. Isobaric DOB curves for water-saturated grout (wet YTONG) in the low-pressure regime. Spline function approximation. 


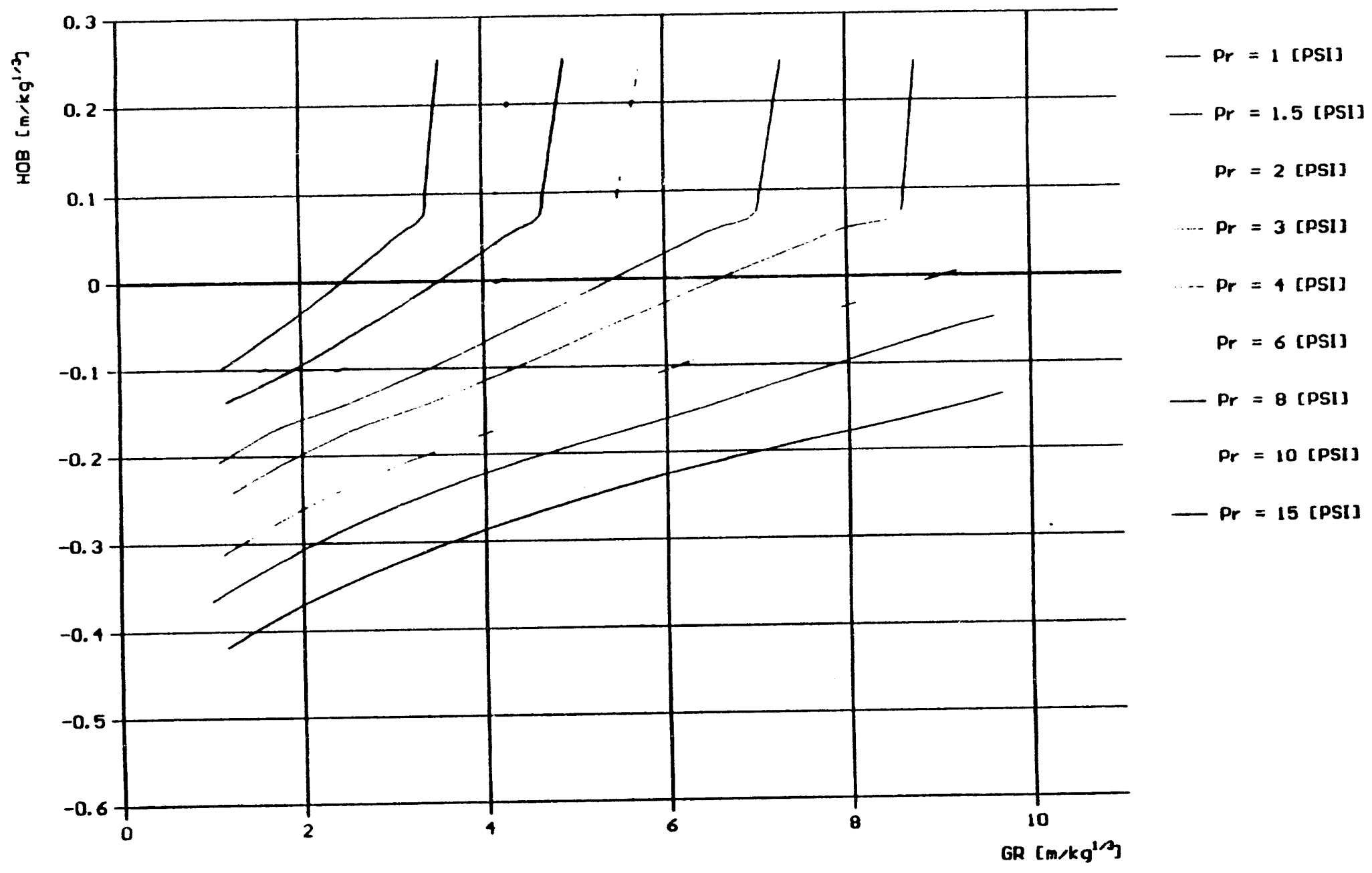

Figure 17b. Isobaric DOB curves for water-saturated grout (wet YTONG) in the low-pressure regime. Polygon approximation. 


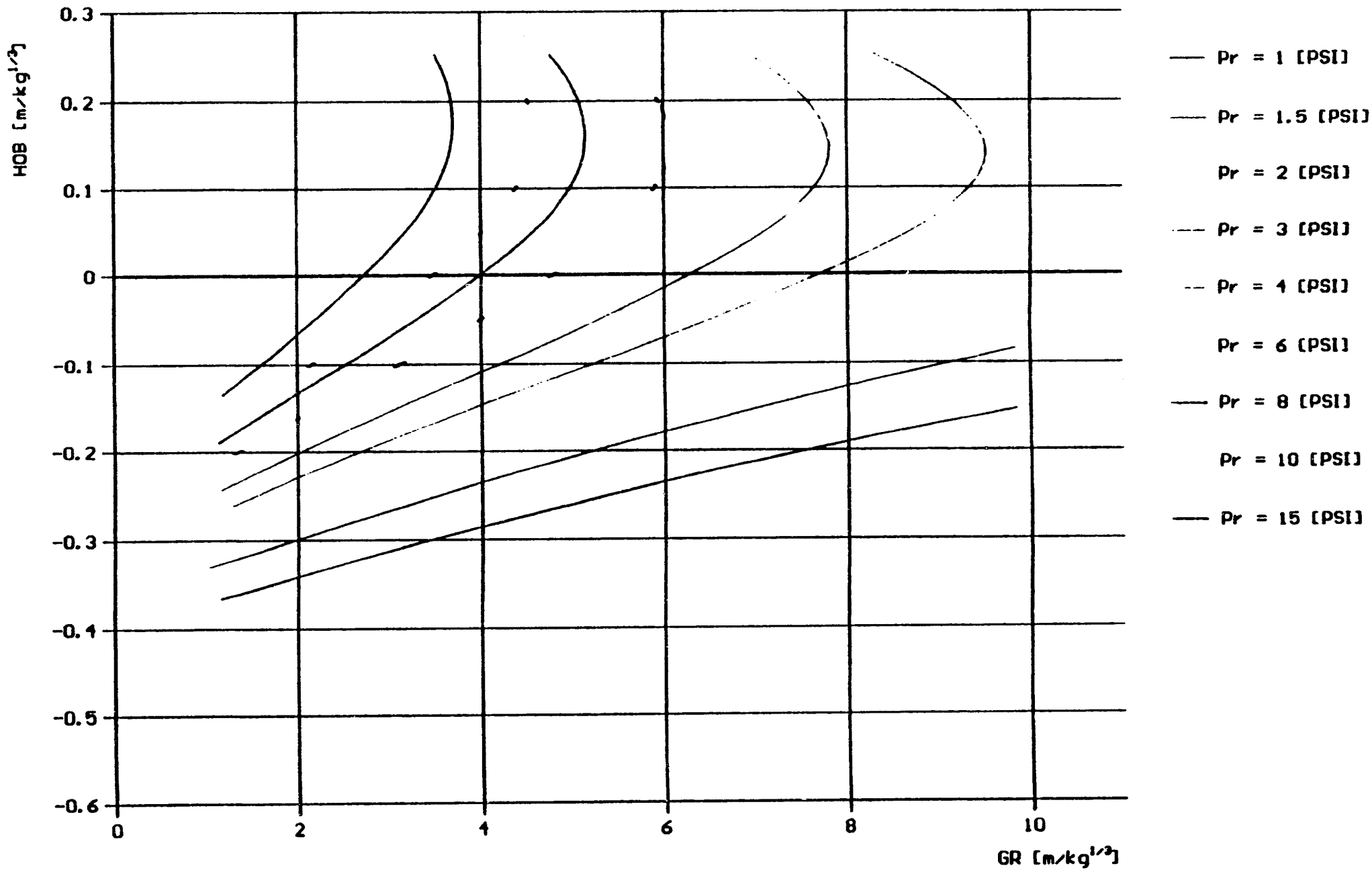

Figure 17c. Isobaric DOB curves for water-saturated grout (wet YTONG) in the low-pressure regime. Polynomial approximation. 


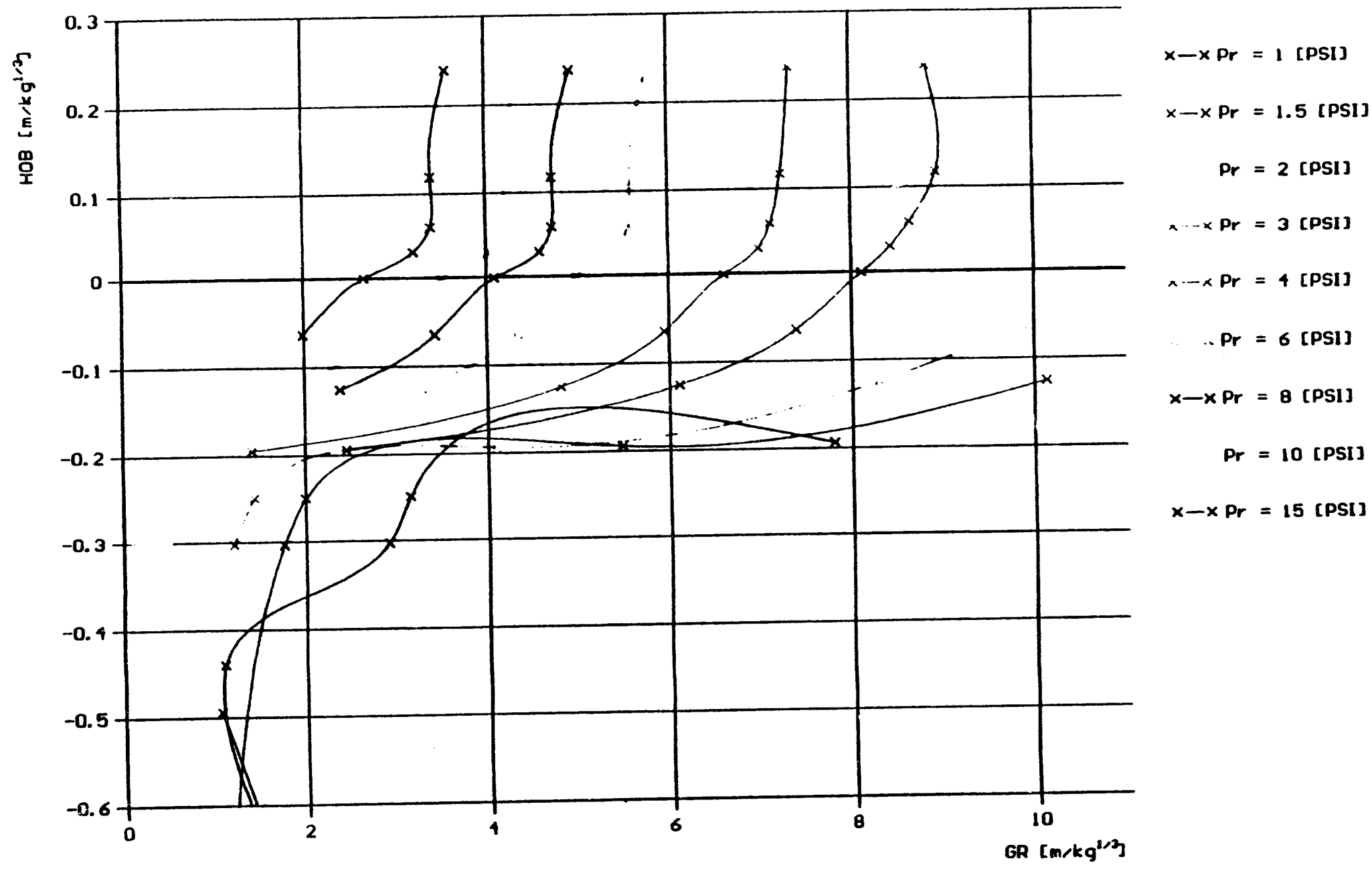

Figure 18a. Isobaric DOB curves for wet clay/loam in the low-pressure regime. Spline function approximation. 


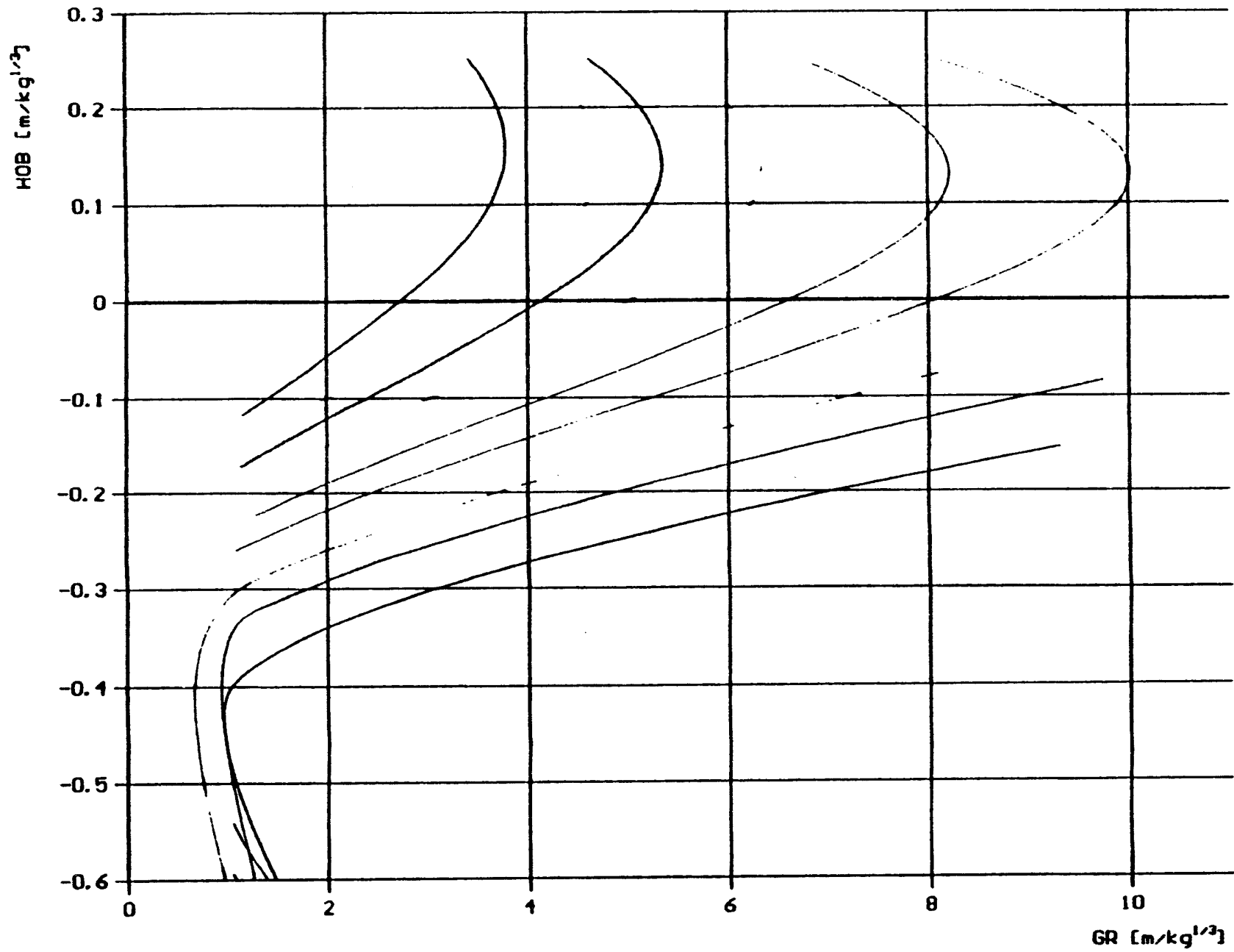

$-\operatorname{Pr}=1[\mathrm{PSI}]$

$-P_{r}=1.5[P S 1]$

$\operatorname{Pr}=2[$ PSI $]$

Pr $=3$ [PSI]

$-\operatorname{Pr}=4[\mathrm{PSI}]$

$\operatorname{Pr}=6[\mathrm{PSI}]$

$-\operatorname{Pr}=8$ [PS1]

$\operatorname{Pr}=10[\mathrm{PSI}]$

$-\operatorname{Pr}=15$ [PSI]

Figure 18b. Isobaric DOB curves for wet clay/loam in the low-pressure regime. Polygon approximation. 


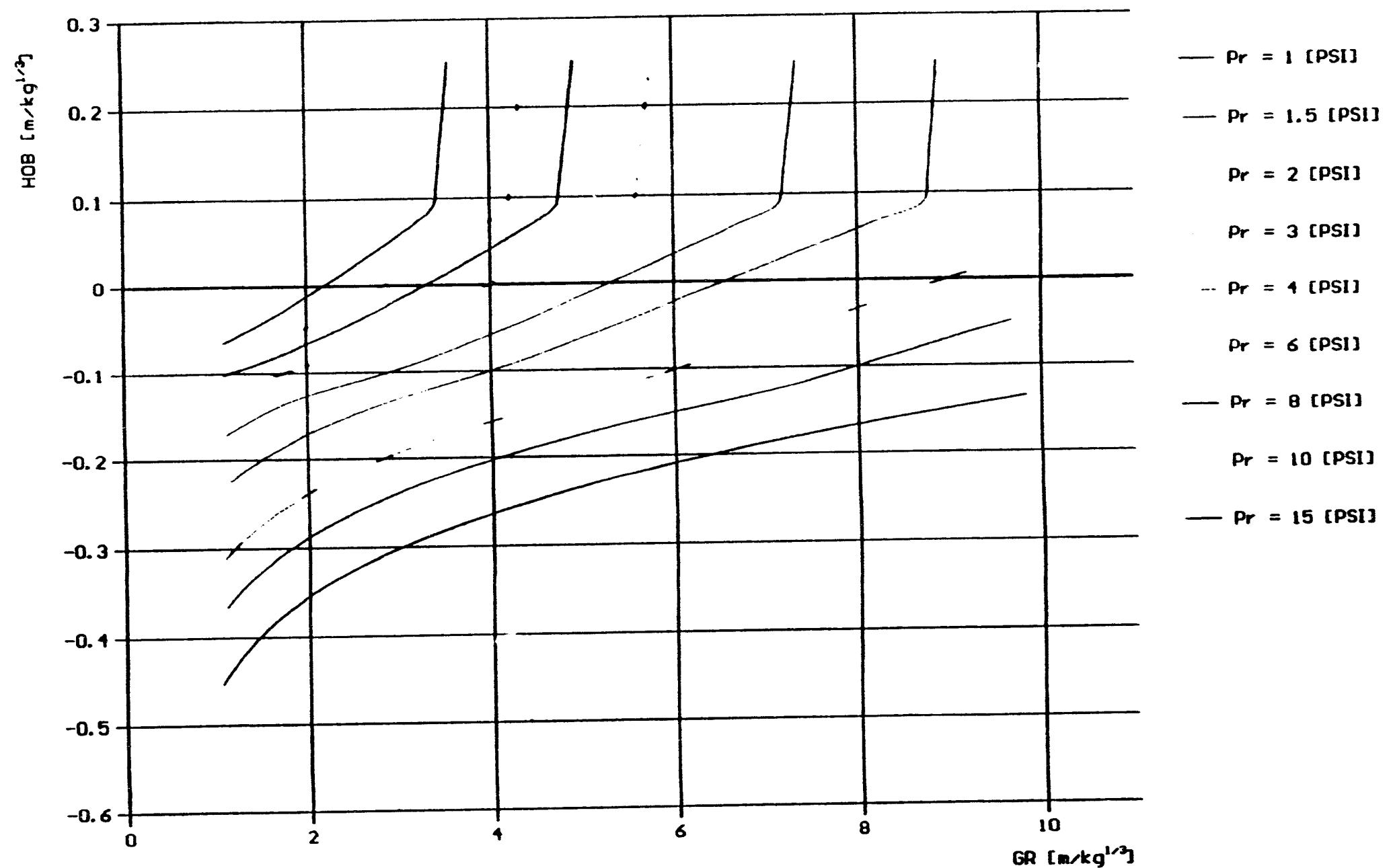

Figure 18c. Isobaric DOB curves for wet clay/loam in the low-pressure regime. Polynomial approximation. 


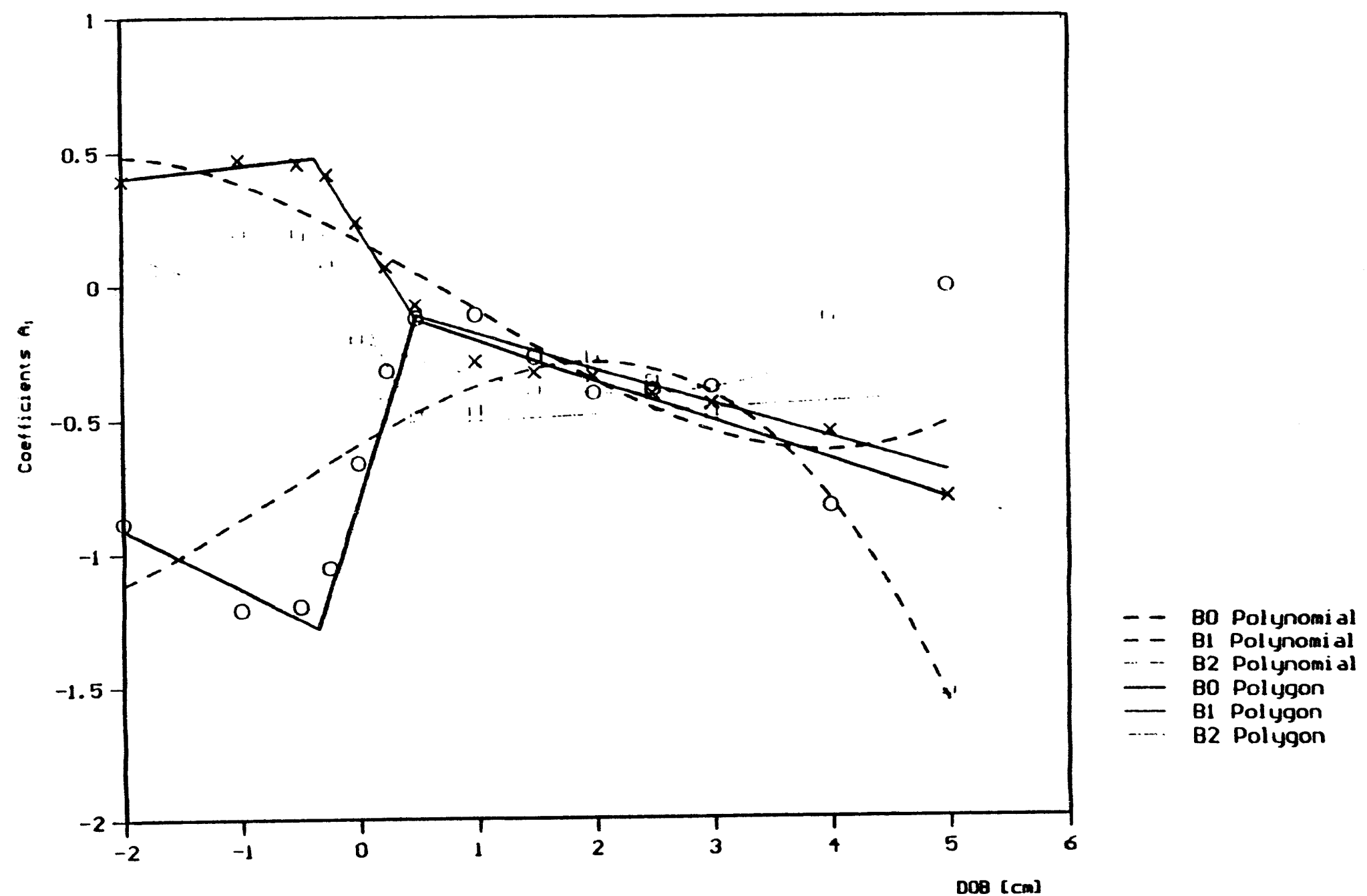

Figure 19. Coefficients of approximation functions for overpressure impulse vs ground range at different $\mathrm{DOB}$. Aerated grout (dry YTONG); polynomial and polygon approximation 


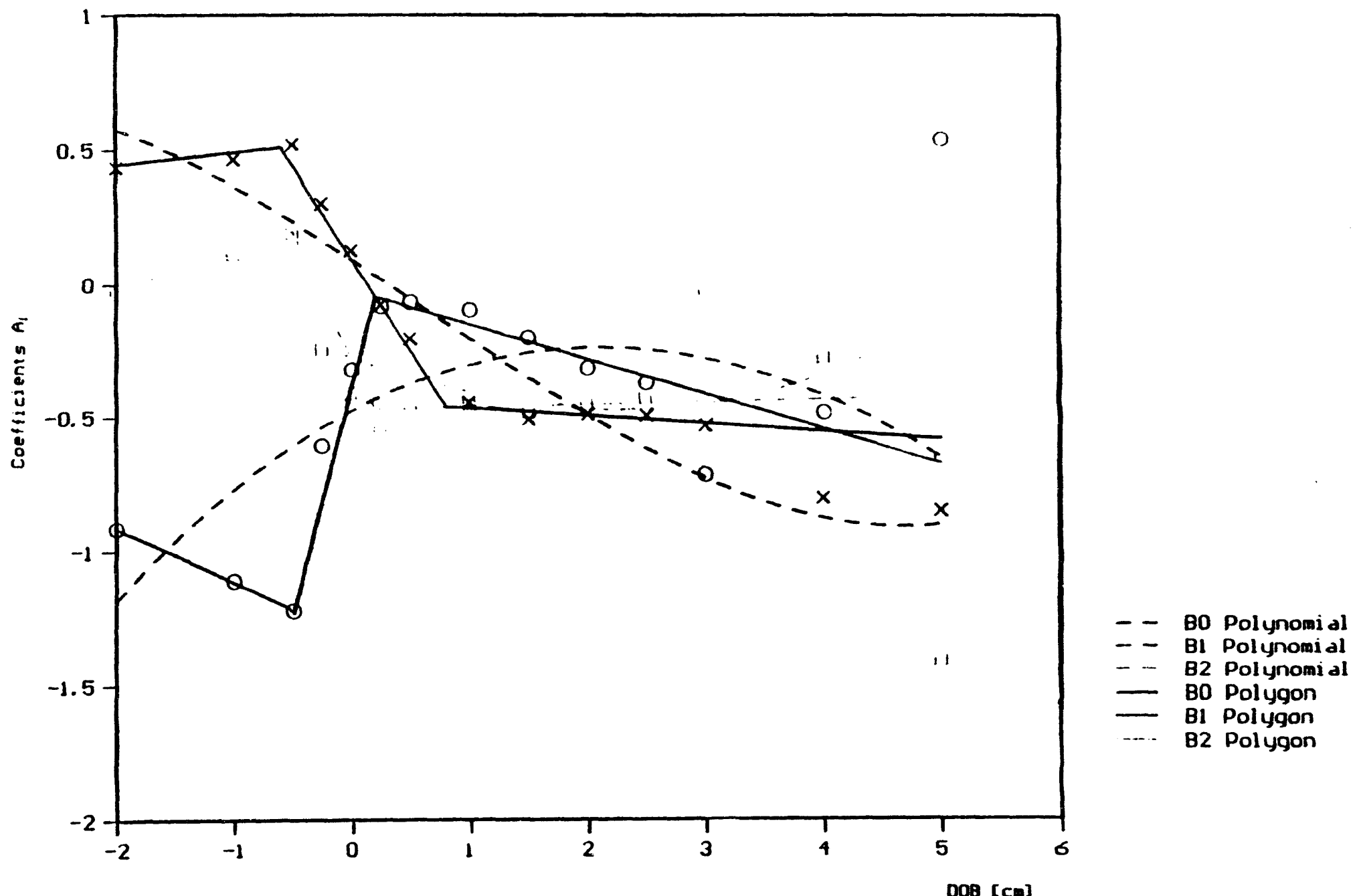

Figure 20. Coefficients of approximation functions for overpressure impulse vs ground range at different DOB.

Water-saturated grout (wet YTONG); polynomial and polygon approximation 


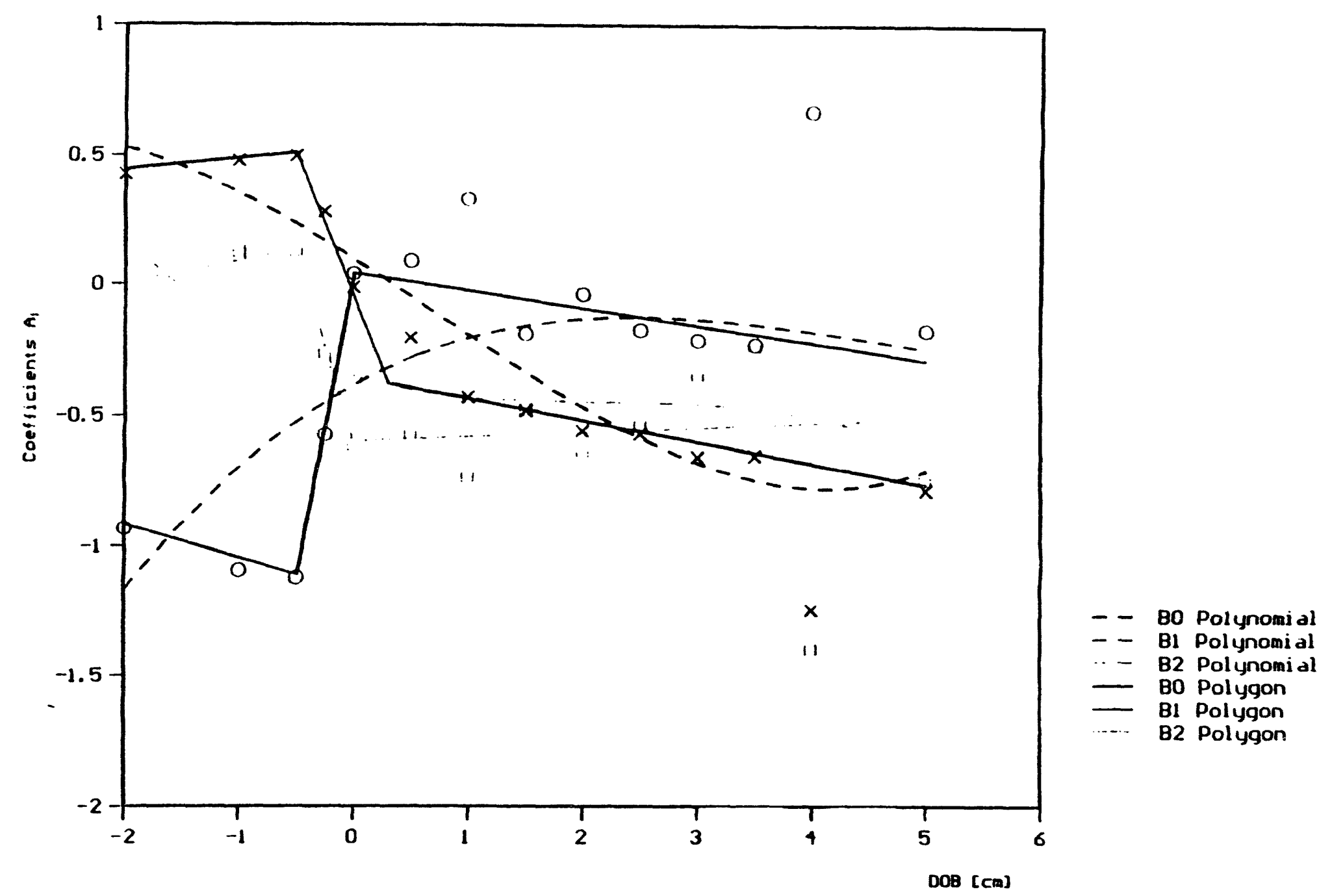

Figure 21. Coefficients of approximation functions for overpressure impulse vs ground range at different DOB.

Wet clay/loam; polynomial and polygon approximation 

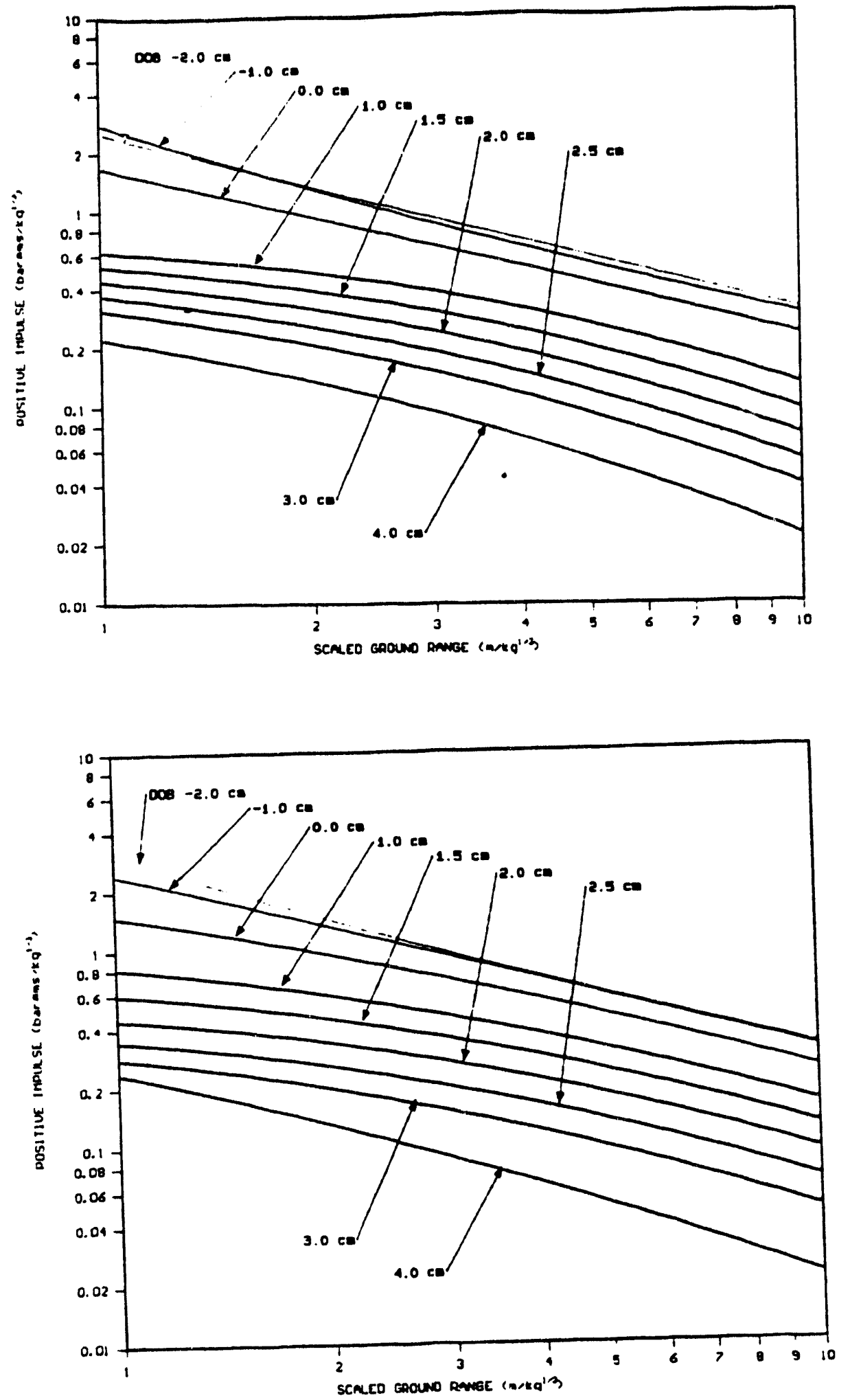

Figure 22. Overpressure-impulse vs ground-range curves for different DOB. Aerated grout (dry YTONG)

$\begin{array}{ll}\text { (a) polygon approximation } & \text { (b) polynomial approximation }\end{array}$ 

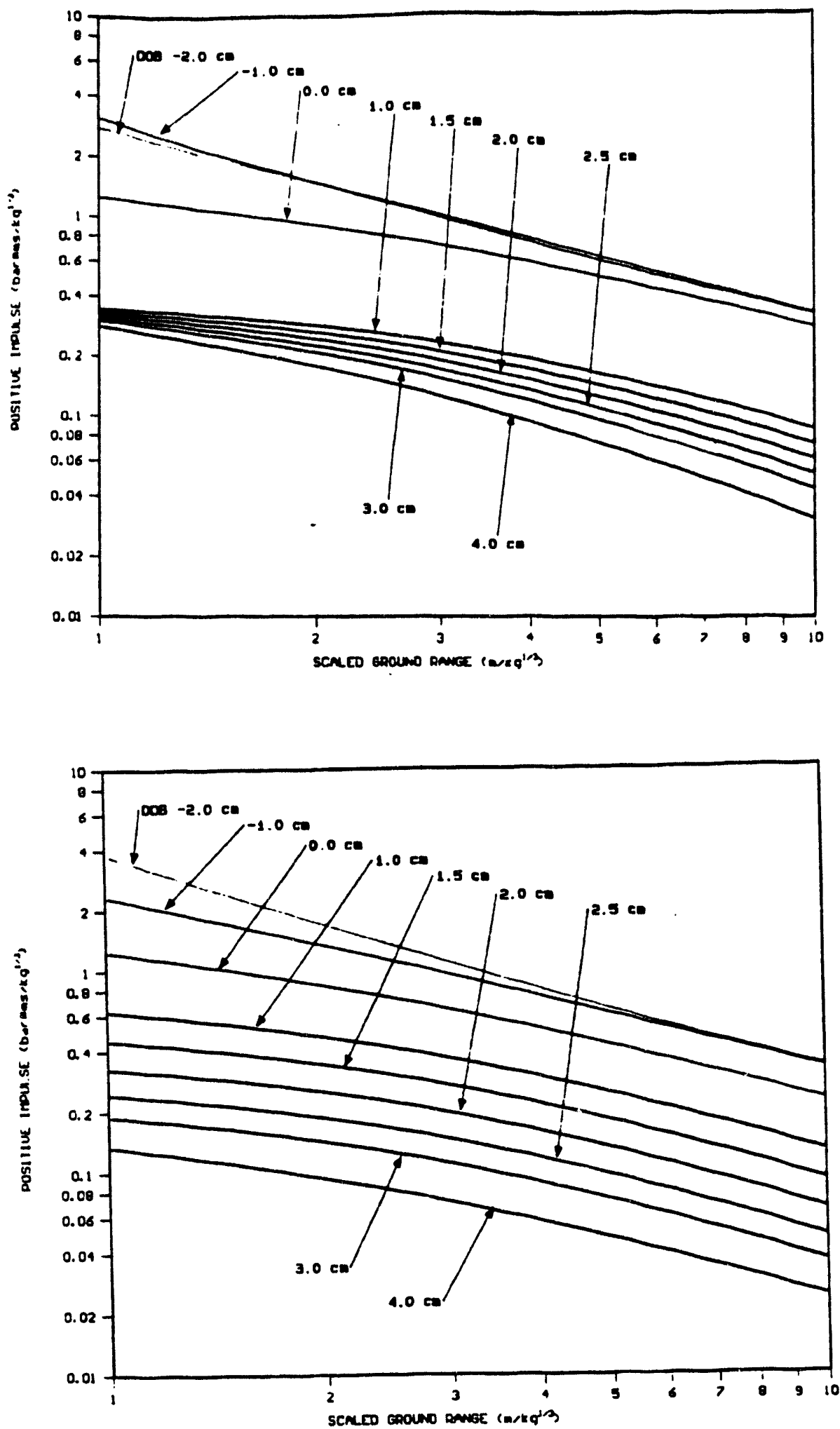

Figure 23. Overpressure-impulse vs ground-range curves for different DOB. Water-saturated grout (wet YTONG)
(a) polygon approximation
(b) polynomial approximation 

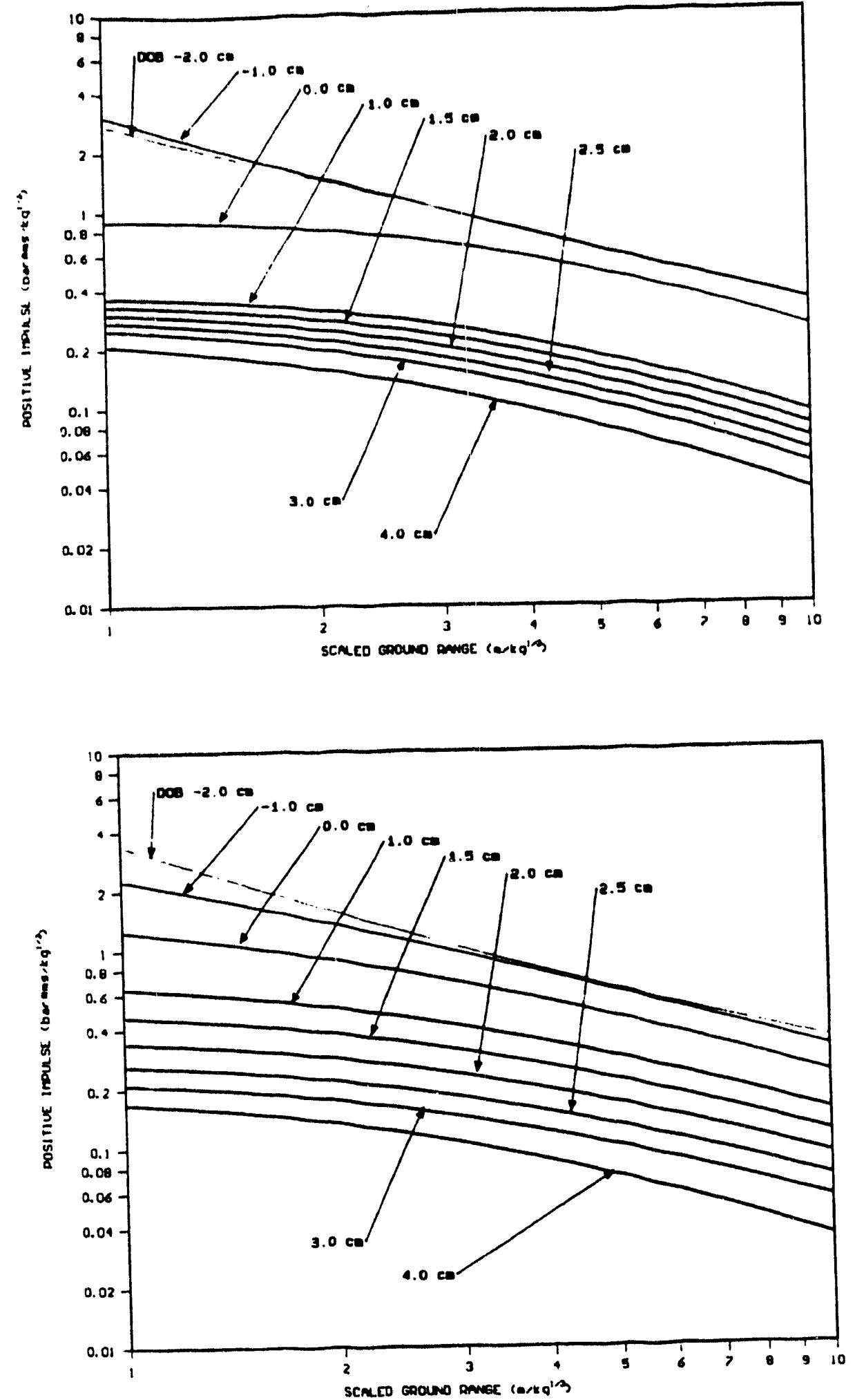

Figure 24. Overpressure-impulse vs ground-range curves for different DOB. Wet clay/loam
(a) polygon approximation
(b) polynomial approximation 


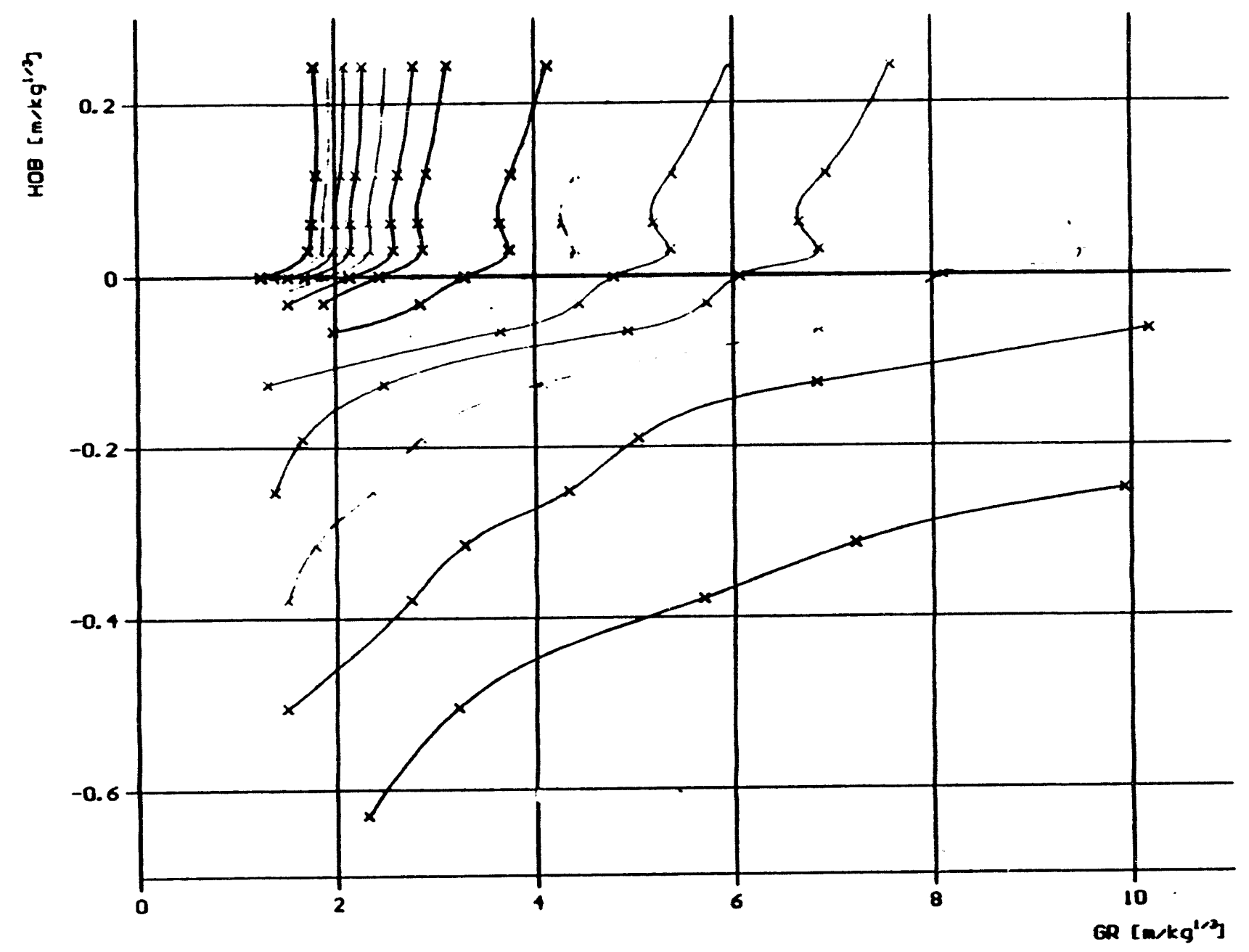

$x-x 1+=0.1$ [barmms/kg/3]

$x-x 1^{+}=0.2\left[\right.$ [barmas $\left./ \mathrm{kg}^{1 / 3}\right]$

$.+1+=0.3\left[\right.$ bar $\left.1 \mathrm{~ms} / \mathrm{kg}^{1 / 3}\right]$

$x-a I+=0.4$ [barmas $\left./ \mathrm{kg}^{1 / 3}\right]$

$A-x I+=0.5$ [barmms/kg/3]

$A-x I+=0.6$ [barmins/kg $1 / 3$

$x-x 1+=0.7$ [barmas/kgis]

$I+=0.8$ [barmos/kg1/3]

$x-x I+=0.9\left[b a r m s / k^{2 / 3}\right]$

$x-x\left[+=1\right.$ [barmas $\left./ \mathrm{kg}^{1 / 3}\right]$

$\ldots, 1+=1.1$ [barmas $/ k^{1 / 3}$ ]

A... $\left[t=1.2\right.$ [barmas $/ \mathrm{kg}^{1 / 3}$ ]

$x-x I+=1.3$ cbarmos/kgi3

$x-x I+=1.4$ cbarmos $/ \mathrm{kg}^{1 / 3}$

$x-X I+=1.5$ cbarms $/ k g 13$ ]

Figure 25a. Iso-impulse DOB curves for dry aerated grout (dry YTONG).

Spline function approximation 


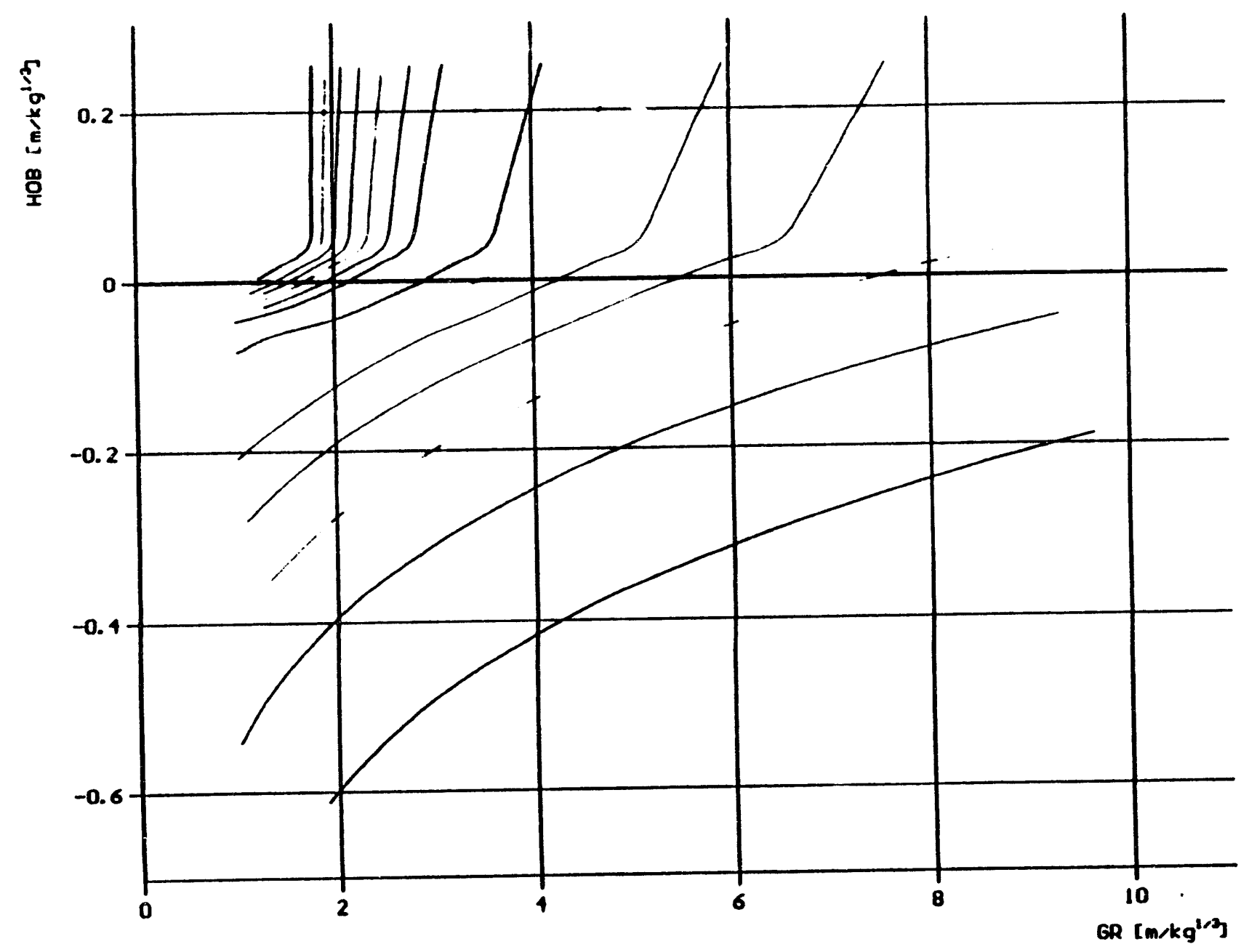

$-1+=0.1$ [bar mns $/ \mathrm{kg}^{1 / 3}$ ]

$-1+=0.2$ cbarmns $/ k^{1 / 2}$

$1+=0.3$ cbarmms $/ k^{1 / 3}$

$\ldots$ It $=0.4$ [barmms/kg [b] $^{1 / 3}$

- $I+=0.5$ [barmms/kq/3]

it $=0.6$ [bar mas/kgl/3]

$-1+=0.7$ [barmins/kg ${ }^{1 / 3}$

$1+=0.8$ [barmms $/ \mathrm{kg}^{1 / 2}$ ]

$-1+=0.9$ [barmms/kg/3]

- It $=1$ [bar ms $/ \mathrm{kg}^{1 / 3}$ ]

$-I+=1.1$ [barmins/kgin]

- It $=1.2\left[\right.$ bar wns $\left./ \mathrm{kg}^{1 / 3}\right]$

$-1+=1.3$ [bar mons $/ \mathrm{kg}^{1 / 3}$

- $1+=1.4$ [bar mos $/ k g / 3$

$I+=1.5$ [barmos $/ \mathrm{kg}^{1 / 3}$

Figure 25b. Iso-impulse DOB curves for dry aerated grout (dry YTONG).

Polygon approximation 


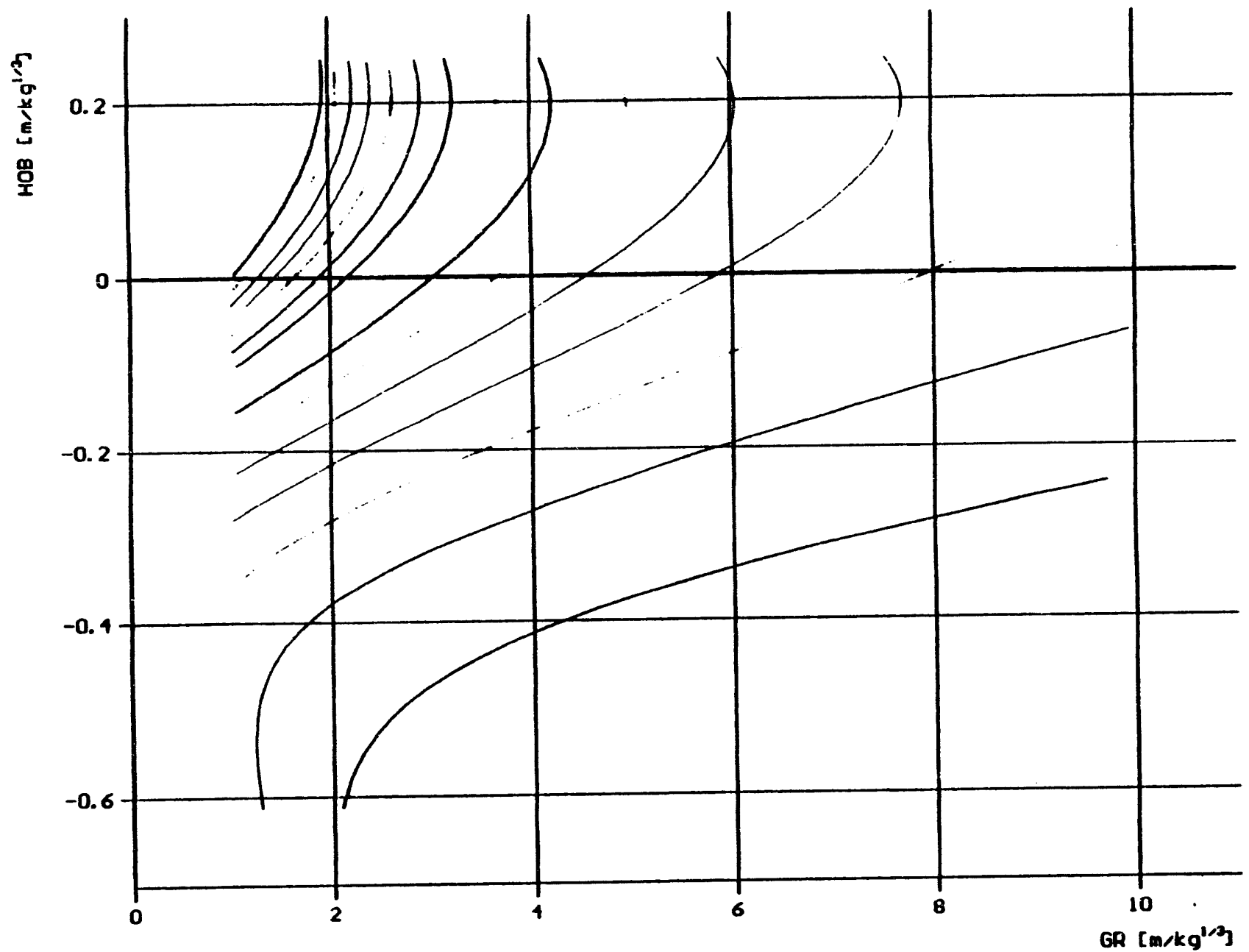

$-1+=0.1$ [barmms $\left./ \mathrm{kg}^{1 / 3}\right]$

- it $=0.2[$ barmins/kgl/3]

$1+=0.3\left[\right.$ bar mms $\left./ \mathrm{kg}^{1 / 3}\right]$

- $1+=0.4$ [barmms/kg/3]

L It $=0.5$ [barms $/ \mathrm{kg}^{1 / 3}$ ]

..... It $=0.6\left[\right.$ barmms $\left./ \mathrm{kg}^{1 / 3}\right]$

- It $=0.7$ [barmms/kg/3)

$I+=0.8\left[\right.$ barmms $\left./ \mathrm{kg}^{1 / 3}\right]$

$-1+=0.9$ (bar $\left.m_{m s} / k^{1 / 3}\right)$

$I+=1[$ barmns/kg $/ 13$ ]

$I+=1.1$ [barmos $/ \mathrm{kg}^{1 / 3}$

- It $=1.2$ [bar wms/kgl乃]

$-1+=1.3$ [barmms/kg/3]

$\ldots \ldots-1+=1.4$ [barwns/kq/3]

$-I+=1.5\left[\right.$ barms $\left.{ }^{\prime} / \mathrm{kg}^{1 / 3}\right]$

Figure 25c. Iso-impulse DOB curves for dry aerated grout (dry YTONG).

Polynomial approximation 

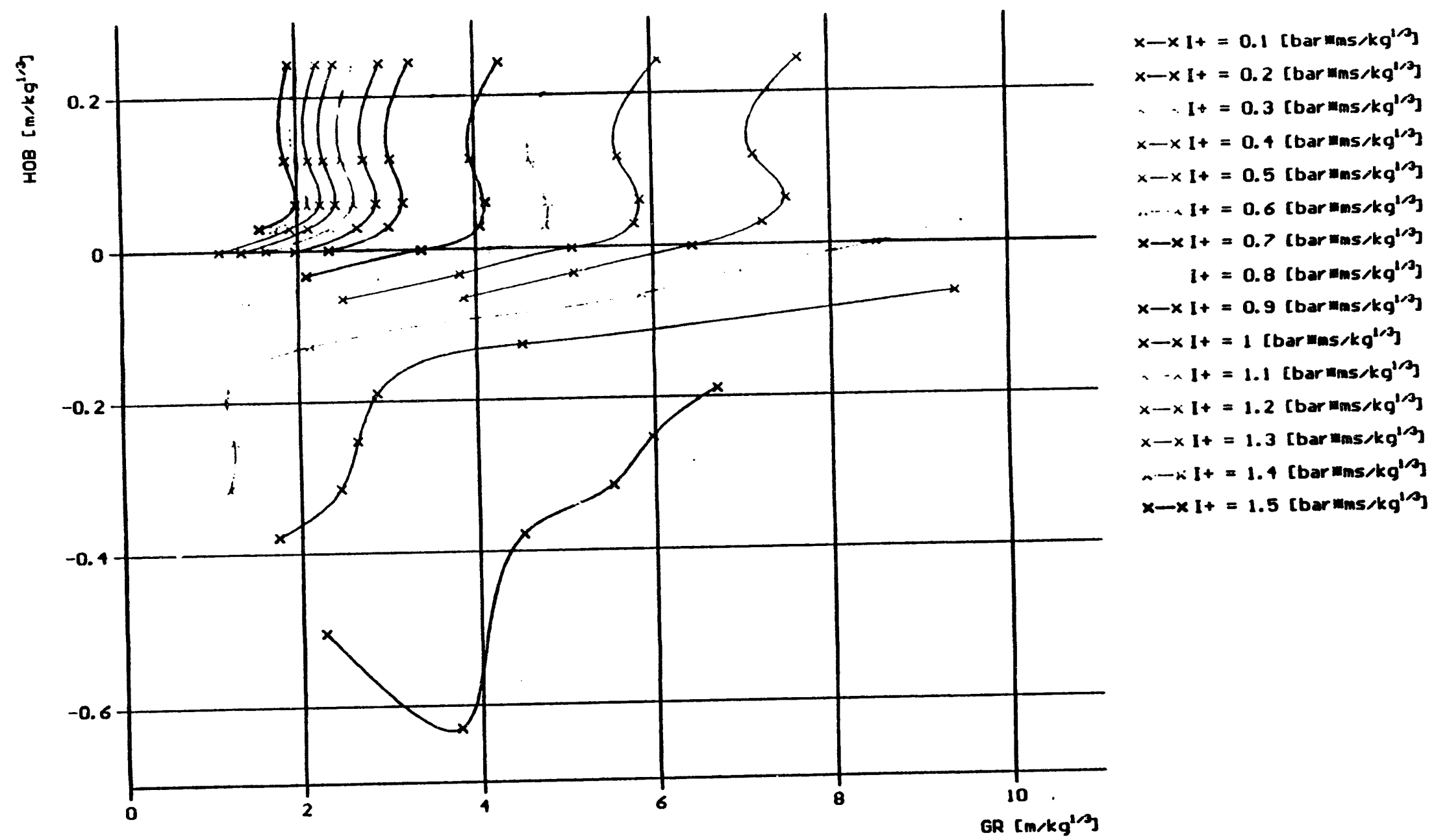

Figure 26a. Iso-impulse DOB curves for water-saturated grout (wet YTONG) Spline function approximation 


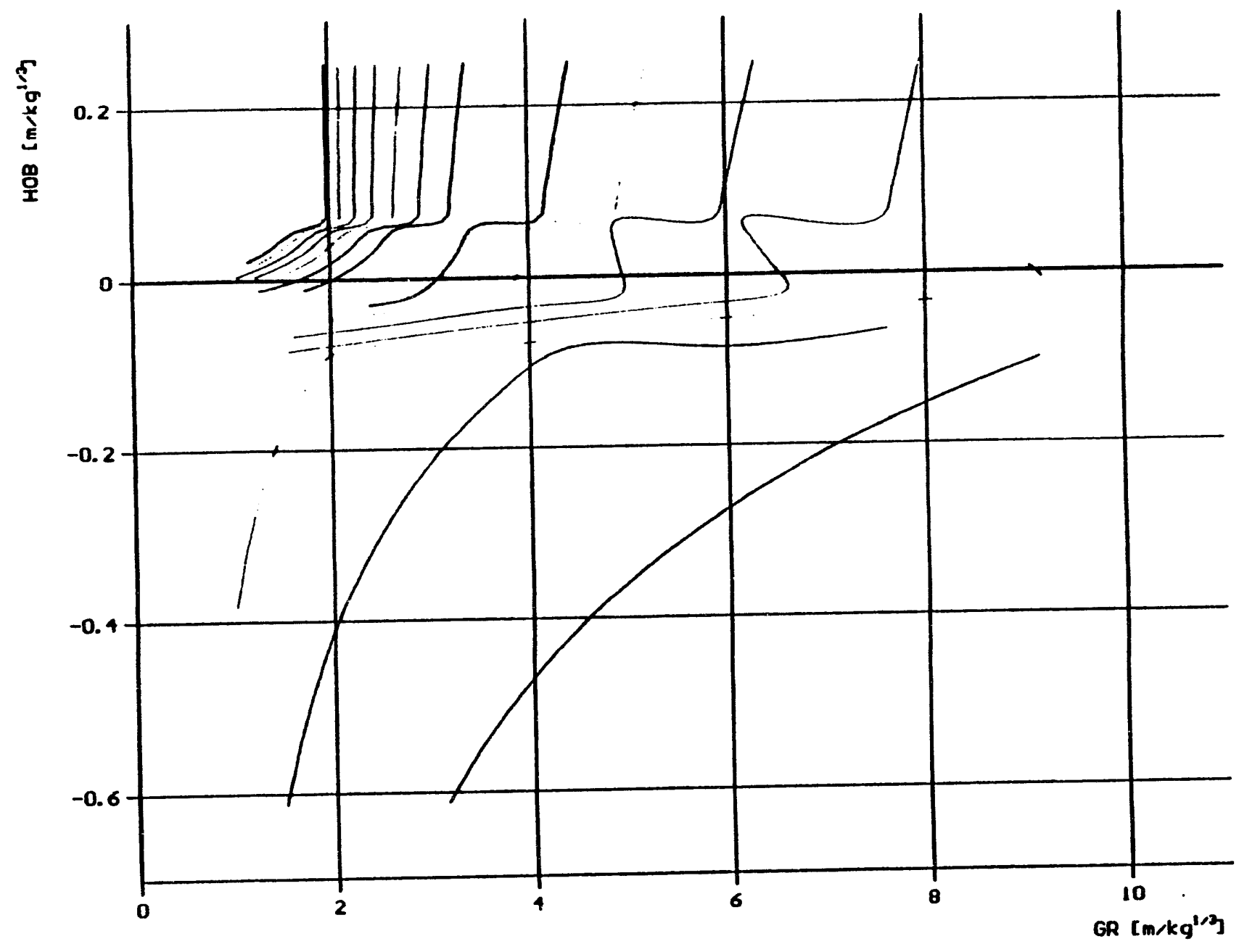

$-1+=0.1[$ bar mms/kg/3]

$-I+=0.2$ [bar $m s / k g / 3]$

$\mathrm{It}=0.3$ [Darmms/kg)/3]

$-I+=0.4$ [barmins/kg/3

$\ldots+1+=0.5\left[\right.$ barmms $/ \mathrm{kg}^{1 / 3}$

$-\ldots 1+=0.6$ [barmns/kg1/3

$-I+=0.7$ [barmms $/ \mathrm{kg}^{1 / 3}$

It $=0.8\left[\mathrm{bar} m \mathrm{~ms} / \mathrm{kg}^{1 / 3}\right]$

$-I^{+}=0.9$ [bar mms $\left./ \mathrm{kg}^{\mathrm{i}} \mathrm{]}\right]$

- It $=1$ [barmns/kg $1 / 3]$

.. It $=1.1$ [barmms/kg $1 / 3$

$\ldots \ldots I+=1.2$ [bar $\mathrm{mss}_{\mathrm{m}} \mathrm{kg} \mathrm{g}^{1 / 3}$ ]

$-1+=1.3$ [bar mms $\left./ \mathrm{kg}^{1 / 3}\right]$

$\ldots \ldots$.... It $=1.4$ [barmns/kg $1 / 3$

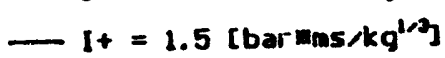

Figure 26b. Iso-impulse DOB curves for water-saturated grout (wet YTONG) Polygon approximation 


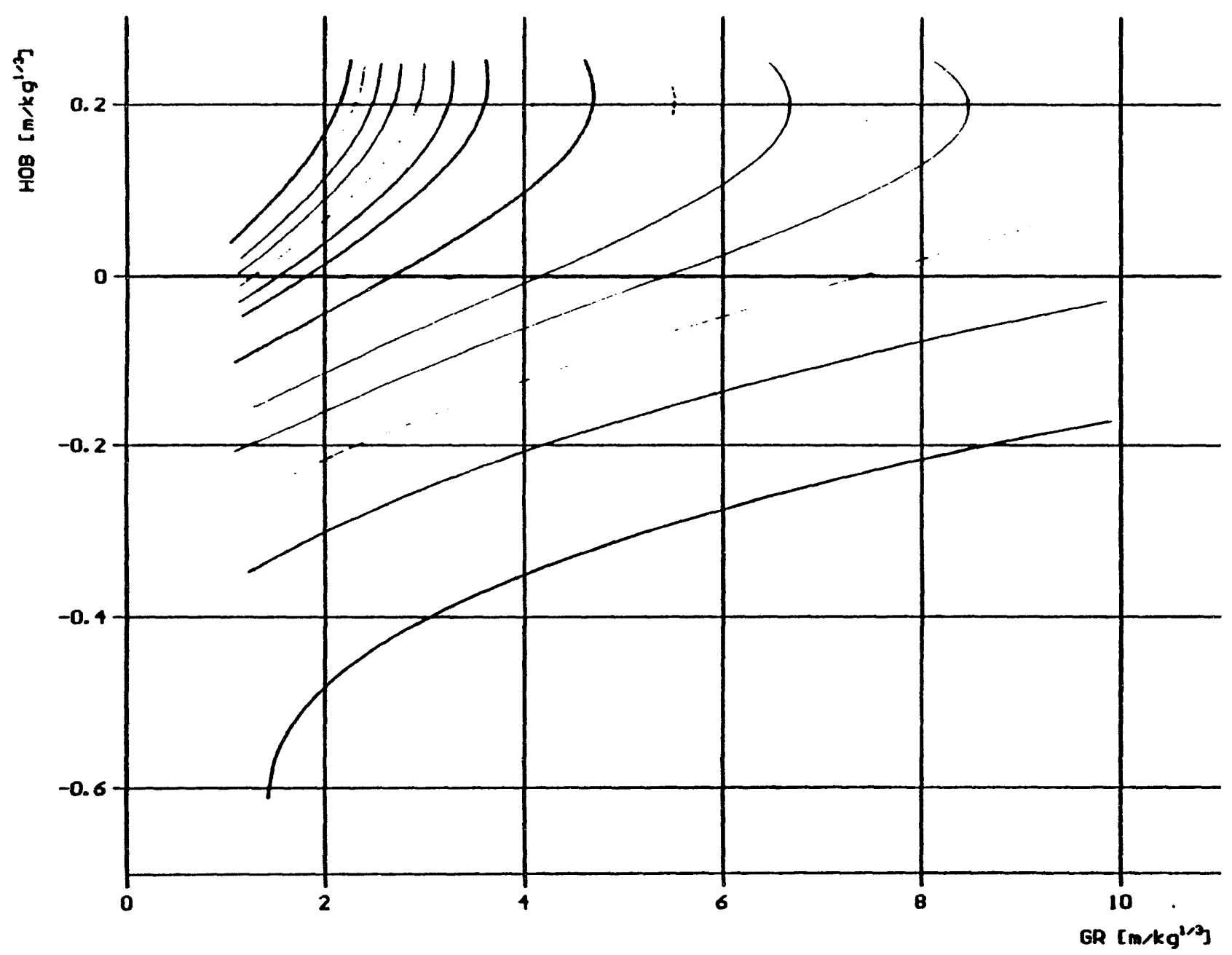

- It = 0.1 [bar $\left.\mathrm{ms} / \mathrm{kg}^{\mathrm{i} / 3}\right]$

- It $=0.2\left[\mathrm{bar} m \mathrm{~ms} / \mathrm{kg}^{1 / 3}\right]$

$I t=0.3$ [barmms $\left./ \mathrm{kg}^{1 / 3}\right]$

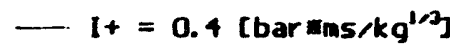

- I+ $=0.5$ [barms $/ \mathrm{kg}^{1 / 3}$ ]

$\mathrm{It}=0.6$ [barmms/kg/3]

- It $=0.7$ [barmms $\left./ \mathrm{kg}^{1 / 3}\right]$

$I+=0.8\left[\right.$ bar $\left.m s / \mathrm{mg}^{1 / 3}\right]$

- It $=0.9$ [barmns $\left./ \mathrm{kg}^{1 / 3}\right]$

- $1+=1$ [barms $/ \mathrm{kg}^{1 / 3}$ ]

… It $=1.1$ cbarmms/kg/3]

- It = $1.2\left[\mathrm{bar} m \mathrm{~ms} / \mathrm{kg}^{1 / 3}\right]$

- It $=1.3$ [bar $\left.\mathrm{ms}_{\mathrm{m}} / \mathrm{kg}^{1 / 3}\right]$

It $=1.4$ [bar mans/kg/3]

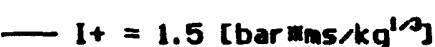

Figure 26c. Iso-impulse DOB curves for water-saturated grout (wet YTONG) Polynomial approximation 

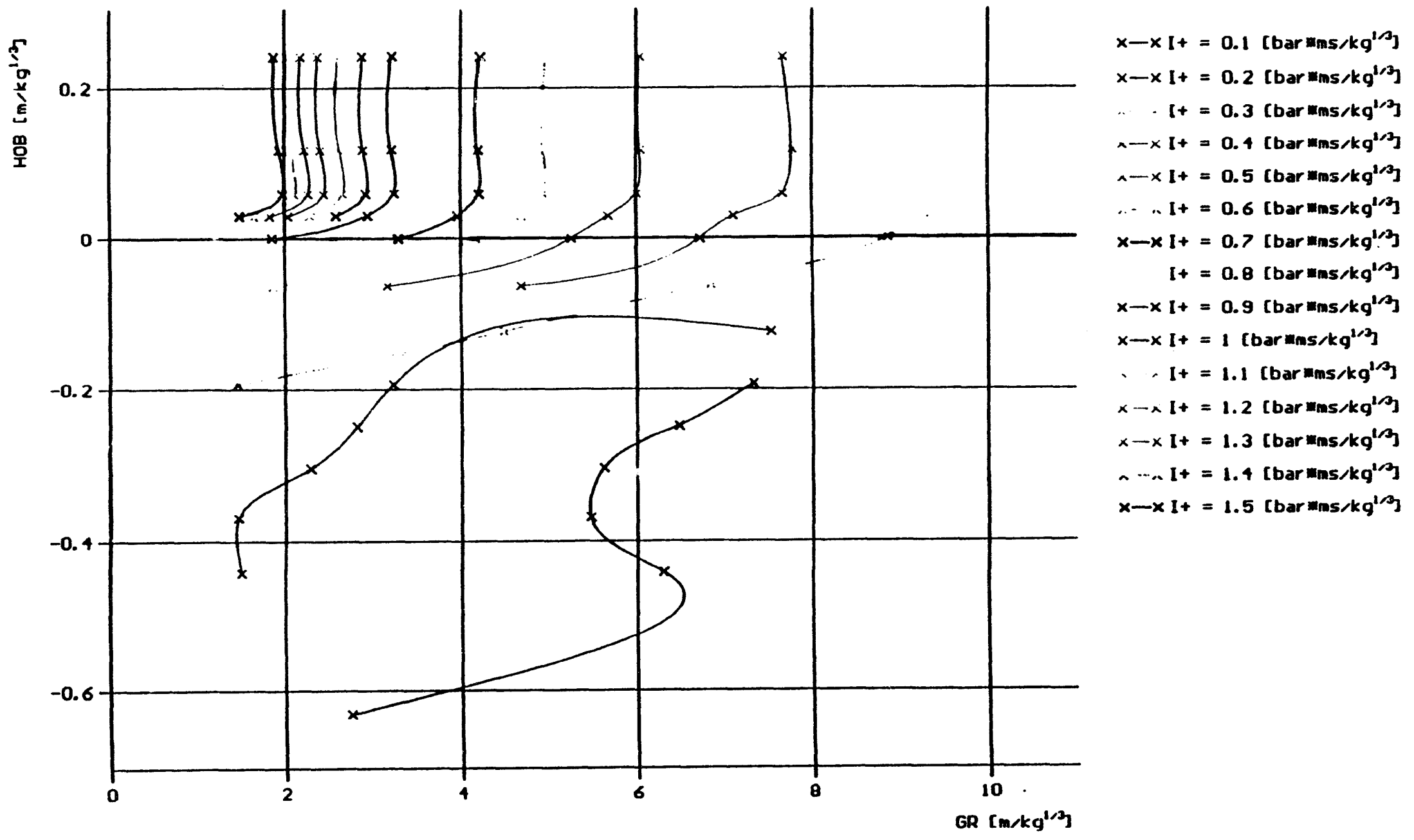

Figure 27a. Iso-impulse DOB curves for wet clay/loam.

Spline function approximation 


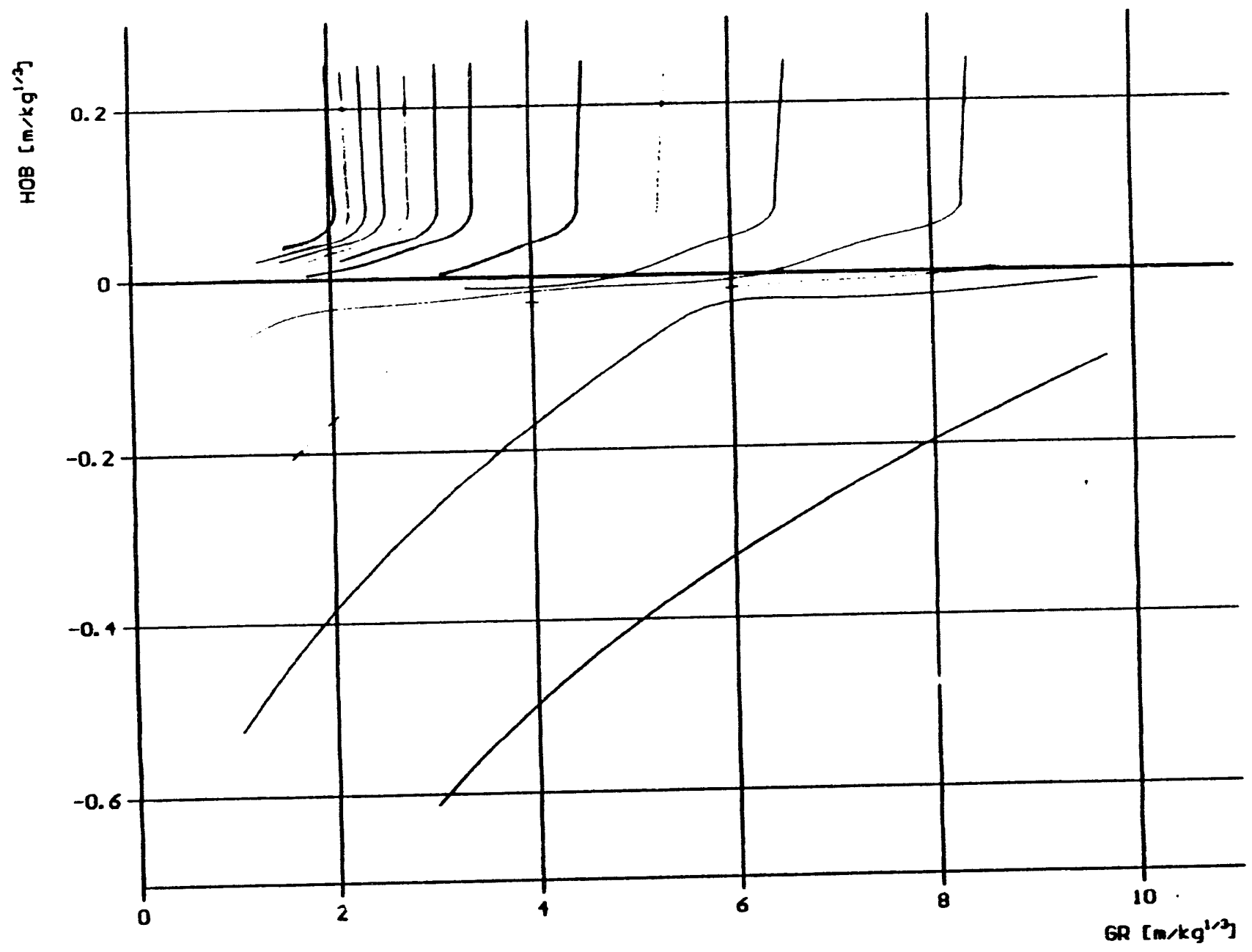

$-I+=0.1$ [barmms/kg/3]

$-\mathrm{I}+=0.2\left[\mathrm{bar} \mathrm{ms}_{\mathrm{m}} / \mathrm{kg}^{\mathrm{I/3}}\right]$ $\mathrm{It}=0.3\left[\mathrm{bar} \mathrm{ms} / \mathrm{kg}^{1 / 3}\right]$

$-I^{+}=0.4\left[\mathrm{bar} m \mathrm{~ms} / \mathrm{kg}^{\mathrm{l} / 3}\right]$

$-1+=0.5\left[\right.$ bar $\left.m s / k^{2} g^{1 / 3}\right]$ It $=0.6$ [barmms/kg/3] $\mathrm{I}+\mathrm{It}=0.7$ [bar $\mathrm{ms} / \mathrm{kg}^{\mathrm{i} / 3}$ $I+=0.8[$ barmms/kg $1 / 3]$

$-1+=0.9\left[\mathrm{bar} m \mathrm{~ms} / \mathrm{kg}^{1 / 3}\right]$

$-I+=1$ [barms/ $\left./ \mathrm{kg}^{1 / 3}\right]$ $I+=1.1$ tbarms $/ \mathrm{kg}^{1 / 3}$ $-1+=1.2\left[\right.$ barms $\left.m / \mathrm{kg}^{1 / 3}\right]$ - $I+=1.3[\mathrm{bar} m \mathrm{~ms} / \mathrm{kg} / \mathrm{3}]$ $\ldots \ldots$. It $=1.4[$ [bar mos/kg $1 / 3]$

- It $=1.5\left[\right.$ bar $\mathrm{mms}_{\mathrm{m}} \mathrm{kg} / \mathrm{s}$

Figure 27b. Iso-impulse DOB curves for wet clay/loam. Polygon approximation 


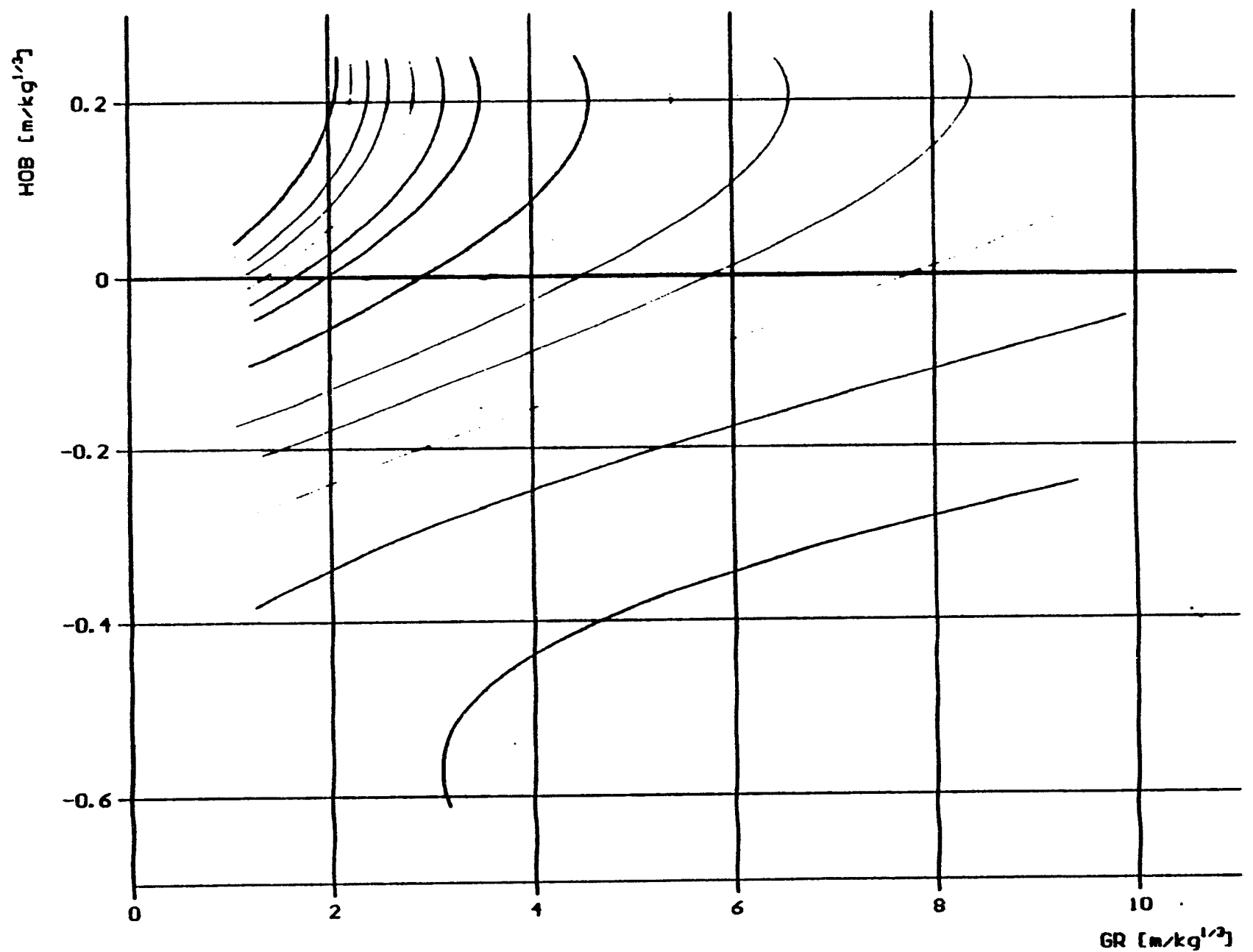

- It $=0.1[\mathrm{bar} m \mathrm{~ms} / \mathrm{kg} / \mathrm{S}]$

- It $=0.2\left[\right.$ bar $\left.\mathrm{mms}_{\mathrm{m}} / \mathrm{kg}^{1 / 3}\right]$

$\mathrm{It}=0.3\left[\mathrm{bar} \mathrm{ms} / \mathrm{kg}^{\mathrm{l} / 3}\right]$

- It $=0.4\left[\right.$ barmms/kg $\left.{ }^{1 / 3}\right]$

$-I+=0.5\left[\mathrm{bar} m \mathrm{~ms} / \mathrm{kg}^{1 / 3}\right]$

. $\ldots 1+=0.6\left[\mathrm{bar} / \mathrm{ms} / \mathrm{kg}^{1 / 3}\right]$

- $1+=0.7\left[\right.$ barmas $\left./ \mathrm{kg}^{1 / 3}\right]$ $1+=0.8\left[\right.$ barms $\left./ \mathrm{kg}^{1 / 3}\right]$

- It $=0.9\left[\mathrm{barmms} / \mathrm{kg}^{1 / 3}\right]$

- It $=1$ [barmms $\left./ \mathrm{kg}^{2 / 3}\right]$ $I_{t}=1.1$ lbar $\mathrm{mms}_{\mathrm{m}} \mathrm{kg} / \mathrm{3}$

$-I^{+}=1.2\left[\mathrm{bar} m \mathrm{~ms} / \mathrm{kg}^{1 / 3}\right]$

- It $=1.3[\mathrm{bar} m \mathrm{~ms} / \mathrm{kg} / \mathrm{B}]$

$\ldots-1+=1.4\left[\right.$ bar $\left.\mathrm{ms}^{\mathrm{m}} / \mathrm{kg}^{1 / 3}\right]$

$-1+=1.5\left[\mathrm{bar} m \mathrm{~ms} / \mathrm{kg}^{1 / 3}\right]$

Figure 27c. Iso-impulse DOB curves for wet clay/loam.

Polynomial approximation 


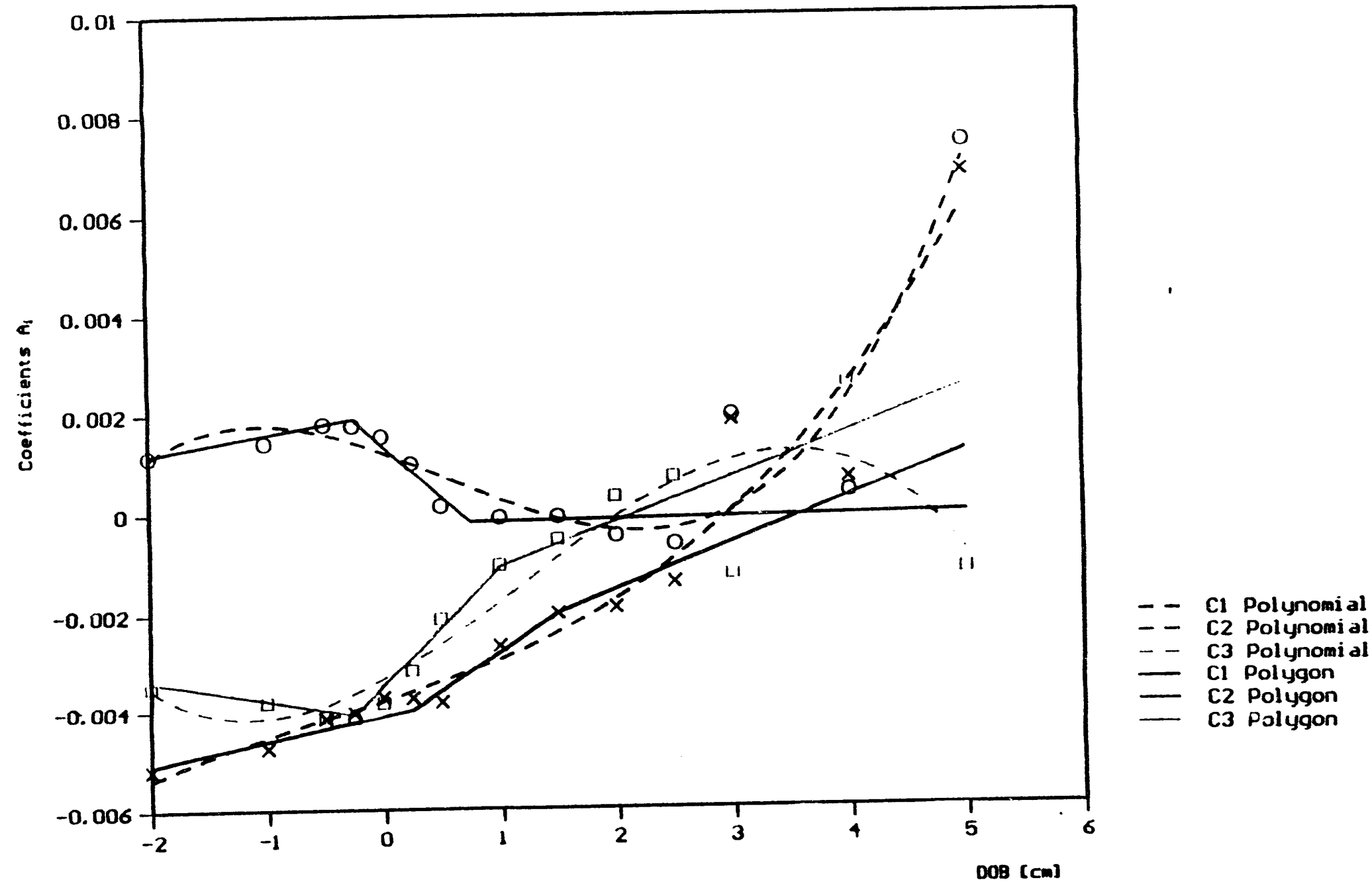

Figure 28. Coefficients of approximation functions for arrival time vs ground range at different DOB.

Aerated grout (dry YTONG); polynomial and polygon approximation 


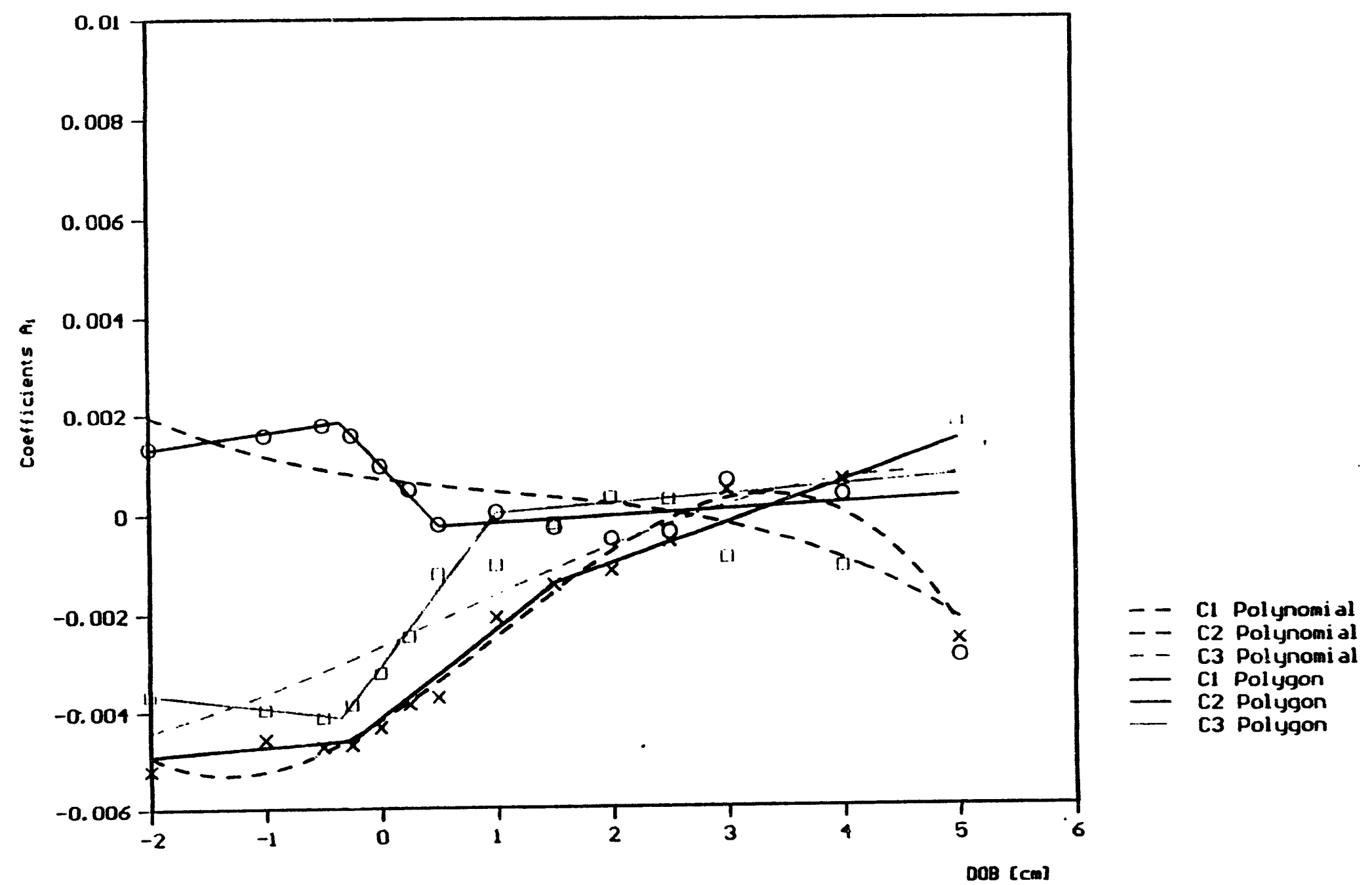

Figure 29. Coefficients of approximation functions for arrival time vs ground range at different DOB.

Water-saturated grout (wet YTONG); polynomial and polygon approximation 


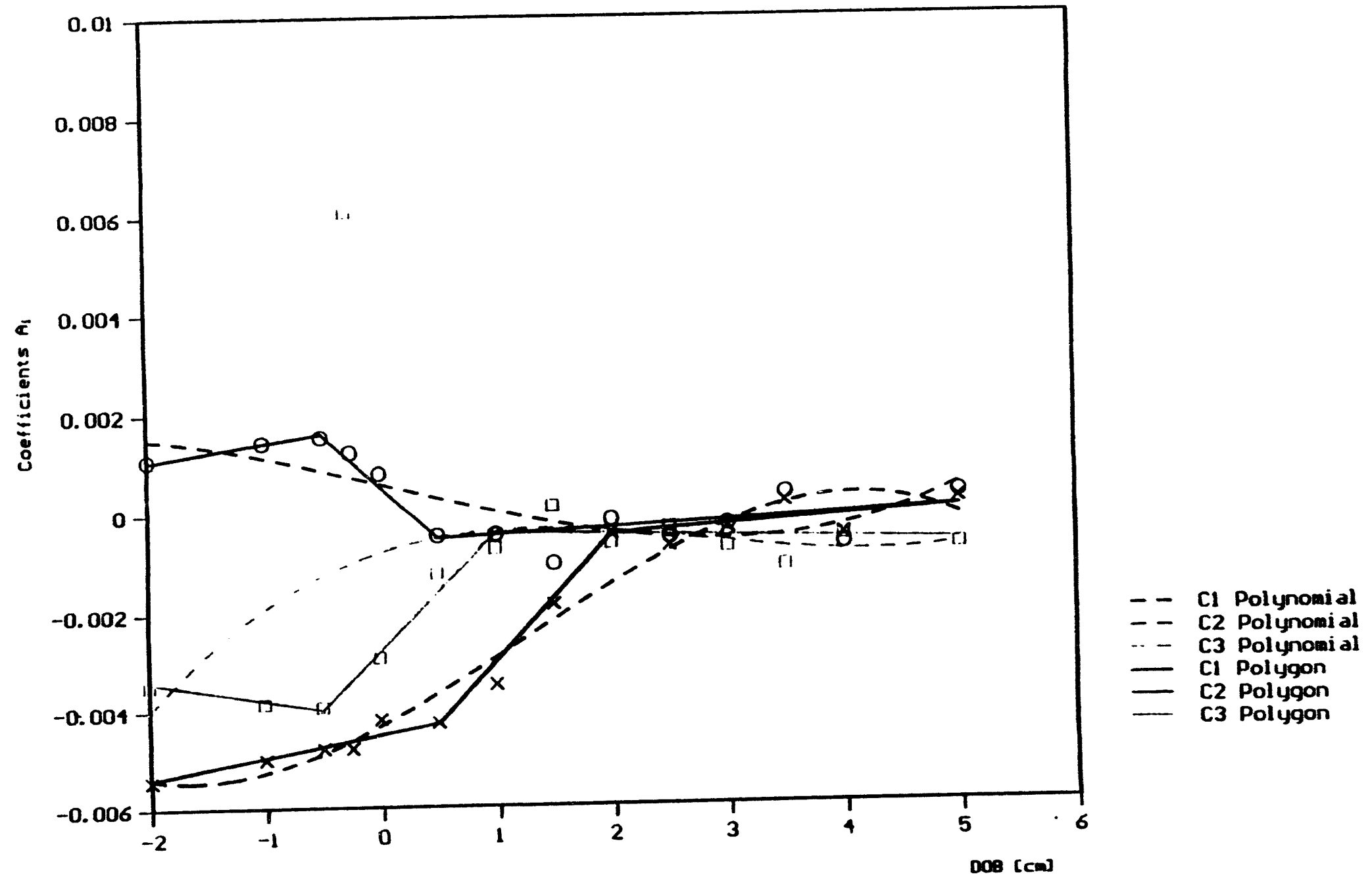

Figure 30. Coefficients of approximation functions for arrival time vs ground range at different DOB.

Wet clay/loam; polynomial and polygon approximation 

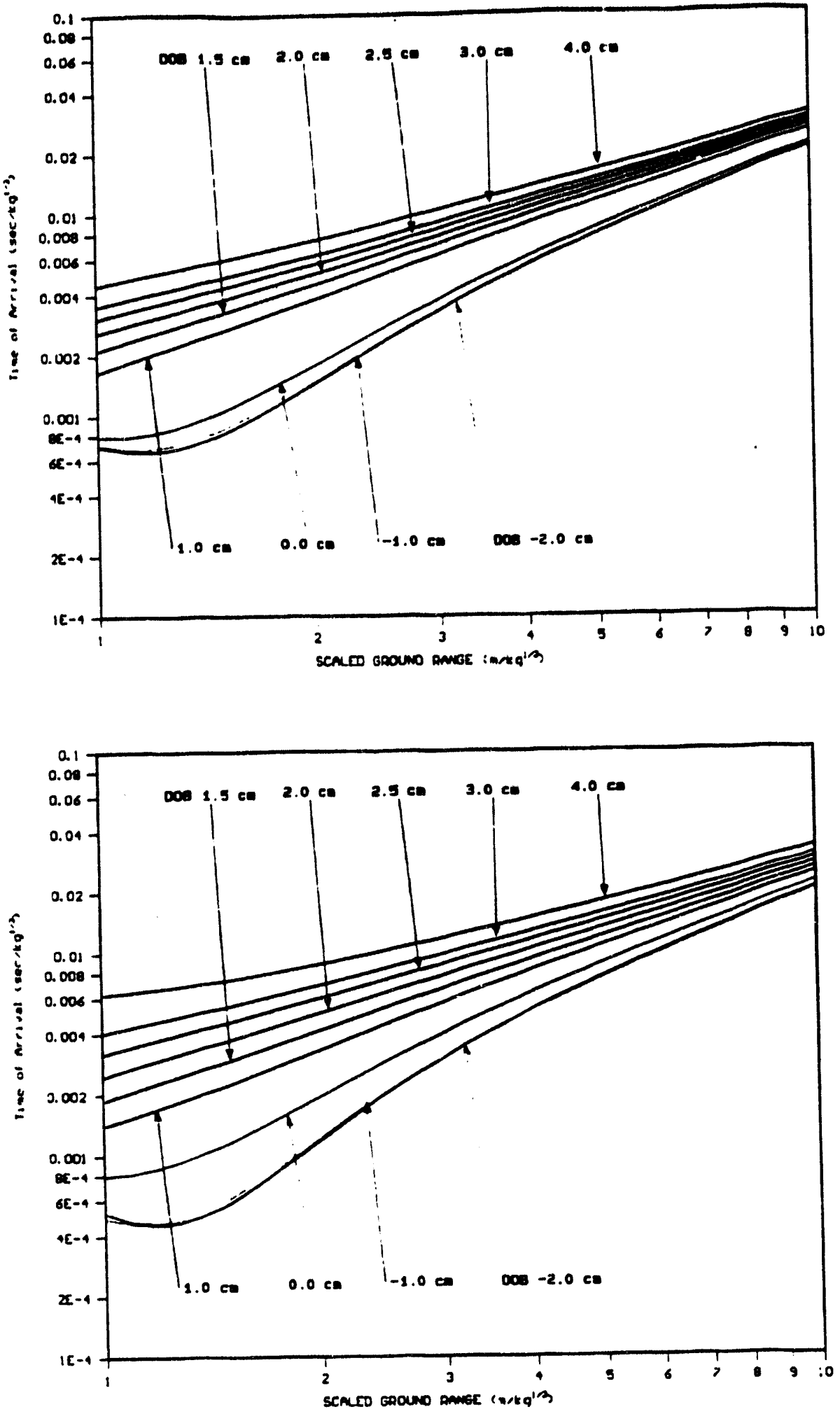

Figure 31. Arrival-time vs ground-range curves for different DOB. Aerated grout (dry YTONG)
(a) polygon approximation
(b) polynomial approximation 

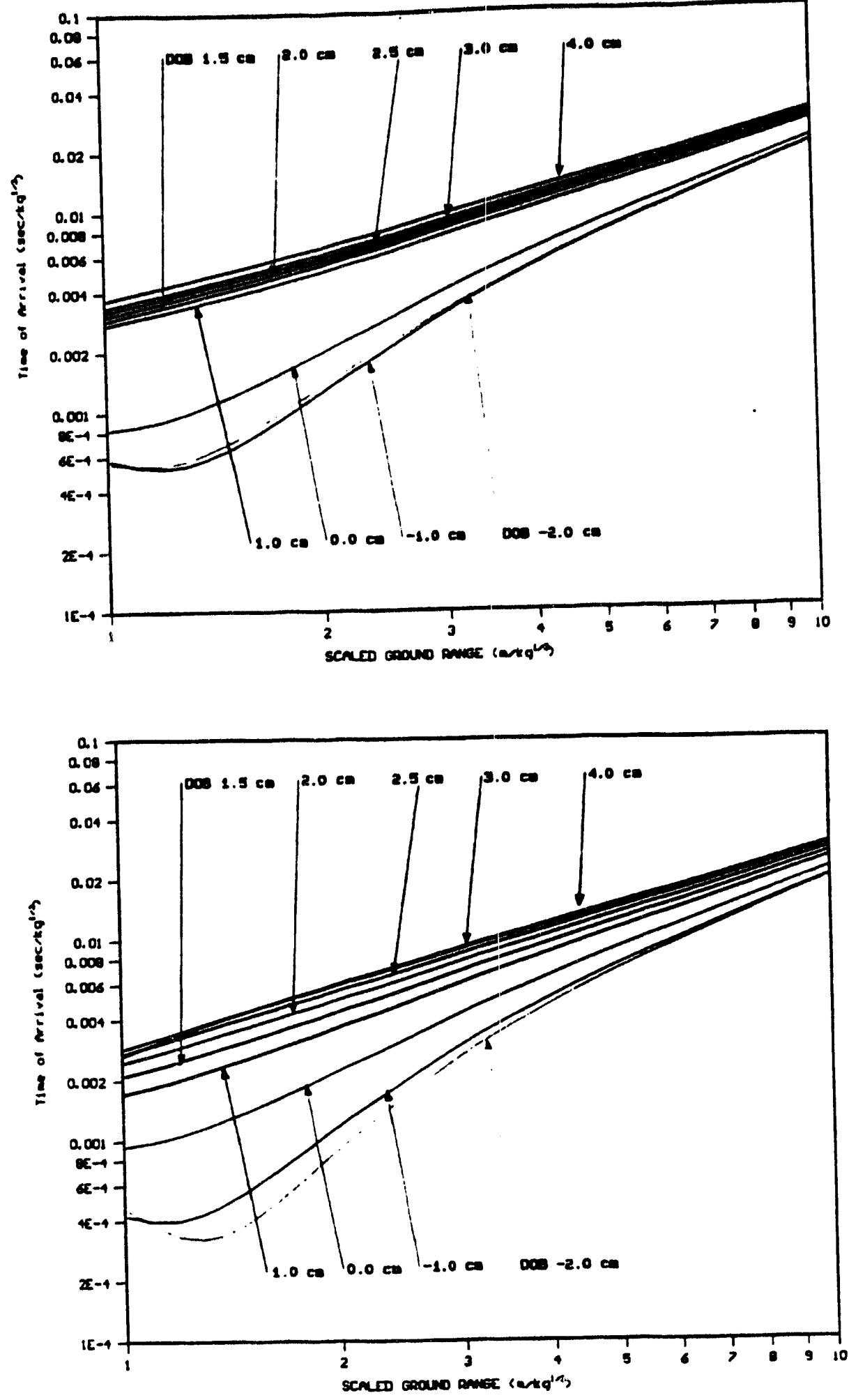

Figure 32. Arrival-time vs ground-range curves for different DOB. Water-saturated grout (wet YTONG)

$\begin{array}{ll}\text { (a) polygon approximation (b) polynomial approximation } & \end{array}$ 

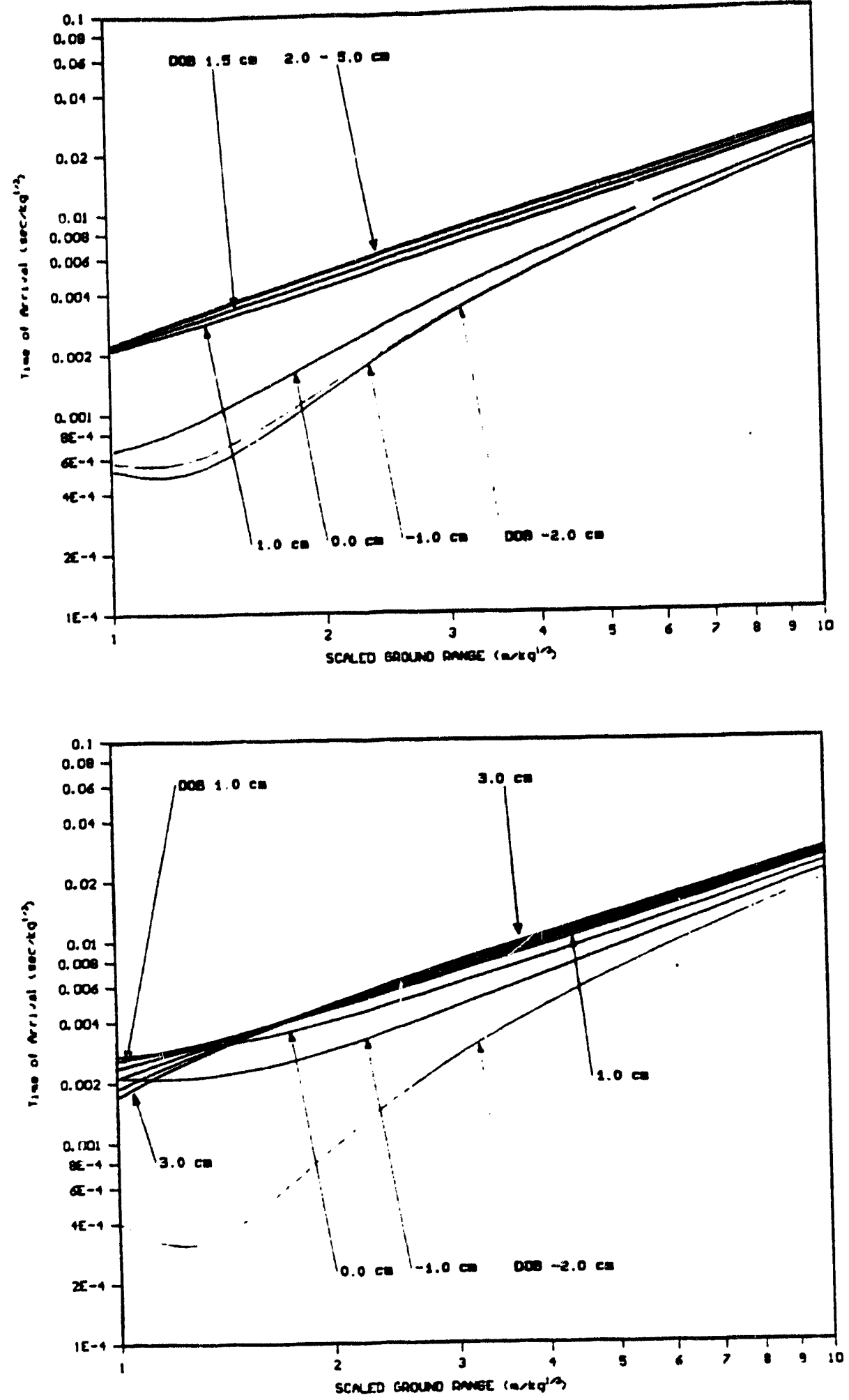

Figure 33. Arrival-time vs ground-range curves for different DOB. Wet clay/loam
(a) polygon approximation
(b) polynomial approximation 


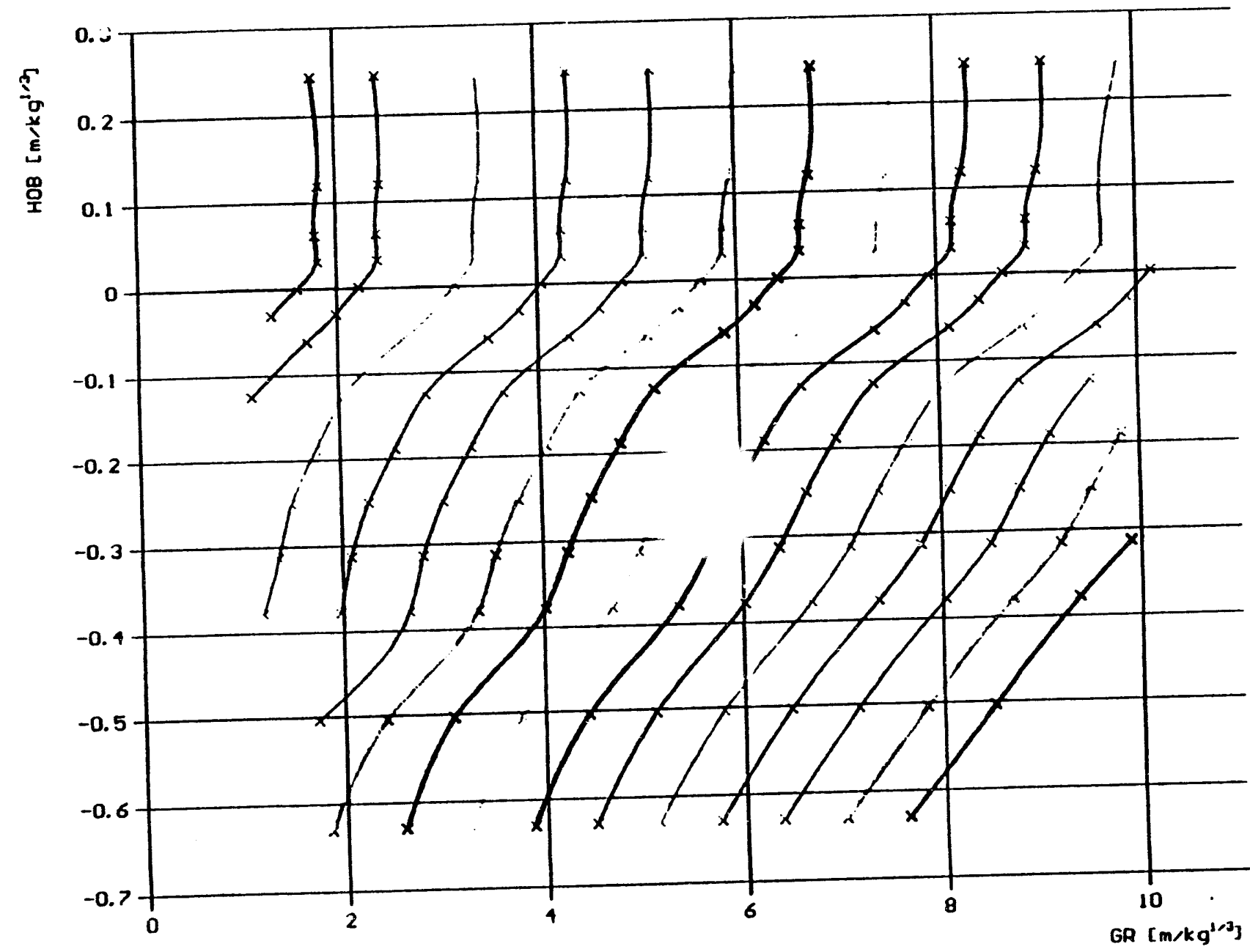

$x-x$ TA $=0.001\left[\mathrm{sec} / \mathrm{kg}^{1 / 3}\right]$ $x-x$ TA $=0.002\left[\mathrm{sec} / \mathrm{kg}^{1 / 3}\right]$ -.. $T_{A}=0.004\left[\mathrm{sec} / \mathrm{kg}^{1 / 3}\right]$ . $\times$ TA $=0.006\left[\mathrm{sec} / \mathrm{kg}^{1 / 3}\right]$ $A$ - TA $=0.008\left[\sec / \mathrm{kg}^{1 / 3}\right]$ $n-x$ TA $=0.01\left[\sec / \mathrm{kg}^{1 / 3}\right]$ $X-X T_{A}=0.012\left[\mathrm{sec} / \mathrm{kg}^{1 / 3}\right]$ $T_{A}=0.014\left[\sec / \mathrm{kg}^{1 / 3}\right]$ $x-x$ TA $=0.016\left[\mathrm{sec} / \mathrm{kg}^{1 / 3}\right]$ $X-X$ TA $=0.018\left[\mathrm{sec} / \mathrm{kg}^{1 / 3}\right]$ $\ldots . T_{A}=0.02\left[\mathrm{sec} / \mathrm{kg}^{1 / 3}\right]$ $\wedge$ ATA $=0.022\left[\sec / \mathrm{kg}^{1 / 3}\right]$ A $A$ TA $=0.024\left[\mathrm{sec} / \mathrm{kg}^{1 / 3}\right]$ $x$ X X TA $=0.026\left[\sec / \mathrm{kg}^{1 / 3}\right]$ $x-x$ TA $=0.028\left[\sec / \mathrm{kg}^{1 / 3}\right]$

Figure 34a. Constant arrival time DOB curves for dry aerated grout (dry YTONG) Spline function approximation 


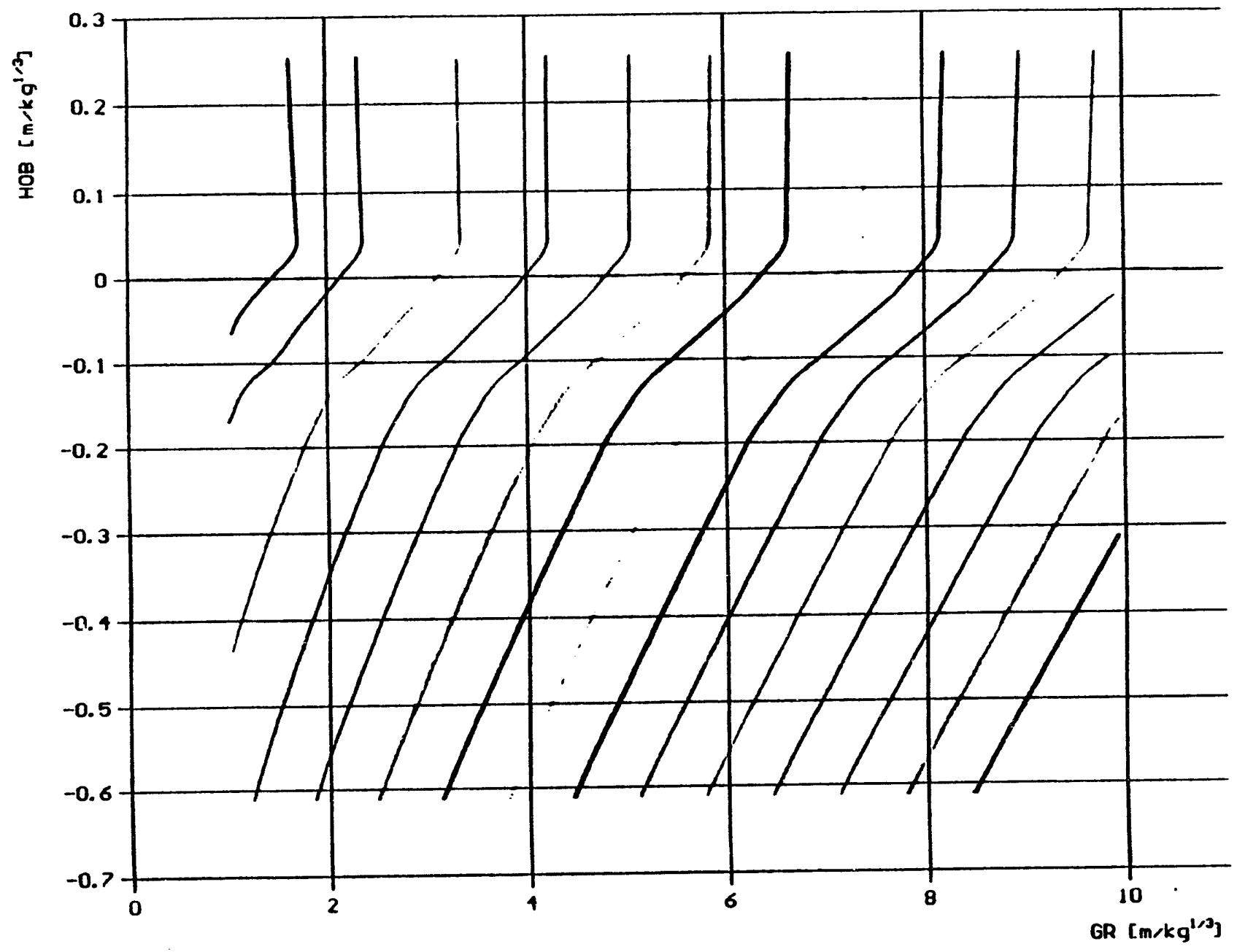

$-T_{A}=0.001\left[\mathrm{sec} / \mathrm{kg}^{1 / 3}\right]$

- $T_{A}=0.002\left[\sec / \mathrm{kg}^{1 / 3}\right]$

…. IA $=0.004\left[\sec / \mathrm{kg}^{1 / 3}\right]$

- $\mathrm{TA}_{A}=0.006\left[\mathrm{sec} / \mathrm{kg}^{1 / 3}\right]$

- TA $=0.008\left[\mathrm{sec} / \mathrm{kg}^{1 / 3}\right]$

W. TA $=0.01\left[\sec / \mathrm{kg}^{1 / 3}\right]$

$-T_{A}=0.012\left[\sec / \mathrm{kg}^{1 / 3}\right]$

, $T_{A}=0.014\left[\mathrm{sec} / \mathrm{kg}^{1 / 3}\right]$

- TA $=0.016\left[\mathrm{sec} / \mathrm{kg}^{1 / 3}\right]$

- TA $=0.01 P\left[\sec / \mathrm{kg}^{1 / 3}\right]$

- $T A=0.02\left[\mathrm{sec} / \mathrm{kg}^{1 / 3}\right]$

- $\mathrm{TA}_{\mathrm{A}}=0.022\left[\mathrm{sec} / \mathrm{kg}^{1 / 3}\right]$

- $\mathrm{TA}=0.024\left[\mathrm{sec} / \mathrm{kg}^{2 / 3}\right]$

- TA $=0.026\left[\sec / \mathrm{kg}^{1 / 3}\right]$

- $\mathrm{TA}_{A}=0.028\left[\mathrm{sec} / \mathrm{kg}^{1 / 3}\right]$

Figure 34b. Constant arrival time DOB curves for dry aerated grout (dry YTONG) Polygon approximation 


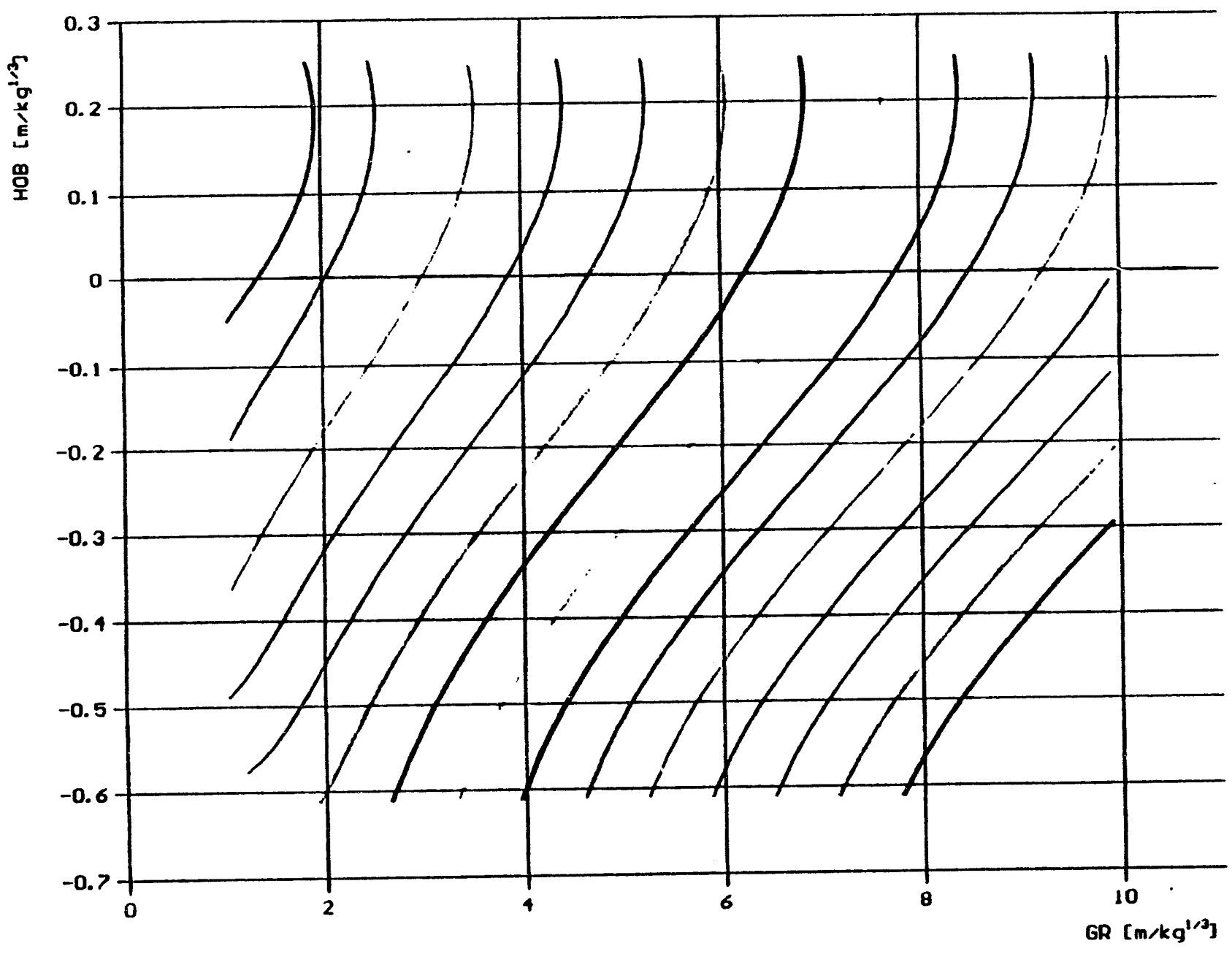

- TA $=0.001\left[\sec / \mathrm{kg}^{1 / 3}\right]$ $-T_{A}=0.002\left[\mathrm{sec} / \mathrm{kg}^{1 / 3}\right]$

- TA $=0.004\left[\sec / \mathrm{kg}^{1 / 3}\right]$

- IA $=0.006\left[\sec / k^{1 / 3}\right]$

- IA $=0.008\left[\sec / k^{1 / 3}\right]$

$\ldots$ TA $=0.01\left[\sec / \mathrm{kg}^{1 / 3}\right]$

- $T A=0.012\left[\sec / \mathrm{kg}^{1 / 3}\right]$ $T A=0.014\left[\mathrm{sec} / \mathrm{kg}^{1 / 2}\right]$

$-T_{A}=0.016\left[\sec / k^{1 / 3}\right]$

- TA $=0.018\left[\sec / \mathrm{kg}^{1 / 2}\right]$

- $T A=0.02\left[\sec / k^{1 / 2}\right]$

$T_{A}=0.022\left[\sec / \mathrm{kg}^{1 / 3}\right]$

- TA $=0.024\left[\mathrm{sec} / \mathrm{kq}^{1 / 3}\right]$

- TA $=0.026\left[\sec / \mathrm{kg}^{1 / 3}\right]$

- TA $=0.028\left[\sec / \mathrm{kg}^{1 / 3}\right]$

Figure 34c. Constant arrival time DOB curves for dry aerated grout (dry YTONG) Polynomial approximation 


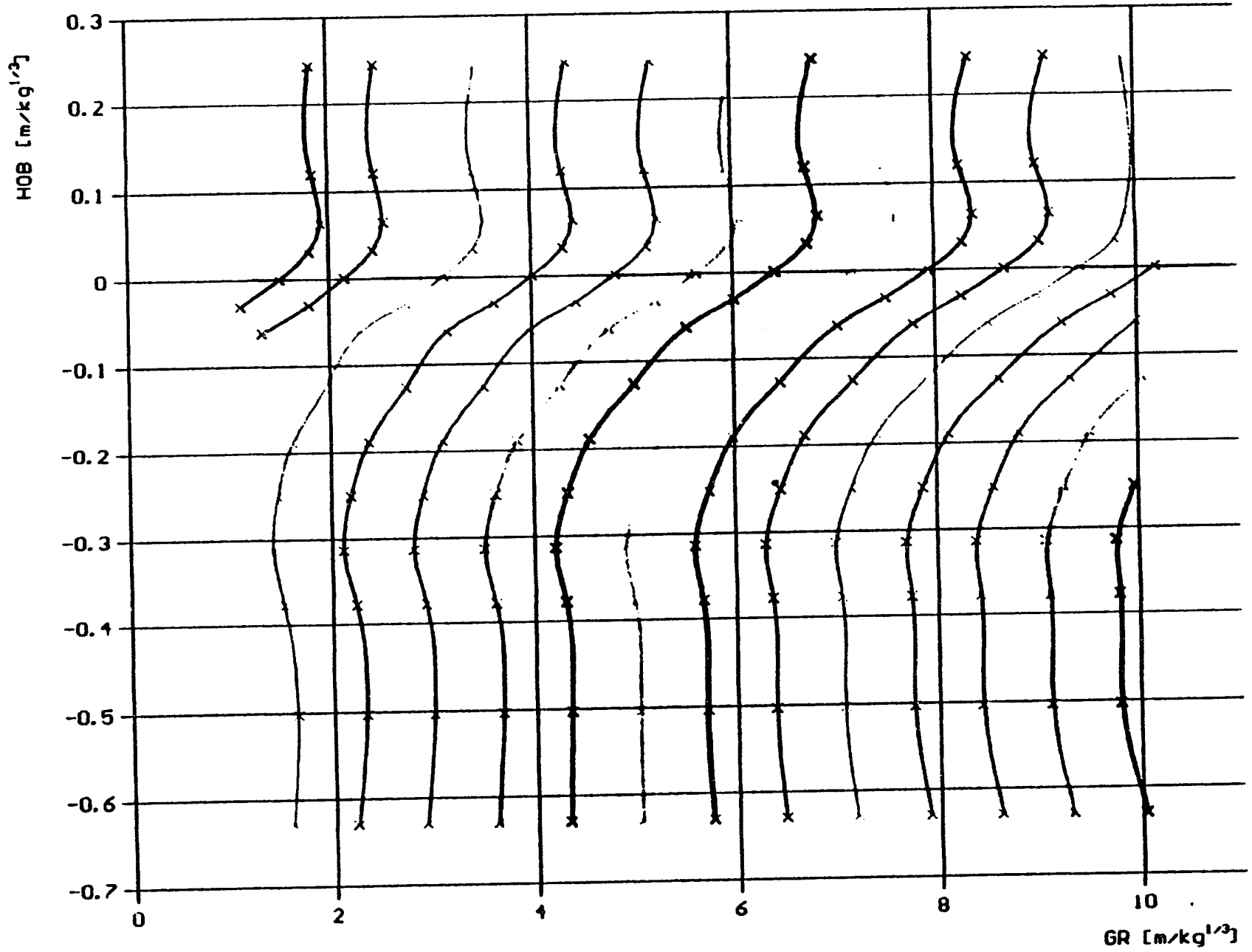

$X$ X X IA $=0.001\left[\sec / k g^{1 / 3}\right]$ $x-x$ IA $=0.002\left[\sec / \mathrm{kg}^{1 / 3}\right]$ $\ldots T_{A}=0.001\left[\sec / k g^{1 / 3}\right]$ $A-X$ IA $=0.006\left[\sec / k^{1 / 3}\right]$ $x-x$ TA $=0.008\left[\sec / \mathrm{kg}^{1 / 3}\right]$ $x \rightarrow x$ TA $=0.01\left[\sec / k g^{1 / 3}\right]$ $X-X$ TA $=0.012\left[\sec / \mathrm{kg}^{1 / 3}\right]$ $T_{A}=0.014\left[\sec / \mathrm{kg}^{1 / 3}\right]$ $X$-X IA $=0.016\left[\mathrm{sec} / \mathrm{kg}^{1 / 3}\right]$ $x-x$ IA $=0.018\left[\mathrm{sec} / \mathrm{kg}^{1 / 3}\right]$ $\cdots$ IA $=0.02\left[\sec / \mathrm{kg}^{1 / 3}\right]$ $x-x$ TA $=0.022\left[\sec / \mathrm{kg}^{1 / 3}\right]$ $\wedge$ A IA $=0.024\left[\sec / k g^{1 / 3}\right]$ A..A TA $=0.026\left[\mathrm{sec} / \mathrm{kg}^{1 / 3}\right]$ $X-X$ TA $=0.028\left[\sec / \mathrm{kg}^{1 / 3}\right]$

Figure 35a. Constant arrival time DOB curves for water-saturated grout (wet YTONG) Spline function approximation 


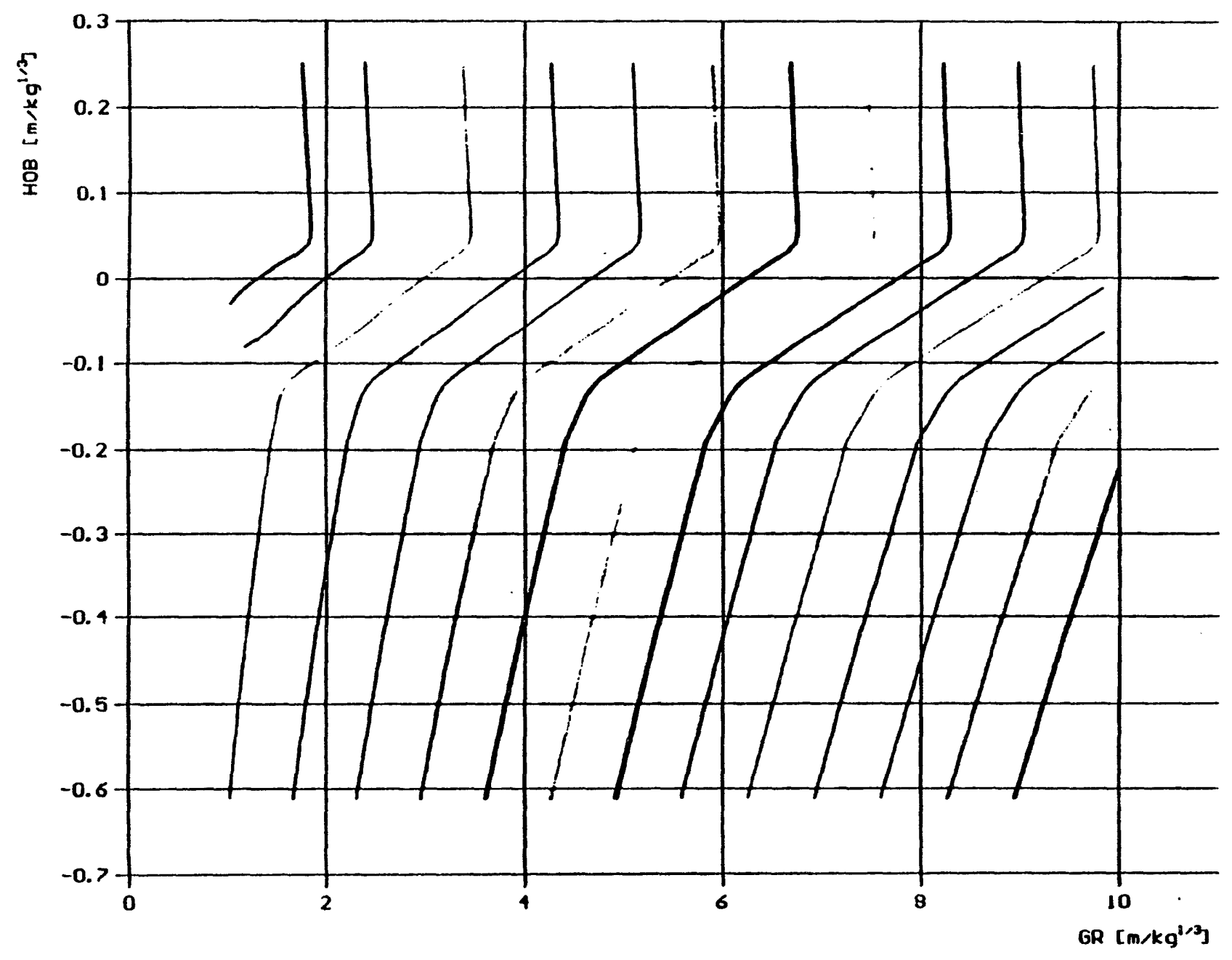

- $\left.T_{A}=0.00\right]\left[\sec / \mathrm{kg}^{1 / 3}\right]$

$-T_{A}=0.002\left[\sec / \mathrm{kg}^{1 / 3}\right]$

$\cdots I A=0.004\left[\sec / k^{1 / 3}\right]$

- TA $=0.006\left[\mathrm{sec} / \mathrm{kg}^{1 / 3}\right]$

- IA $=0.008\left[\sec / \mathrm{kg}^{1 / 3}\right]$

$I_{A}=0.01\left[\sec / \mathrm{kg}^{1 / 3}\right]$

- IA $=0.012\left[\sec / \mathrm{kg}^{1 / 3}\right]$

$T A=0.014\left[\sec / \mathrm{kg}^{1 / 3}\right]$

- IA $=0.016\left[\mathrm{sec} / \mathrm{kg}^{1 / 3}\right]$

- TA $=0.018\left[\sec / k g^{1 / 3}\right]$

- $T_{A}=0.02\left[\sec / k^{1 / 3}\right]$

- TA $=0.022\left[\sec / \mathrm{kg}^{1 / 3}\right]$

- TA $=0.024\left[\sec / \mathrm{kg}^{1 / 3}\right]$

- TA $=0.026\left[\sec / k^{2 / 3}\right]$

TA $=0.028\left[\sec / k g^{1 / 3}\right]$

Figure 35b. Constant arrival time DOB curves for water-saturated grout (wet YTONG) Polygon approximation 


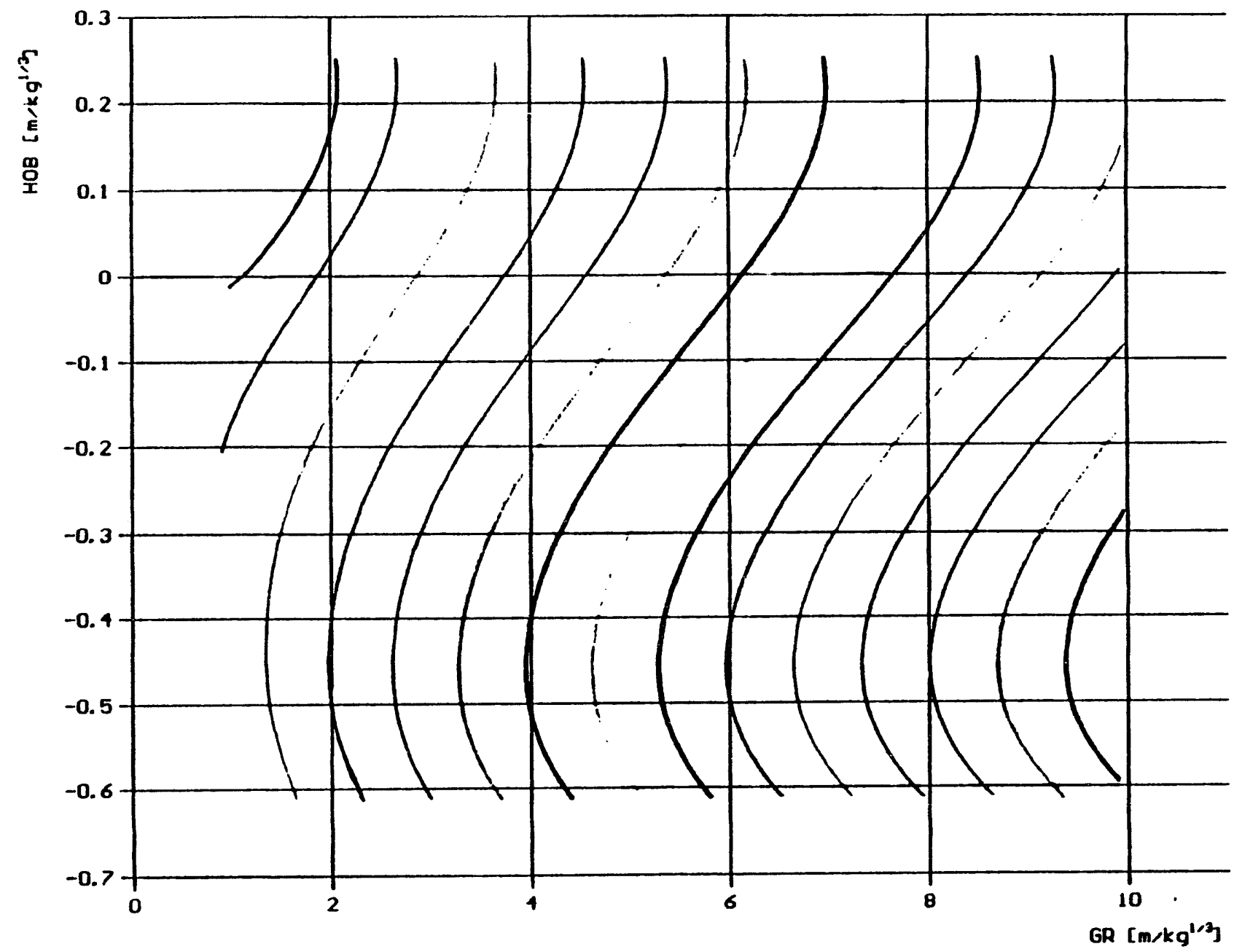

- IA $=0.001\left[\mathrm{sec} / \mathrm{kg}^{1 / 3}\right]$

- $T_{A}=0.002\left[\mathrm{sec} / \mathrm{kg}^{1 / 3}\right]$

- $T_{A}=0.001\left[\mathrm{sec} / \mathrm{kg}^{1 / 3}\right]$

- $\mathrm{IA}_{\mathrm{A}}=0.006\left[\sec / \mathrm{kg}^{1 / 3}\right]$

- TA $=0.008\left[\sec / \mathrm{kg}^{1 / 3}\right]$

.... $T_{A}=0.01\left[\mathrm{sec} / \mathrm{kg}^{1 / 3}\right]$

- TA $=0.012\left[\mathrm{sec} / \mathrm{kg}^{2 / 3}\right]$

$T_{A}=0.014\left[\mathrm{sec} / \mathrm{kg}^{1 / 3}\right]$

- $T_{A}=0.016\left[\mathrm{sec} / \mathrm{kg}^{1 / 3}\right]$

- $T_{A}=0.018\left[\mathrm{sec} / \mathrm{kg}^{1 / 3}\right]$

- . $T A=0.02\left[\mathrm{sec} / \mathrm{kg}^{1 / 3}\right]$

- $T_{A}=0.022\left[\mathrm{sec} / \mathrm{kg}^{1 / 3}\right]$

- TA $=0.024\left[\sec / \mathrm{kg}^{1 / 3}\right]$

- $T A=0.026\left[\mathrm{sec} / \mathrm{kg}^{1 / 3}\right]$

- TA $=0.028\left[\sec / \mathrm{kg}^{1 / 3}\right]$

Figure 35c. Constant arrival time DOB curves for water-saturated grout (wet YTONG) Polynomial approximation 


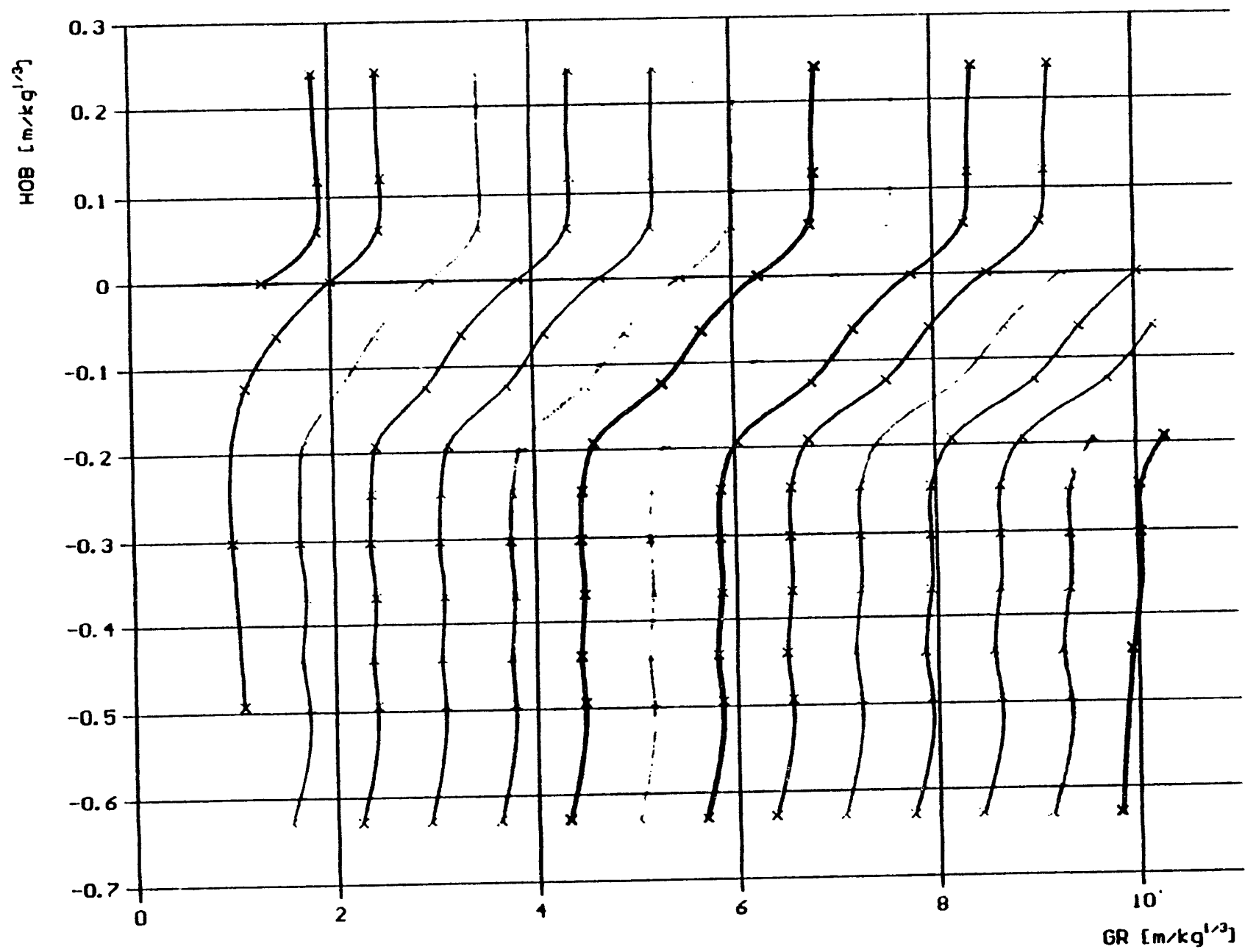

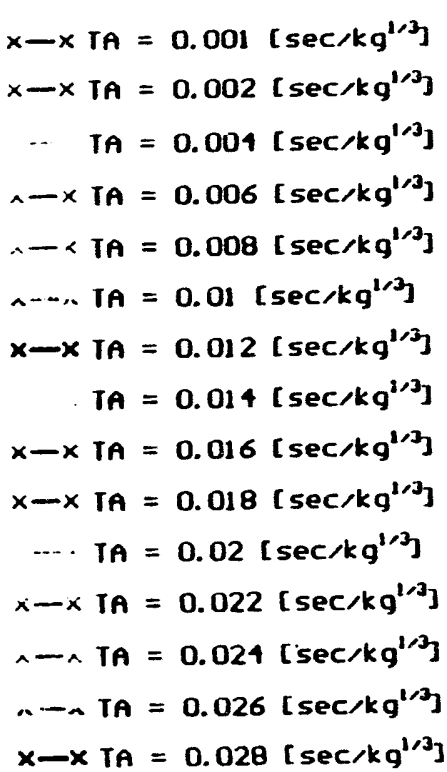

Figure 36a. Constant arrival time DOB curves for wet clay/loam Spline function approximation 


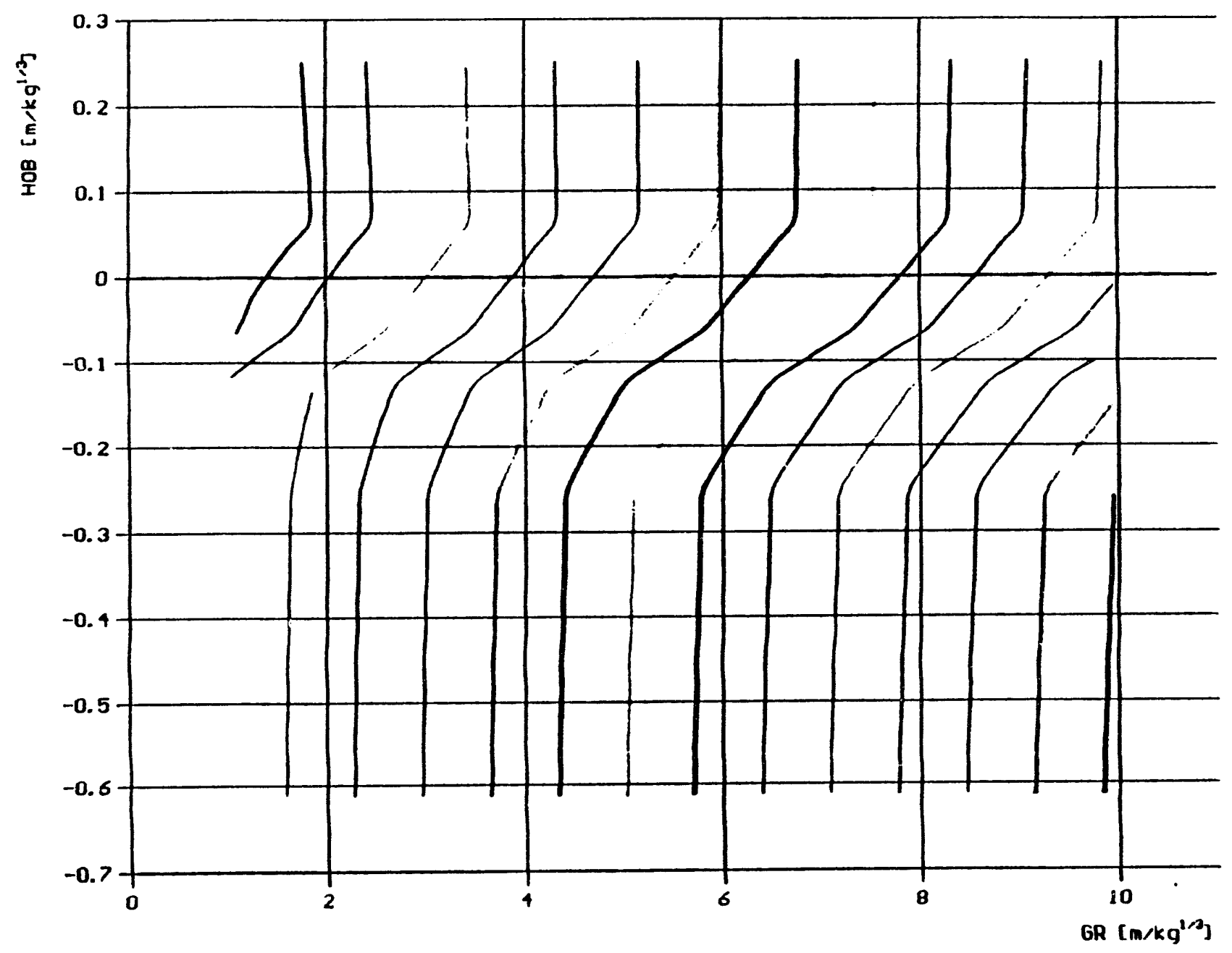

- $T A=0.001\left[\mathrm{sec} / \mathrm{kg}^{1 / 3}\right]$

- $T_{A}=0.002\left[\sec / \mathrm{kg}^{1 / 3}\right]$

$\cdots T_{A}=0.004\left[\sec / k^{1 / 3}\right]$

- TA $=0.006\left[\mathrm{sec} / \mathrm{kg}^{1 / 3}\right]$

- TA $=0.008\left[\sec / \mathrm{kg}^{1 / 3}\right]$

$\cdots \rightarrow I A=0.01\left[\sec / \mathrm{kg}^{1 / 3}\right]$

- TA $=0.012\left[\sec / \mathrm{kg}^{1 / 3}\right]$

$I A=0.014\left[\sec / \mathrm{kg}^{1 / 3}\right]$

$-T_{A}=0.016\left[\mathrm{sec} / \mathrm{kg}^{1 / 3}\right]$

- TA $=0.018\left[\sec / \mathrm{kg}^{1 / 3}\right]$

- TA $=0.02\left[\sec / \mathrm{kg}^{1 / 3}\right]$

- TA $=0.022\left[\sec / \mathrm{kg}^{1 / 3}\right]$

- TA $=0.024\left[\mathrm{sec} / \mathrm{kg}^{1 / 3}\right]$

IA $=0.026[$ sec/kg $/ 3]$

- TA $=0.028\left[\mathrm{sec} / \mathrm{kg}^{1 / 3}\right]$

Figure 36b. Constant arrival time DOB curves for wet clay/loam

Polygon approximation 


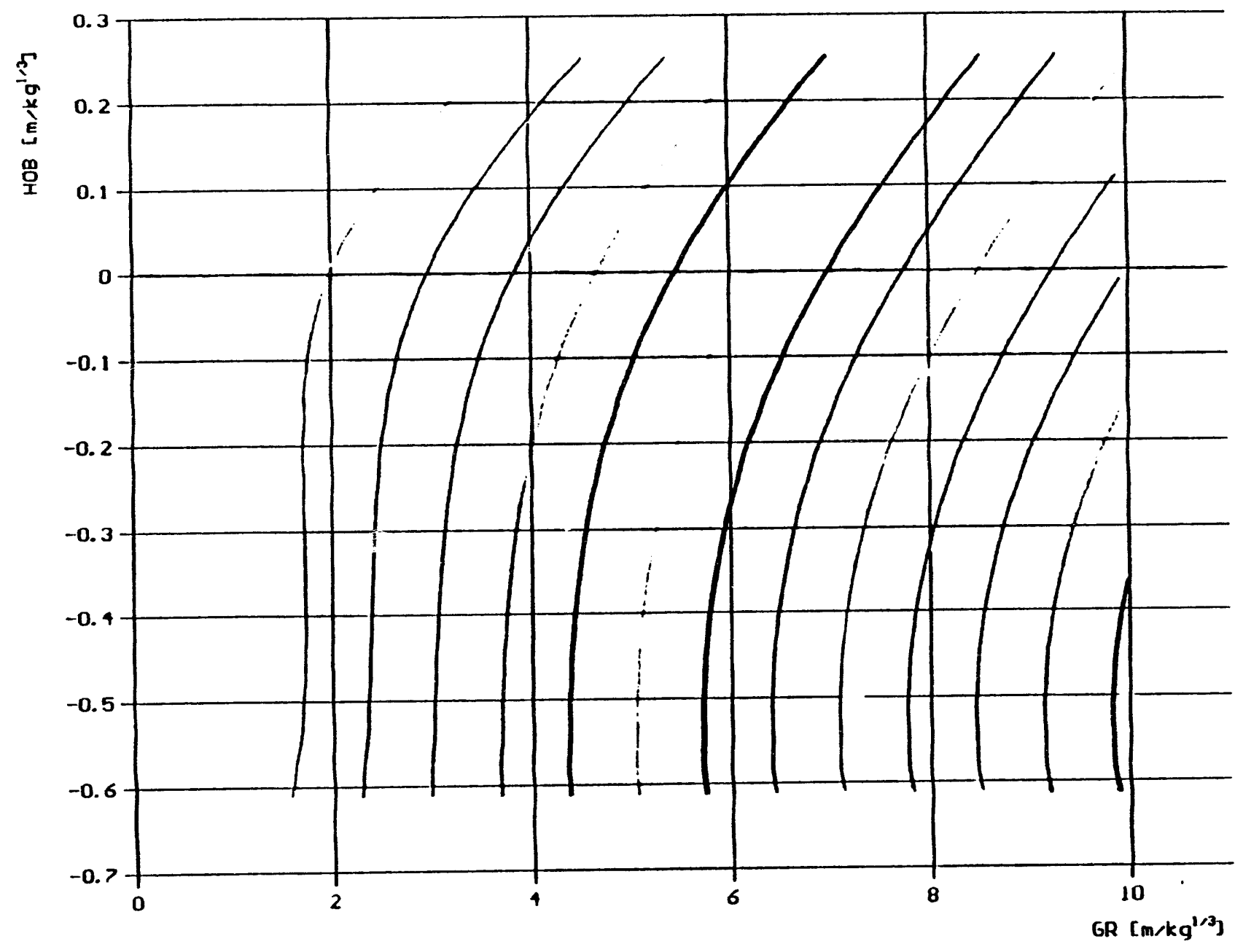

$I A=0.004\left[\mathrm{sec} / \mathrm{kg}^{1 / 3}\right]$

- IA $=0.006\left[\sec / \mathrm{kg}^{1 / 3}\right]$

$-I_{A}=0.008\left[\sec / \mathrm{kg}^{1 / 3}\right]$

- $T A=0.01\left[\sec / \mathrm{kg}^{1 / 3}\right]$

$-T_{A}=0.012\left[\mathrm{sec} / \mathrm{kg}^{1 / 3}\right]$

$I A=0.014\left[\sec / k^{1 / 3}\right]$

$I_{\text {IA }}=0.016\left[\mathrm{sec} / \mathrm{kg}^{1 / 3}\right]$

$-I_{A}=0.018\left[\mathrm{sec} / \mathrm{kg}^{1 / 3}\right]$

$\ldots$ IA $=0.02\left[\sec / \mathrm{kg}^{1 / 3}\right]$

$-T_{A}=0.022\left[\sec / \mathrm{kg}^{1 / 3}\right]$

$-T_{A}=0.024\left[\sec / \mathrm{kg}^{1 / 3}\right]$

- . TA $=0.026\left[\mathrm{sec} / \mathrm{kg}^{1 / 3}\right]$

$-T_{A}=0.028\left[\mathrm{sec} / \mathrm{kg}^{1 / 3}\right]$

Figure 36c. Constant arrival time DOB curves for wet clay/loam

Polynomial approximation 


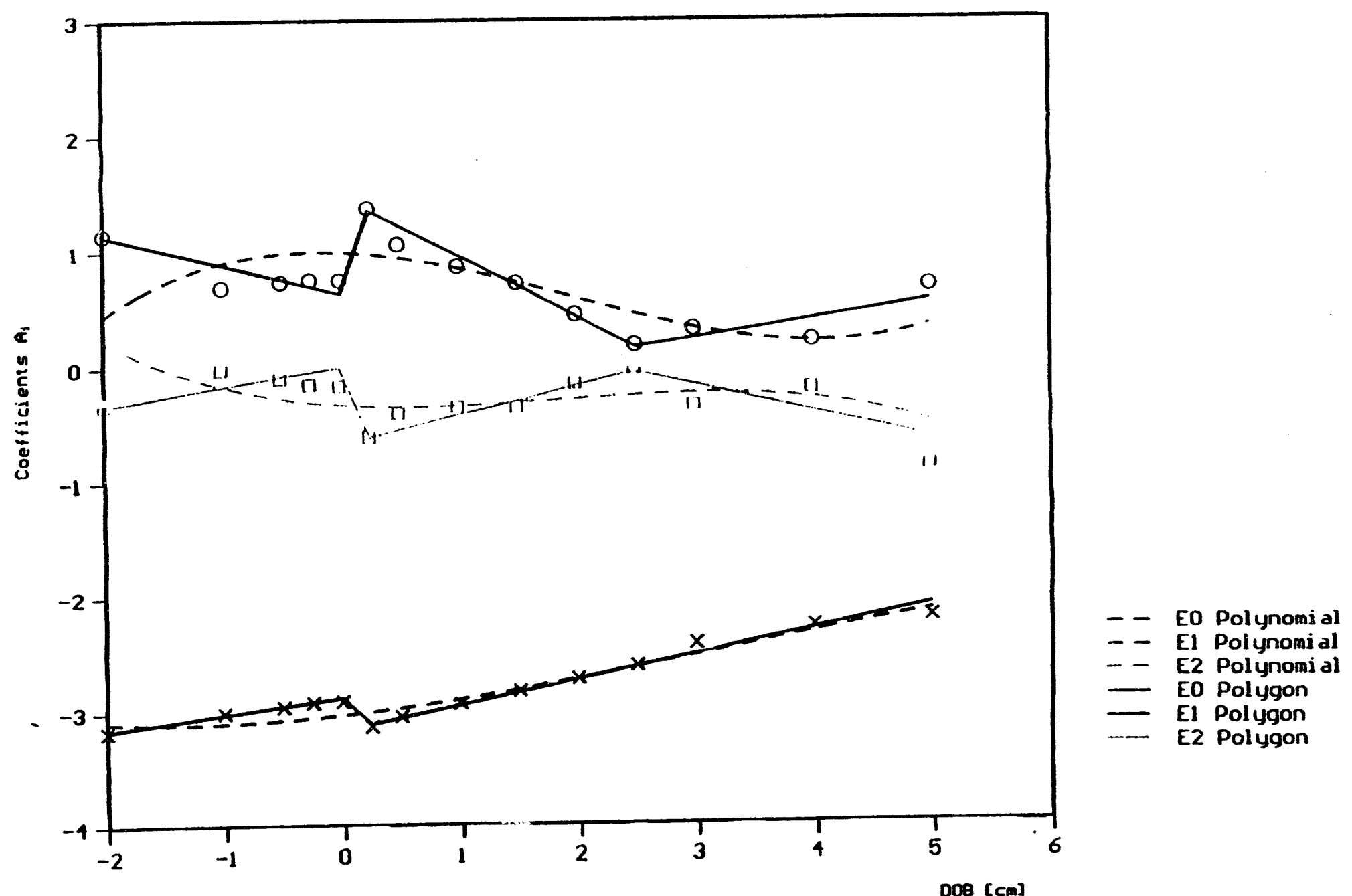

Figure 37. Coefficients of approximation functions for positive phase duration vs ground range at different $\mathrm{DOB}$.

Aerated grout (diy YTONG); polynomial and polygon approximation 


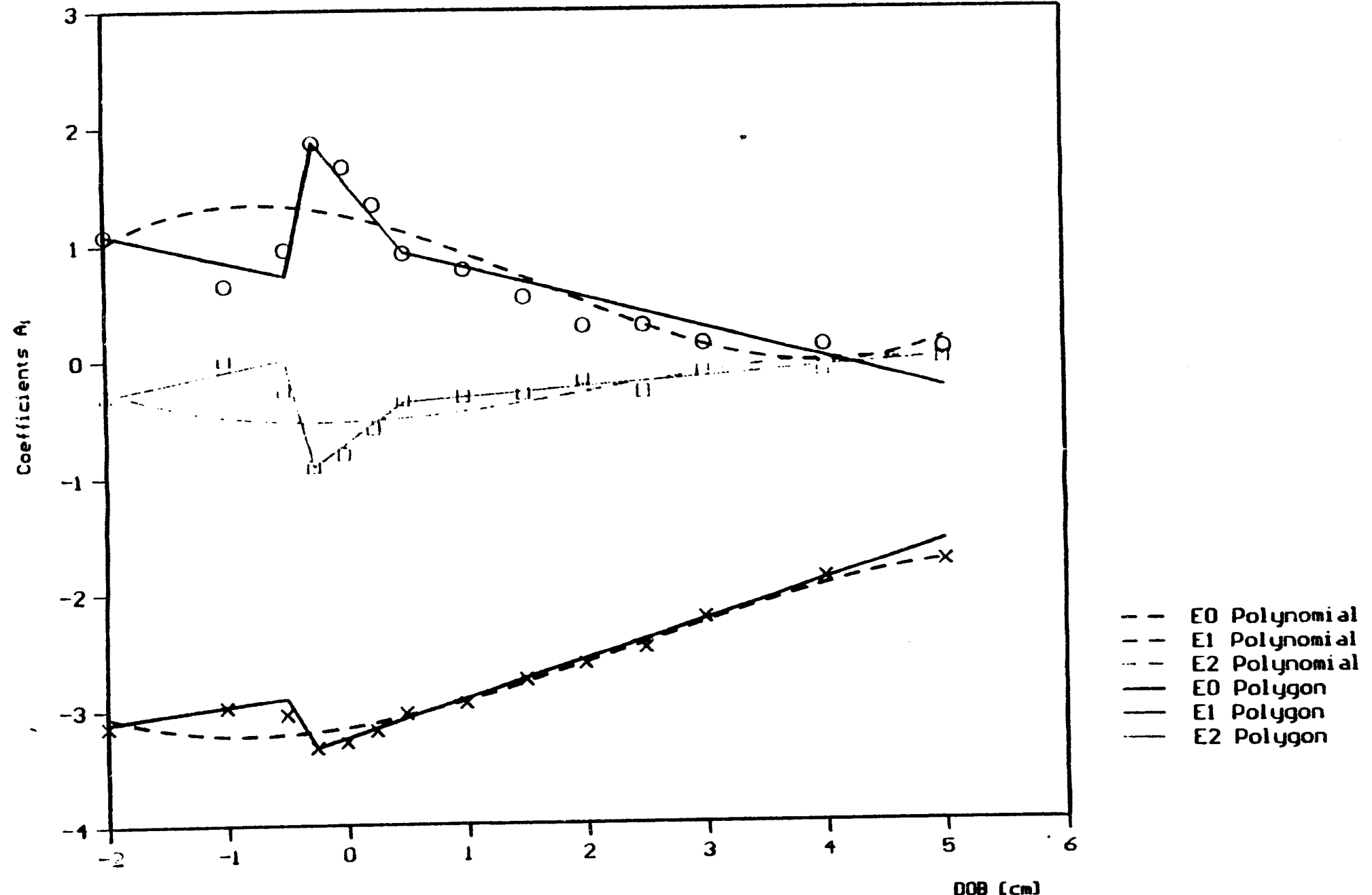

Figure 38. Coefficients of approximation functions for positive phase duration vs ground range at different DOB.

Water-saturated grout (wet YTONG); polynomial and polygon approximation 


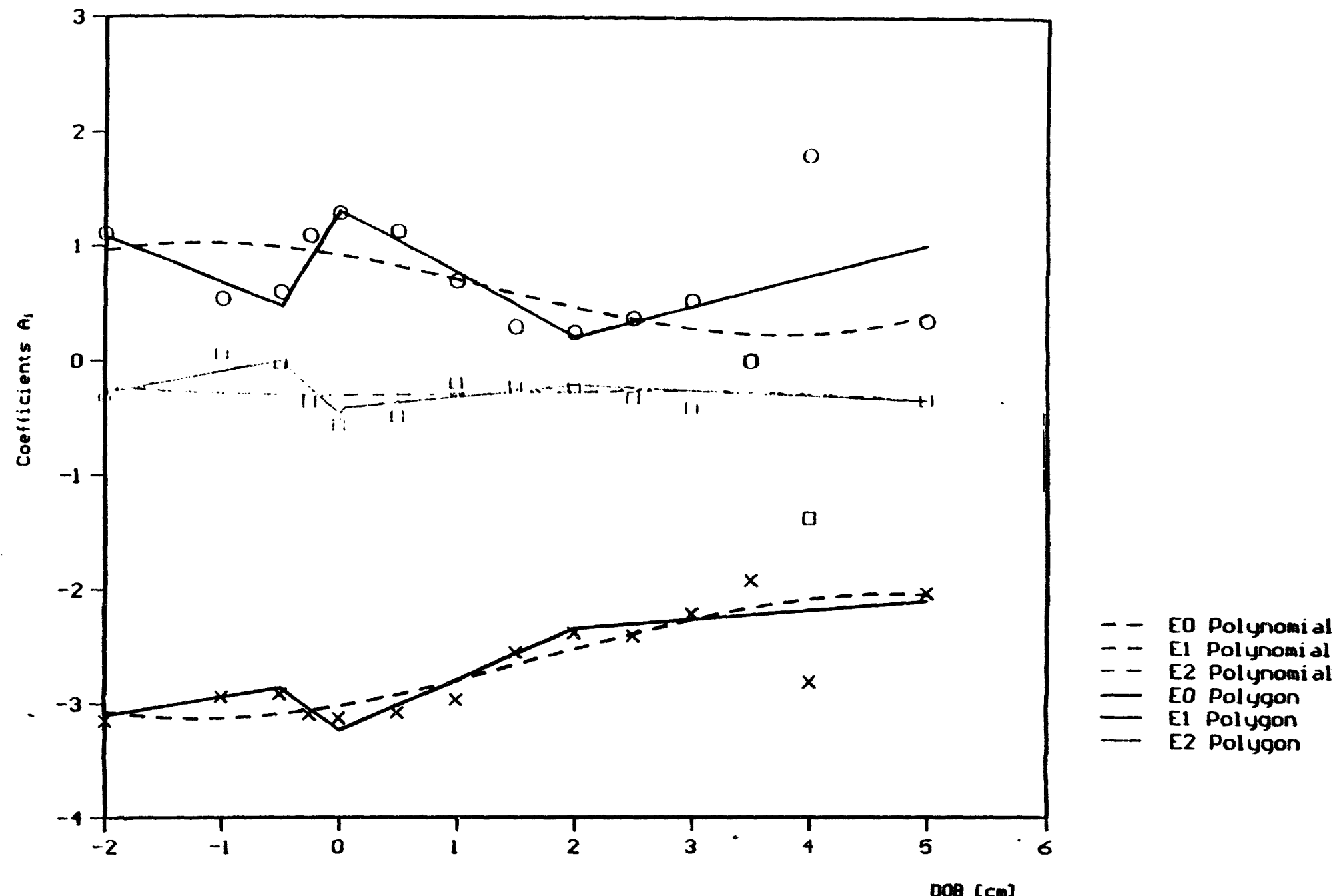

Figure 39. Coefficients of approximation functions for positive phase duration vs ground range at different DOB.

Wet clay/loam; polynomial and polygon approximation 

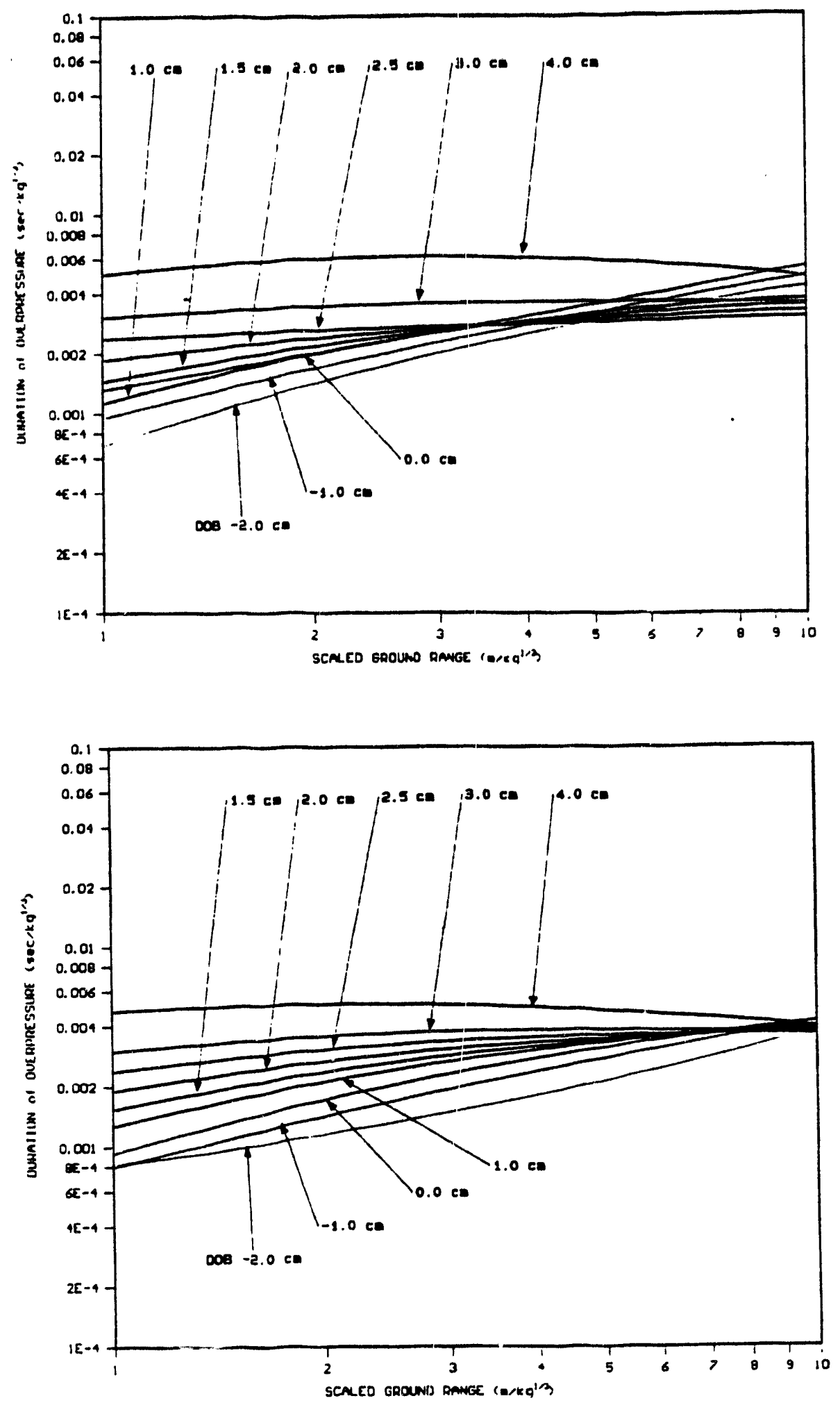

Figure 40. Positive phase duration vs ground range curves for different DOB. Aerated grout (dry YTONG)

(a) polygon approximation

(b) polynomial approximation 

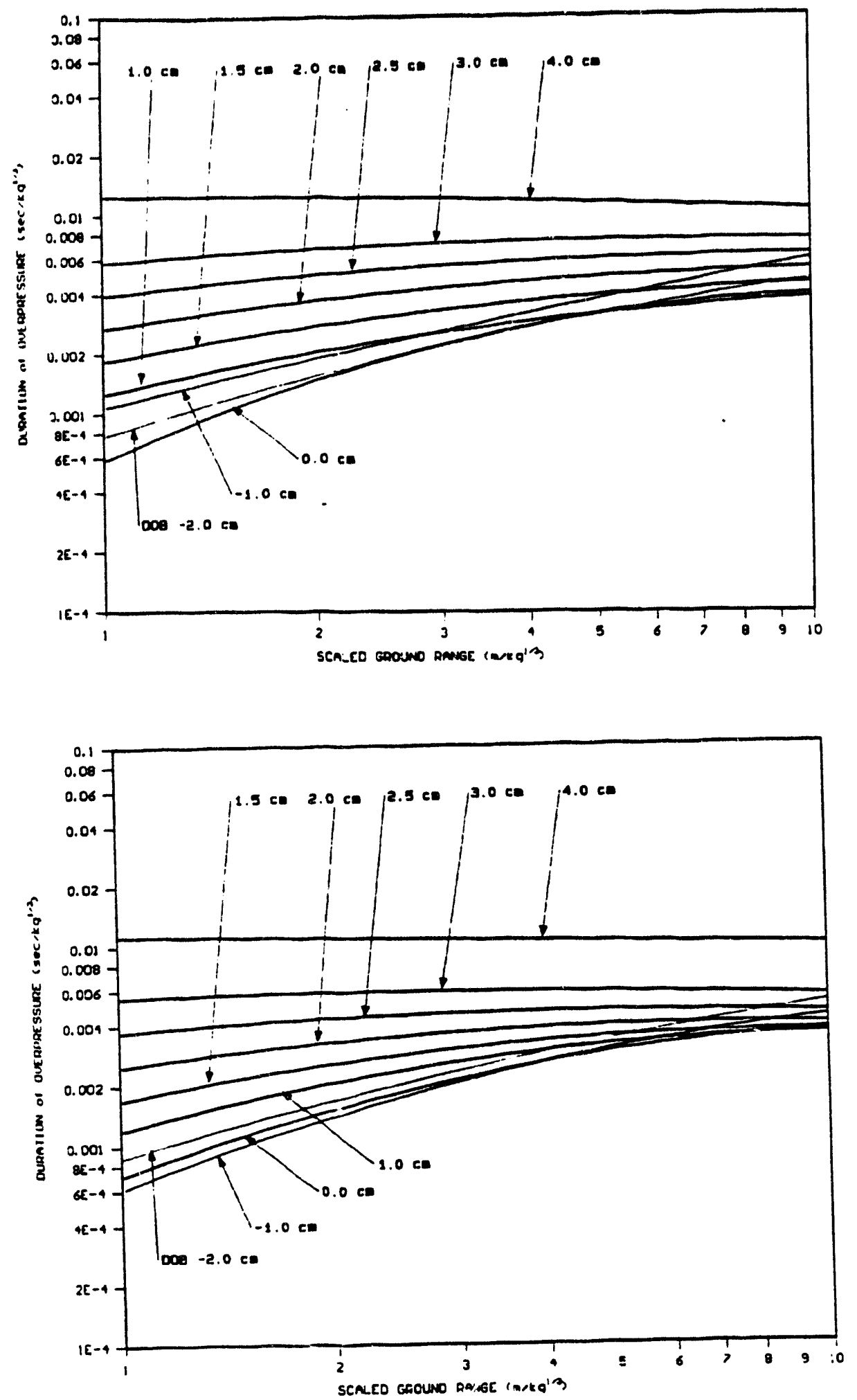

Figure 41. Pusitive phase duration vs ground range curves for different DOB. Water-saturated grout (wet YTONG)
(a) polygon approximation
(b) polynomial approximation 


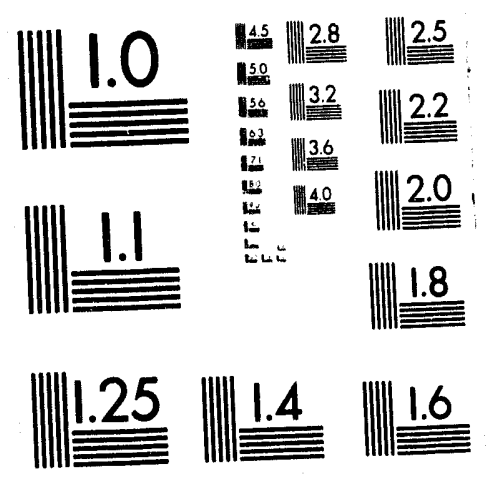



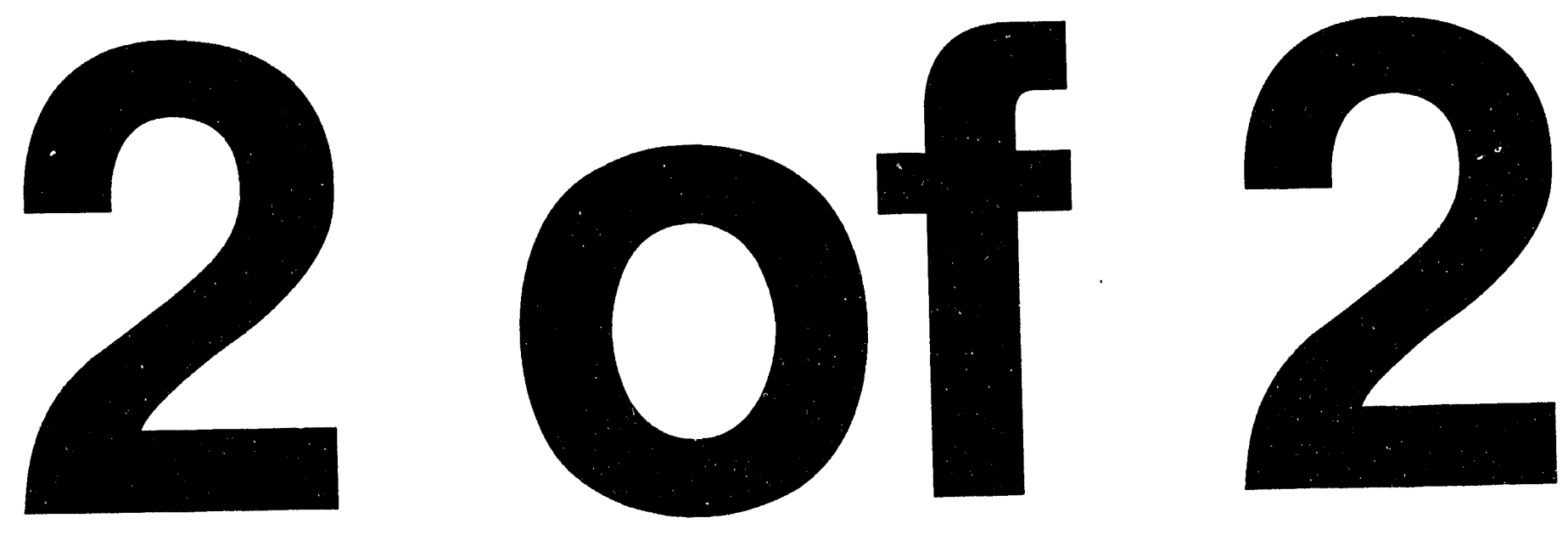


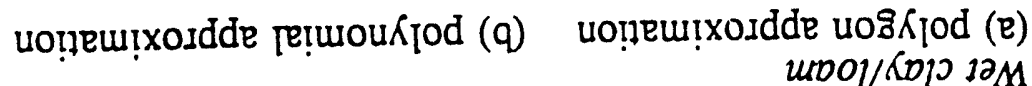

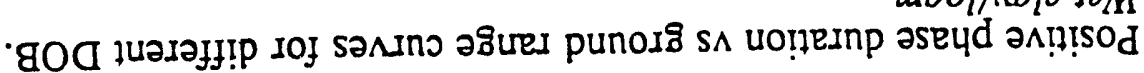
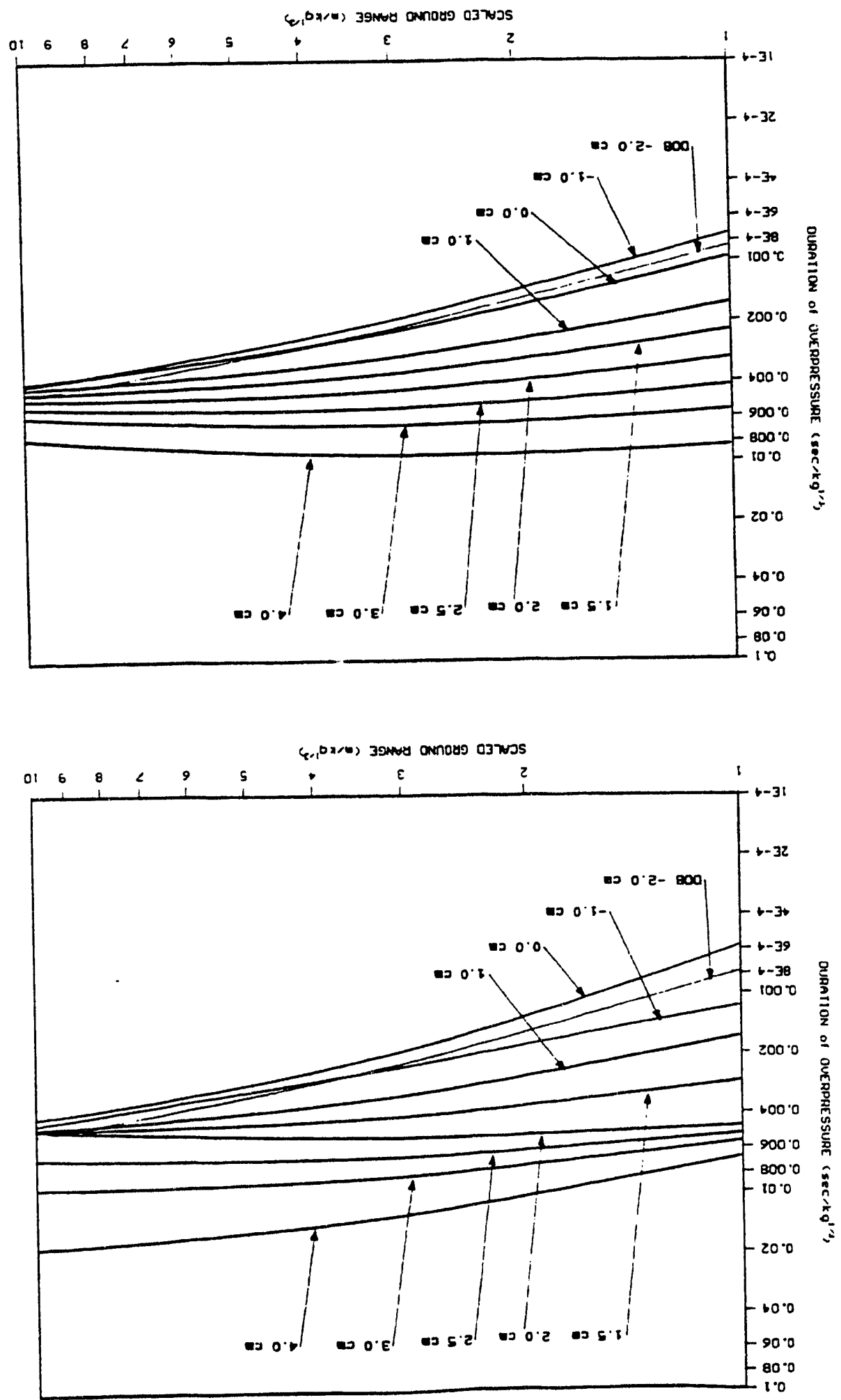


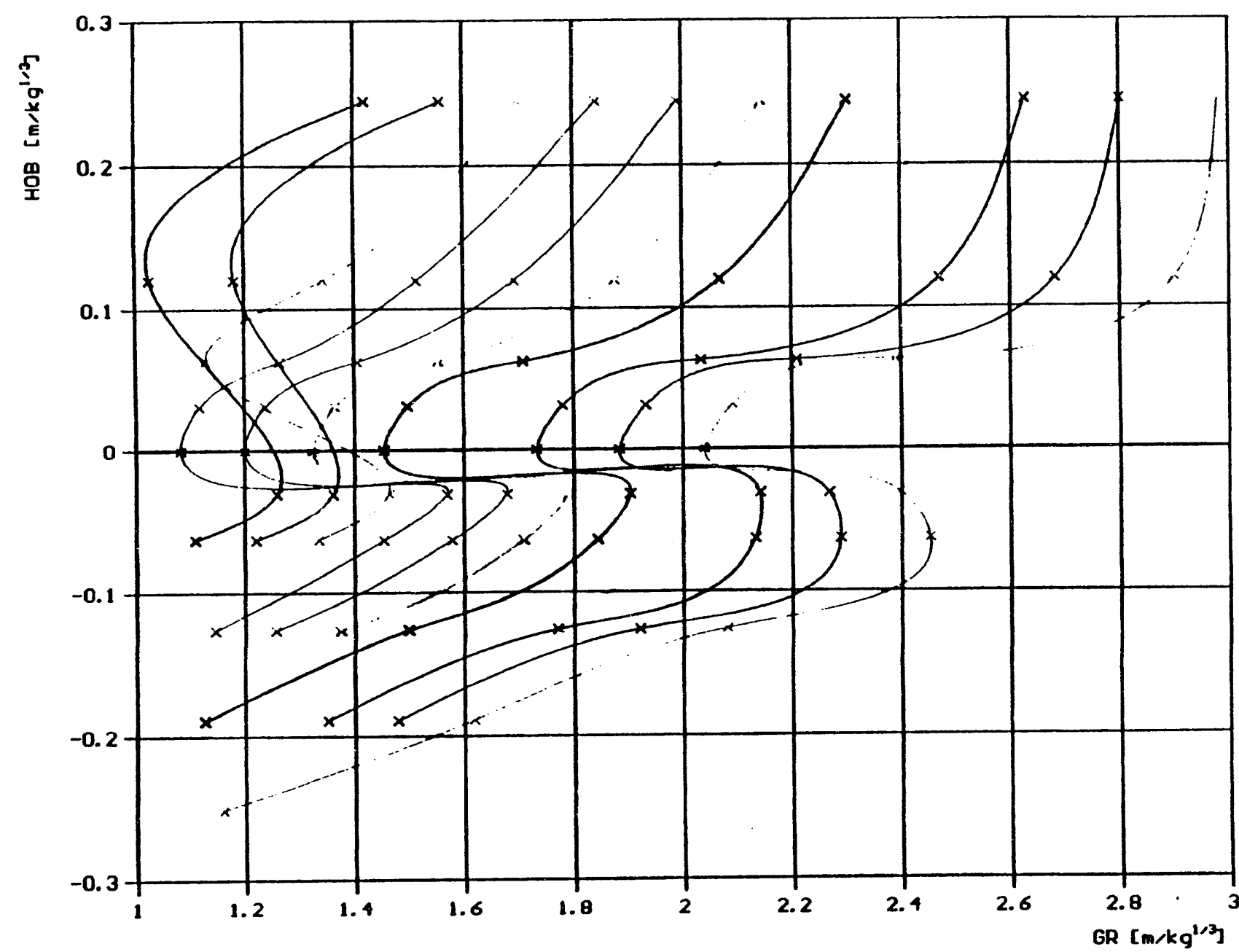

$x-x T+=0.001\left[\sec / k^{1 / 3}\right]$

$x-x \mathrm{~T}+=0.0011\left[\sec / \mathrm{kg}^{1 / 3}\right]$

$\cdots, T_{t}=0.0012\left[\mathrm{sec} / \mathrm{kg}^{1 / 3}\right]$

$x-x T_{+}=0.0013\left[\mathrm{sec} / \mathrm{kg}^{1 / 3}\right]$

$x--x T+=0.0014\left[\sec / k^{1 / 3}\right]$

$\therefore r \therefore \mathrm{T}+=0.0015\left[\mathrm{sec} / \mathrm{kg}^{1 / 3}\right]$

$x-X I+=0.0016\left[\sec / k^{1 / 3}\right]$

$T+=0.0017\left[\mathrm{sec} / \mathrm{kg}^{1 / 3}\right]$

$x-x I+=0.0018\left[\sec / k^{1 / 3}\right]$

$x-x T+=0.0019\left[\sec / k^{1 / 3}\right]$

$x \rightarrow x T+=0.002\left[\sec / k^{1 / 3}\right]$

Figure 43a. Constant duration DOB curves for dry aerated grout (dry YTONG) Spline function approximation 


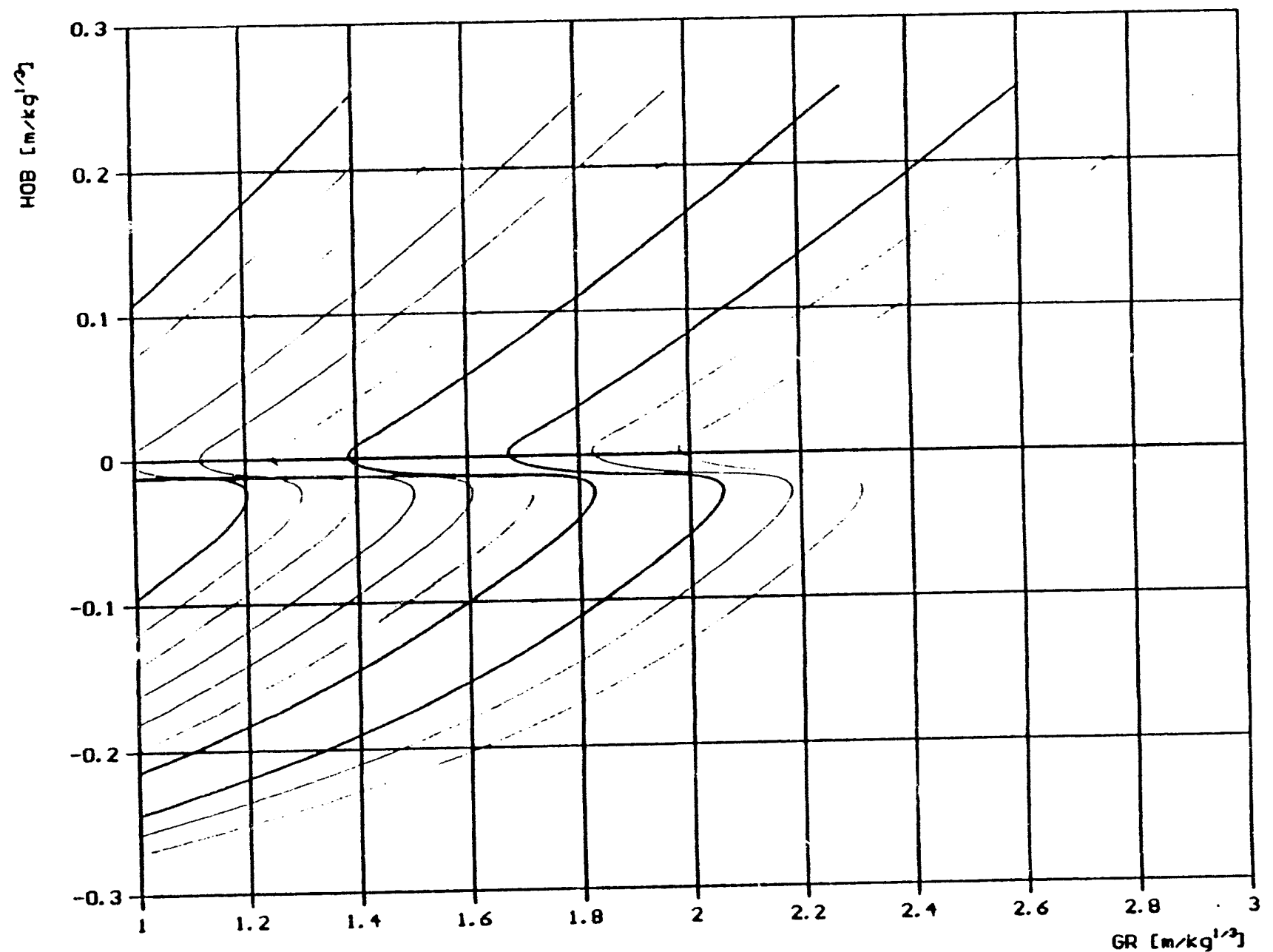

$-T_{t}=0.001\left[\sec / \mathrm{kg}^{1 / 3}\right]$

- $T_{+}=0.0011\left[\sec / \mathrm{kg}^{1 / 3}\right]$ $T_{t}=0.0012\left[\sec / \mathrm{kg}^{2 / 3}\right]$

$-T_{+}=0.0013\left[\mathrm{sec} / \mathrm{kg}^{3 / 3}\right]$

$-T_{+}=0.0014\left[\mathrm{sec} / \mathrm{kg}^{1 / 3}\right.$

$T_{+}=0.0015\left[\sec / \mathrm{kg}^{\mathrm{s} / 3}\right]$

$-T_{+}=0.0016\left[\mathrm{sec} / \mathrm{kg}^{1 / 3}\right]$ $T_{+}=0.0017\left[\sec / \mathrm{kg}^{1 / 3}\right]$

$-T_{t}=0.0018\left[\sec / \mathrm{kg}^{2 / 3}\right]$

$T_{+}=0.0019\left[\mathrm{sec} / \mathrm{kg}^{1 / 3}\right]$

$-T_{+}=0.002\left[\sec / \mathrm{kg}^{1 / 3}\right]$

Figure 43b. Constant duration DOB curves for dry aerated grout (dry YTONG) Polygon approximation 


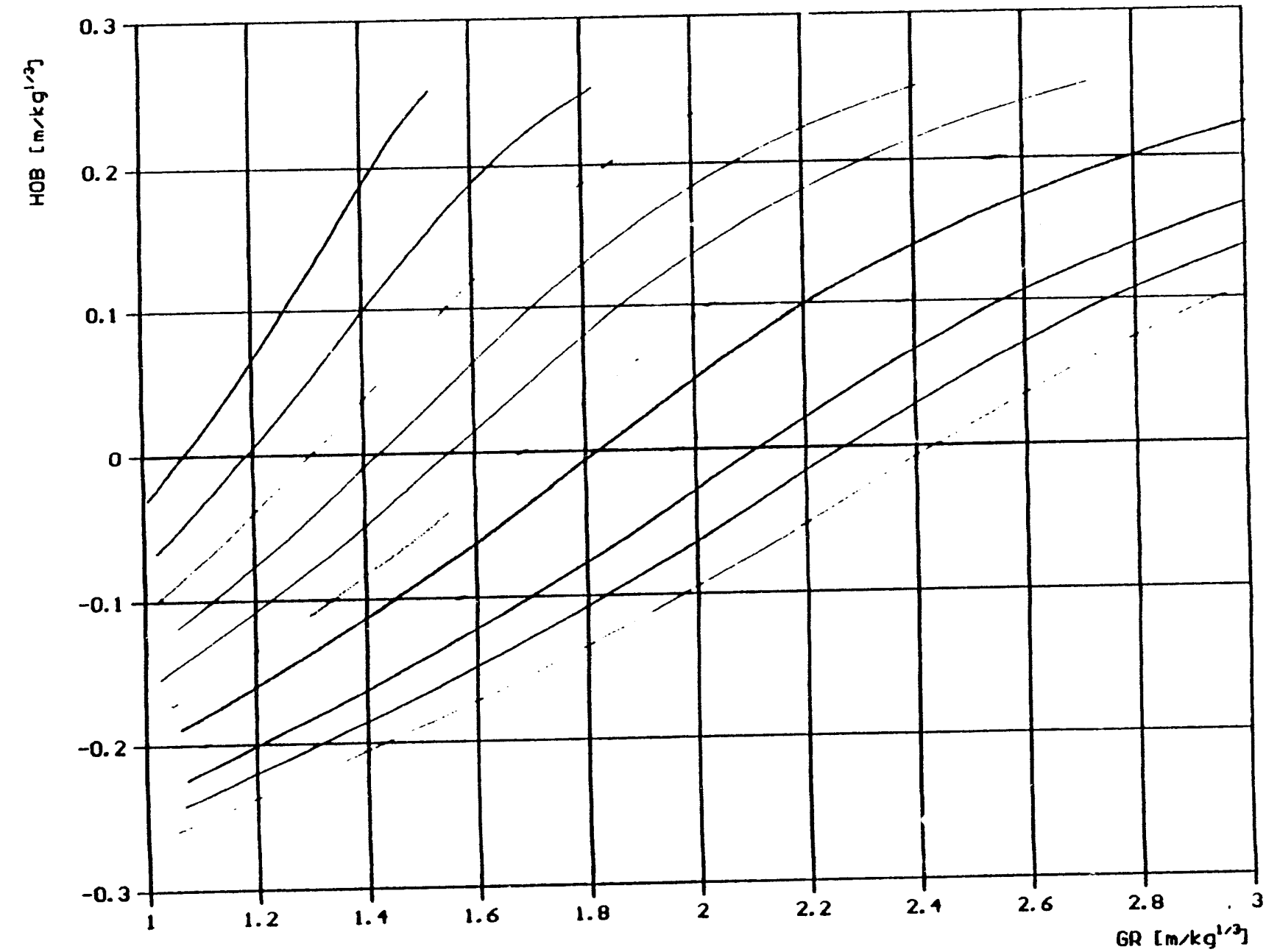

$-T_{+}=0.001\left[\sec / \mathrm{kg}^{1 / 3}\right]$

$T_{+}=0.0011\left[\sec / \mathrm{kg}^{1 / 3}\right]$

$\mathrm{I}+=0.0012\left[\mathrm{sec} / \mathrm{kg}^{1 / 3}\right]$

$-T_{+}=0.0013\left[\sec / \mathrm{kg}^{1 / 3}\right]$

$\ldots-T_{+}=0.0014\left[\sec / \mathrm{kg}^{1 / 3}\right]$

.. $\mathrm{T}_{+}=0.0015\left[\mathrm{sec} / \mathrm{kg}^{1 / 3}\right]$

$-T_{+}=0.0016\left[\mathrm{sec} / \mathrm{kg}^{1 / 3}\right]$

$T+=0.0017\left[\sec / \mathrm{kg}^{1 / 3}\right]$

$-T_{+}=0.0018\left[\sec / \mathrm{kg}^{1 / 3}\right]$

$-\mathrm{T}+=0.0019\left[\mathrm{sec} / \mathrm{kg}^{2 / 3}\right]$

$\ldots T_{+}=0.002\left[\sec / \mathrm{kg}^{1 / 3}\right]$

Figure 43c. Constant duration DOB curves for dry aerated grout (dry YTONG) Polynomial approximation 


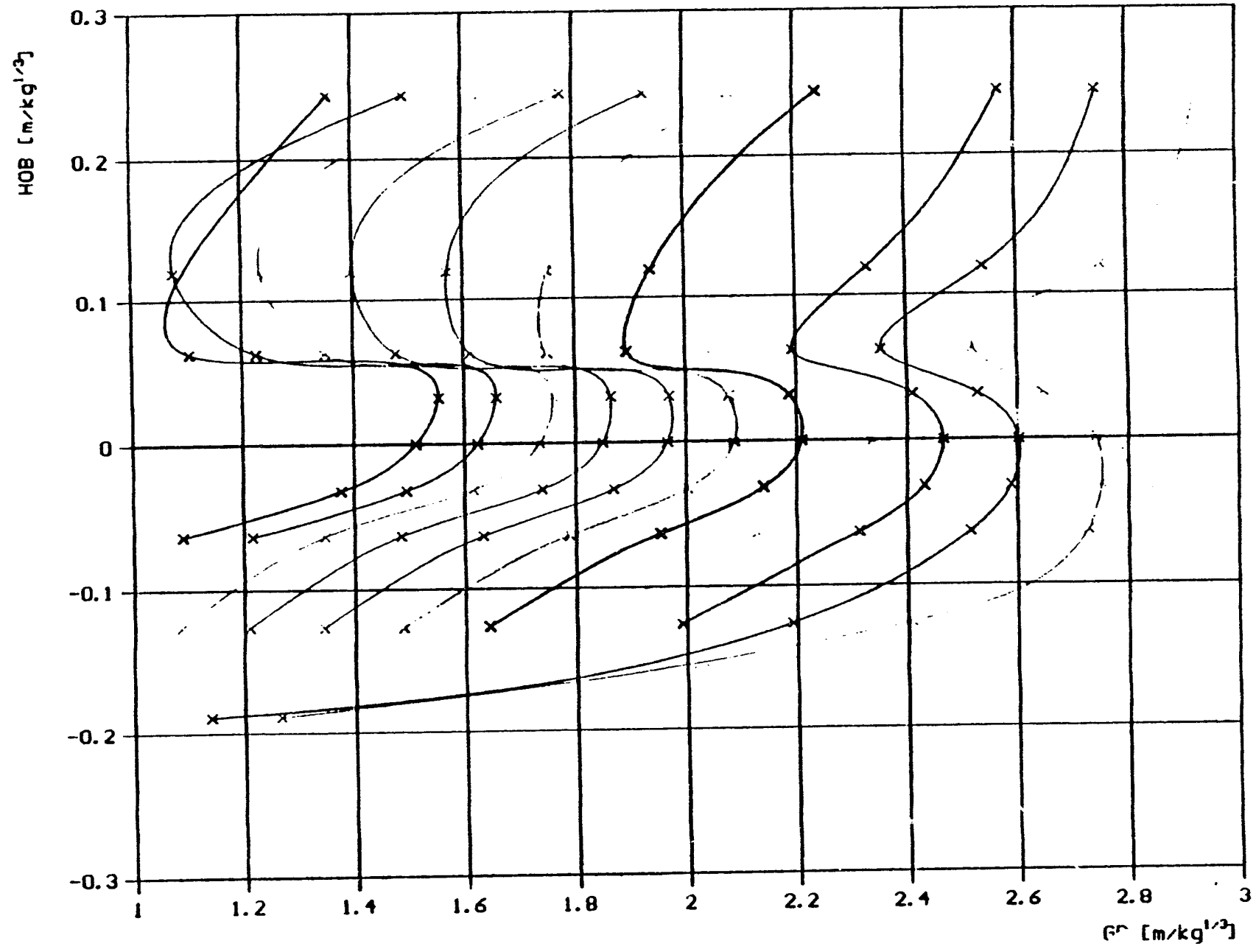

$x-X T+=0.001\left[\sec / k^{1 / 3}\right]$

$x-x T+=0.0011\left[\sec / \mathrm{kg}^{1 / 3}\right]$

$T+=0.0012\left[\sec / \mathrm{kg}^{1 / 3}\right]$

$x-x I+=0.0013\left[\sec / k^{1 / 3}\right]$

$\wedge-<T+=0.0014\left[\sec / k^{1 / 3}\right]$

$\therefore \therefore T+=0.0015\left[\mathrm{sec} / \mathrm{kg}^{1 / 3}\right]$

$x-x I+=0.0016\left[\mathrm{sec} / \mathrm{kq}^{1 / 3}\right]$

$\mathrm{T}+=0.0017\left[\mathrm{sec} / \mathrm{kq}^{1 / 3}\right]$

$x-x T+=0.0018\left[\sec / k g^{1 / 3}\right]$

$x-x T+=0.0019\left[\sec / k^{1 / 3}\right]$

$\wedge \cdots T+=0.002\left[\sec / k^{l / 3}\right]$

Figure 44a. Constant duration DOB curves for water-saturated grout (wet YTONG) Spline function approximation 


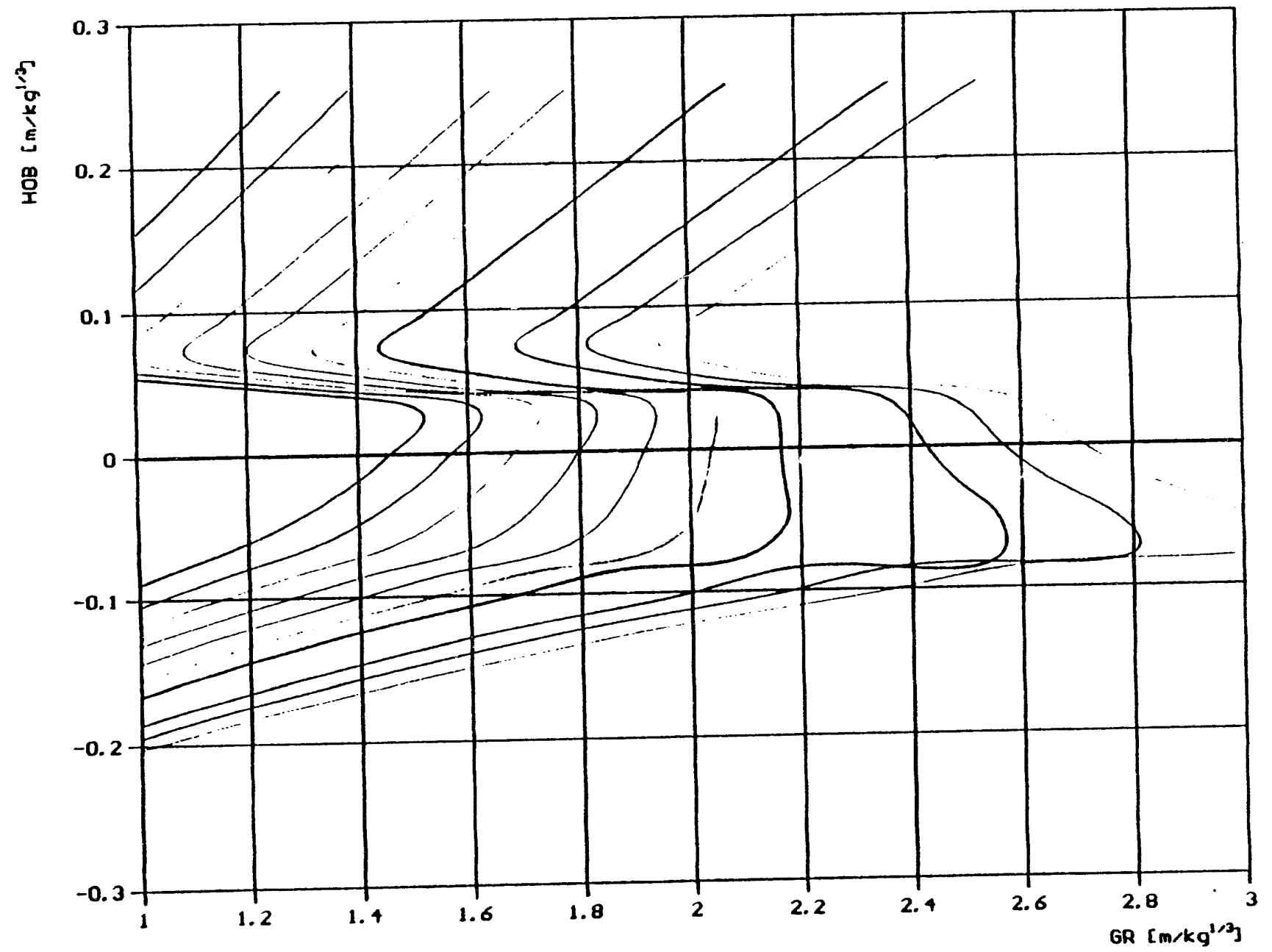

$-T_{+}=0.001\left[\sec / \mathrm{kg}^{1 / 3}\right]$

$T_{+}=0.0011\left[\mathrm{sec} / \mathrm{kq}^{1 / 3}\right]$

$T_{+}=0.0012\left[\sec / \mathrm{kq}^{1 / 3}\right]$

$\ldots+T_{+}=0.0013\left[\mathrm{sec} / \mathrm{kg}^{1 / 3}\right]$

$\ldots+T_{t}=0.0014\left[\sec / k q^{1 / 3}\right]$

$T_{+}=0.0015\left[\mathrm{sec} / \mathrm{kg}^{1 / 3}\right]$

$-I+=0.0016\left[\mathrm{sec} / \mathrm{kg}^{2 / 3}\right]$

$T+=0.0017\left[\sec / \mathrm{kg}^{1 / 3}\right]$

$-T+=0.0018\left[\mathrm{sec} / \mathrm{kg}^{1 / 3}\right]$

$-T+=0.0019\left[\sec / \mathrm{kg}^{1 / 3}\right]$

- $T_{+}=0.002\left[\sec / \mathrm{kg}^{\mathrm{i} / 3}\right]$

Figure 44b. Constant duration DOB curves for water-saturated grout (wet YTONG) Polygon approximation 


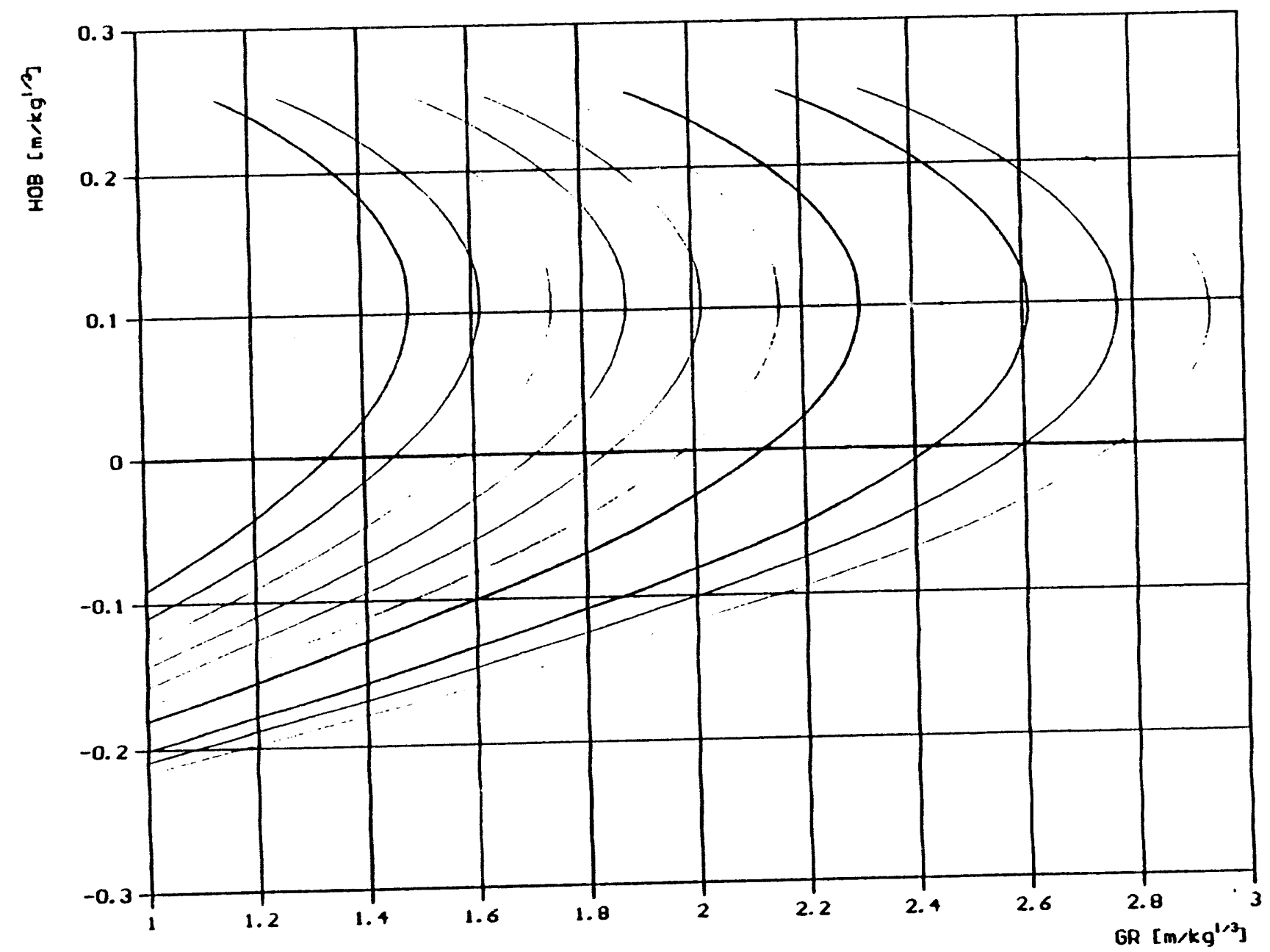

$T_{t}=0.001\left[\sec / k^{2 / 3}\right]$

$I_{t}=0.0011\left[\sec / \mathrm{kg}^{1 / 3}\right]$

$T_{+}=0.0012\left[\mathrm{sec} / \mathrm{kg}^{1 / 3}\right]$

$\ldots+T_{+}=0.0013\left[\mathrm{sec} / \mathrm{kg}^{1 / 3}\right]$

$-T+=0.0014\left[\sec / \mathrm{kg}^{1 / 3}\right]$

$\ldots T+=0.0015\left[\sec / \mathrm{kg}^{1 / 3}\right]$

$T_{+}=0.0016\left[\mathrm{sec} / \mathrm{kg}^{1 / 3}\right]$

$T_{t}=0.0017\left[\sec / \mathrm{kg}^{1 / 3}\right]$

$-T_{+}=0.0018\left[\mathrm{sec} / k^{1 / 3}\right]$

$T_{+}=0.0019\left[\sec / \mathrm{kg}^{1 / 3}\right]$

$T_{+}=0.002\left[\sec / k^{1 / 3}\right]$

Figure 44c. Constant duration DOB curves for water-saturated grout (wet YTONG) Polynomial approximation 


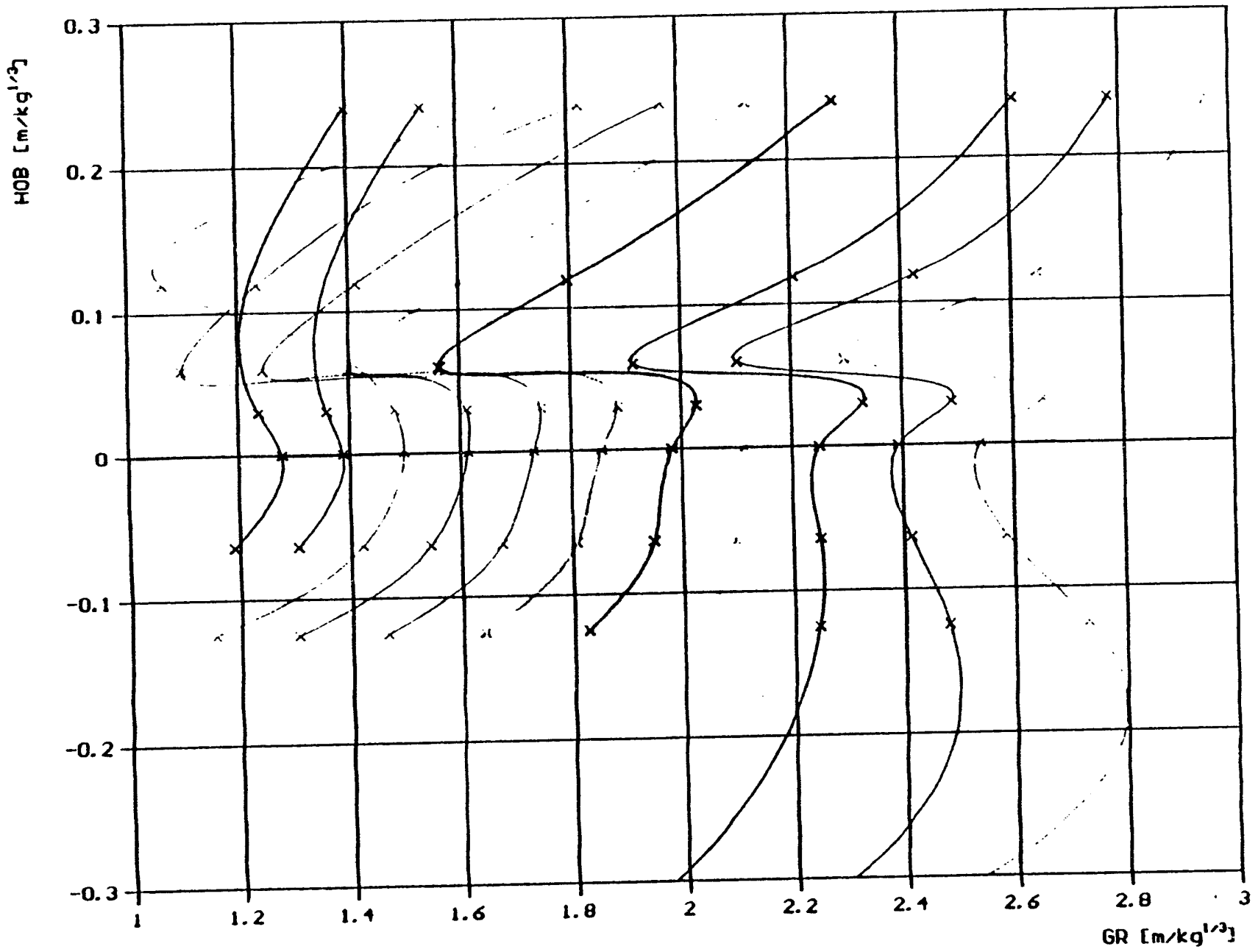

$$
\begin{aligned}
& x-x T+=0.001\left[\sec / k q^{1 / 3}\right] \\
& x-x T+=0.0011\left[\mathrm{sec} / \mathrm{kg}^{1 / 3}\right] \\
& I_{t}=0.0012\left[\sec / \mathrm{kg}^{1 / 3}\right] \\
& \times \cdots \times T_{+}=0.0013\left[\mathrm{sec} / \mathrm{kg}^{1 / 3}\right] \\
& \ldots T_{+}=0.0014\left[\sec / \mathrm{kg}^{1 / 3}\right] \\
& \text {... } \mathrm{T}_{+}=0.0015\left[\mathrm{sec} / \mathrm{kg}^{1 / 3}\right] \\
& x-X I+=0.0016\left[\sec / k^{1 / 3}\right] \\
& T+=0.0017\left[530 / \mathrm{kg}^{1 / \mathrm{s}}\right] \\
& x-x T+=0.0018\left[\sec / \mathrm{kg}^{1 / 3}\right] \\
& x-x T+=0.0019\left[\sec / k^{1 / 3}\right] \\
& \wedge \cdots T_{+}=0.002\left[\sec / \mathrm{kg}^{2 / 3}\right]
\end{aligned}
$$

Figure 45a. Constant duration DOB curves for clay/loam Spline function approximation 


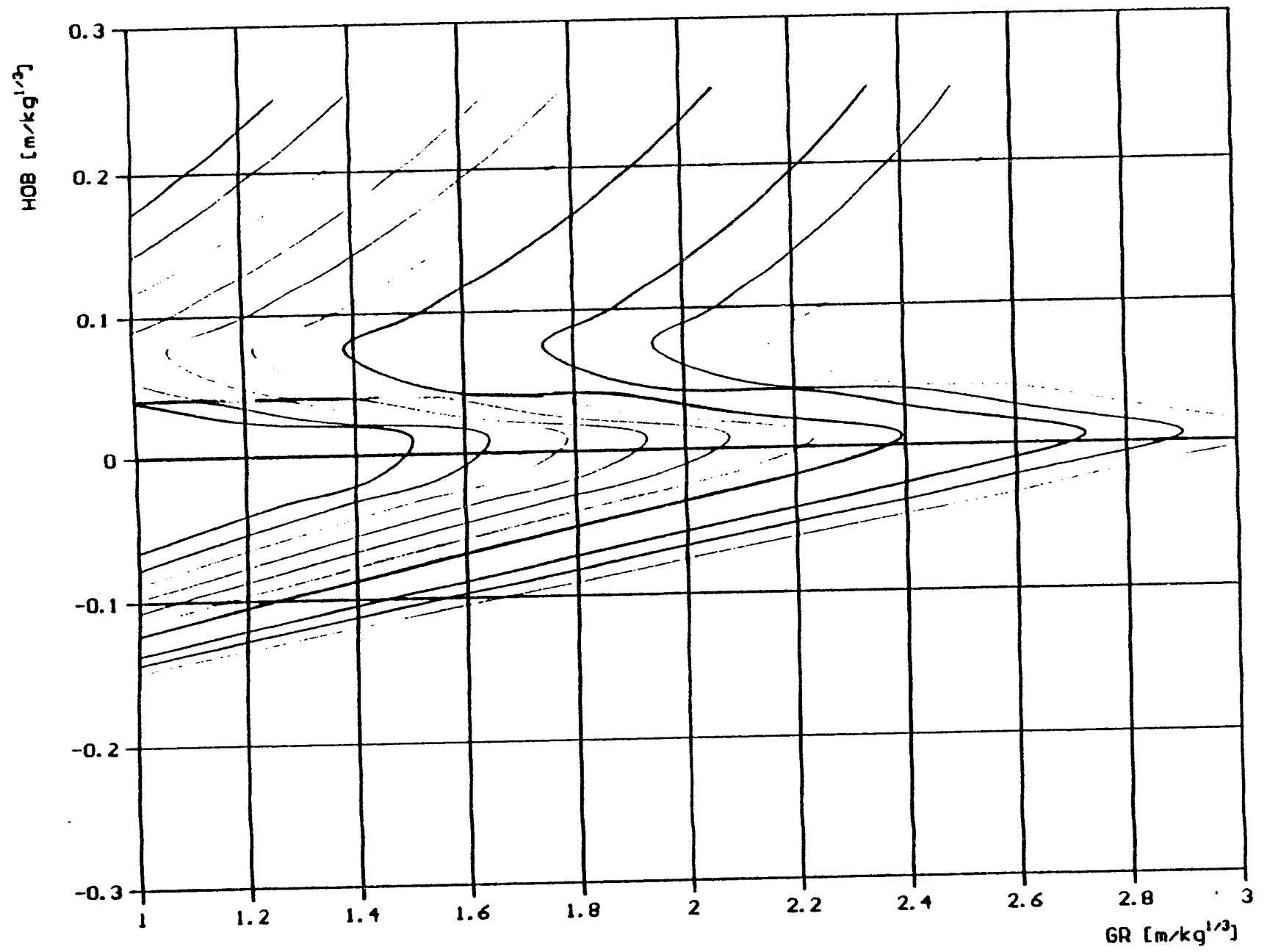

$-\mathrm{T}+=0.001\left[\sec / \mathrm{kg}^{1 / 3}\right]$

$\mathrm{T}_{t}=0.0011\left[\mathrm{sec} / \mathrm{kg}^{1 / 3}\right]$

$I+=0.0012\left[\mathrm{sec} / \mathrm{kg}^{1 / 3}\right]$

$\ldots+T_{+}=0.0013\left[\sec / \mathrm{kg}^{1 / 3}\right]$

. $T+=0.0014\left(\sec / k^{1 / 3}\right)$

$\mathrm{T}+=0.0015\left[\mathrm{sec} / \mathrm{kg}^{1 / 3}\right]$

$I+=0.0016\left[\mathrm{sec} / \mathrm{kg}^{1 / 3}\right]$

$T+=0.0017\left[\sec / \mathrm{kg}^{1 / 3}\right]$

$-T+=0.0018\left[\sec / \mathrm{kg}^{1 / 3}\right]$

$-T+=0.0019\left[\sec / k^{1 / 3}\right]$

$\ldots+T_{t}=0.002\left[\sec / \mathrm{kg}^{1 / 3}\right]$

Figure 45b. Constant duration DOB curves for clay/loam

Polygon approximation 


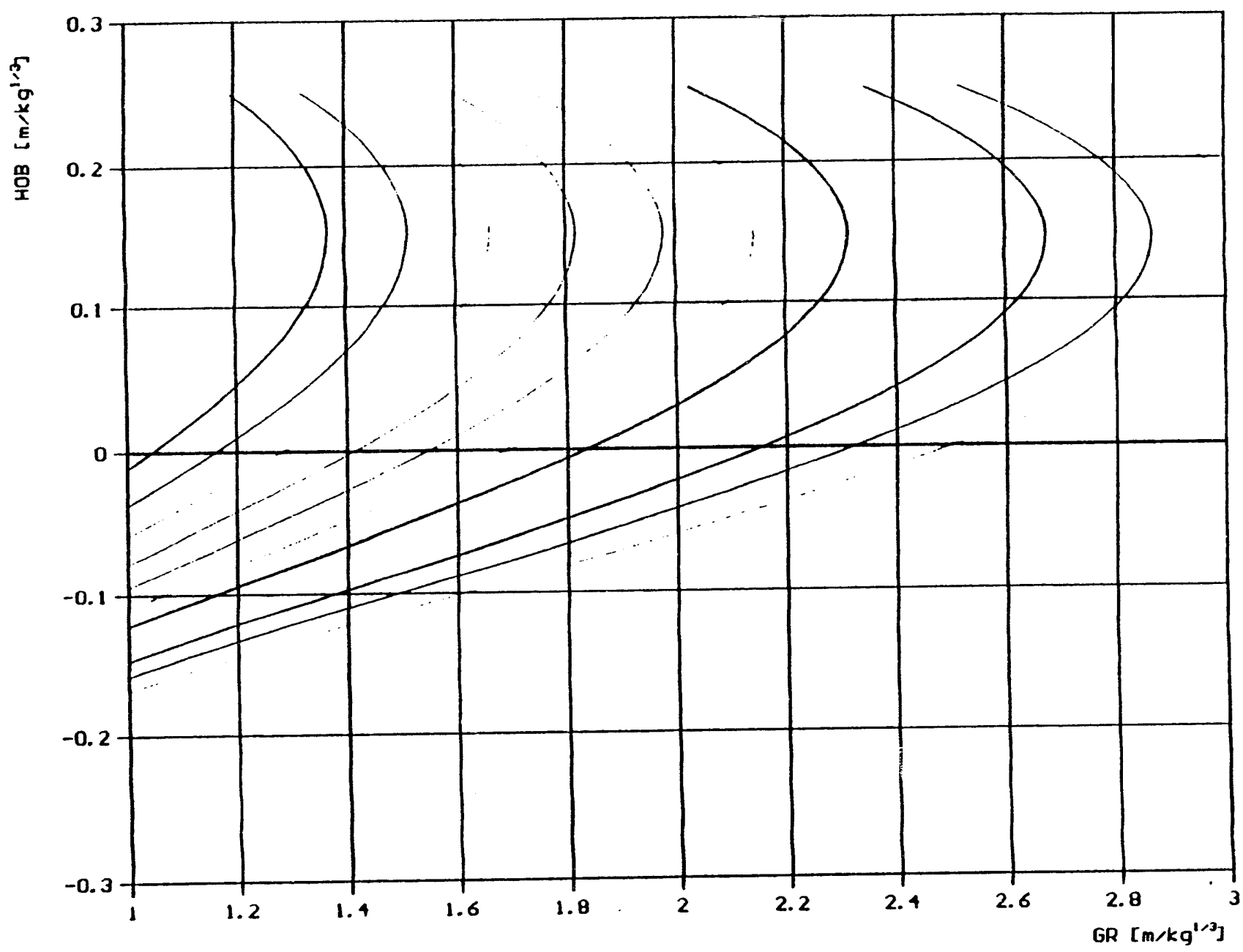

$T_{+}=0.001\left[\sec / \mathrm{kg}^{1 / 3}\right]$

$\ldots T_{+}=0.0011\left[\sec / \mathrm{kq}^{1 / 3}\right]$

$T+=0.0012\left[\sec / \mathrm{kg}^{1 / 3}\right]$

$T_{+}=0.0013\left[\mathrm{sec} / \mathrm{kq}^{1 / 3}\right]$

$T_{+}=0.0014\left[\sec / \mathrm{kg}^{1 / 3}\right]$

$I+=0.0015\left[\sec / k^{i / 3}\right]$

$-T_{+}=0.0016\left[\mathrm{sec} / \mathrm{kq}^{1 / 3}\right]$

$T_{+}=0.0017\left[\mathrm{sec} / \mathrm{kg}^{1 / 3}\right]$

$-T_{+}=0.0018\left[\sec / \mathrm{kg}^{1 / 3}\right]$

$-T+=0.0019\left[\sec / \mathrm{kq}^{1 / 3}\right]$

$T+=0.002\left[\sec / \mathrm{kg}^{1 / 3}\right]$

Figure 45c. Constant duration DOB curves for clay/loam

Polynomial approximation 

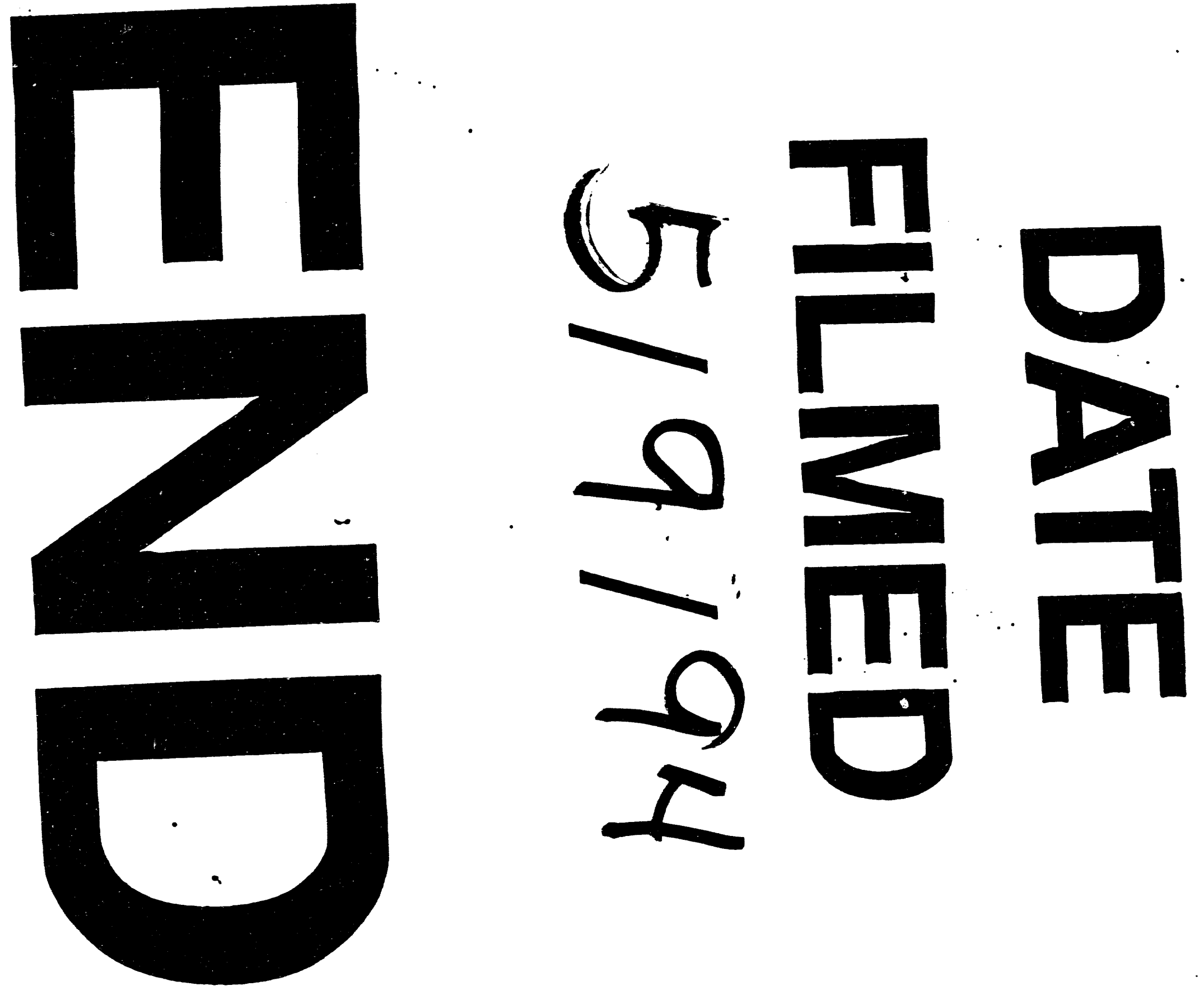